\begin{tabular}{l|l|l} 
u.s. Department of & Energy Efficiency \& \\
Renewable Energy
\end{tabular}

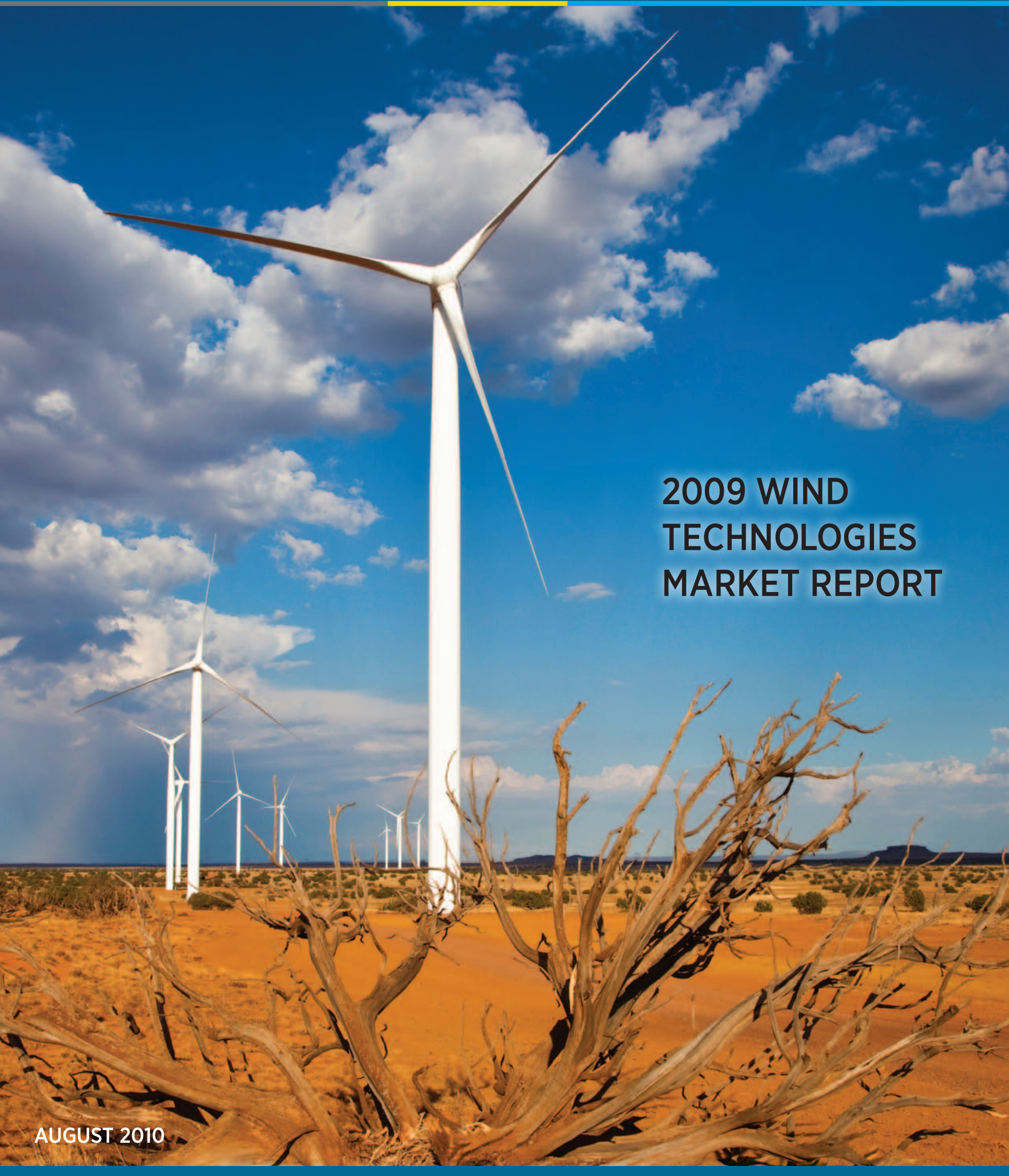




\title{
2009 Wind Technologies Market Report
}

\author{
Primary authors \\ Ryan Wiser, Lawrence Berkeley National Laboratory \\ Mark Bolinger, Lawrence Berkeley National Laboratory \\ With contributions from \\ Galen Barbose, Naïm Darghouth, Ben Hoen, and Andrew Mills (Berkeley Lab) \\ Kevin Porter and Sari Fink (Exeter Associates) \\ Suzanne Tegen (National Renewable Energy Laboratory)
}

\section{Table of Contents}

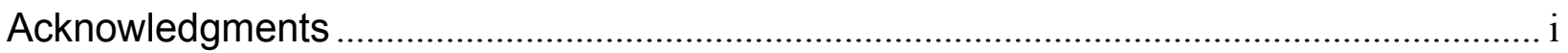

List of Acronyms ..................................................................................................................... ii

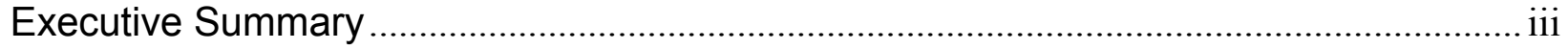

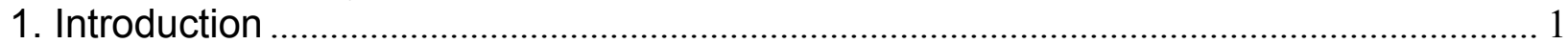

2. Installation Trends ........................................................................................................ 3

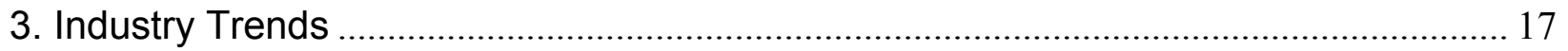

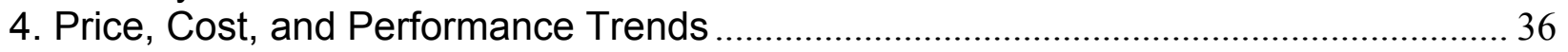

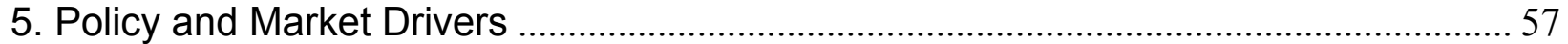

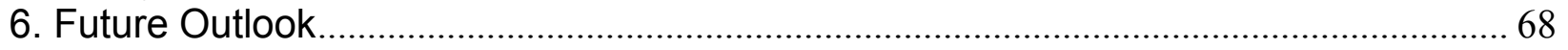

Appendix: Sources of Data Presented in this Report............................................ 71

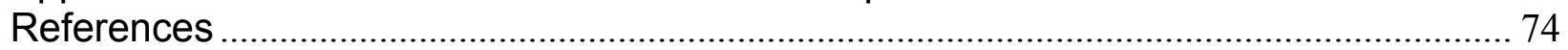

\section{Acknowledgments}

For their support of this project, the authors thank Jacques Beaudry-Losique, Megan McCluer, Jim Ahlgrimm, Michele Desautels, and Patrick Gilman of the U.S. Department of Energy's (DOE) Wind \& Water Power Program. For reviewing elements of this paper, we thank: Michael Goggin, Ron Stimmel, Liz Salerno, Jessica Isaacs, and Kathy Belyeu (AWEA); Brendan Kirby (consultant); Charlie Smith (UWIG); Jason Gifford and Bob Grace (Sustainable Energy Advantage); Andrew David (U.S. International Trade Commission); Jacques Beaudry-Losique, Liz Hartman, Jim Ahlgrimm, Brian Naughton, Patrick Gilman, and Ron Harris (DOE); Roger Hill (Sandia National Laboratory); Bob Thresher and Maureen Hand (NREL); James Browning (BCS, Inc.); Chris Namovicz (Energy Information Administration); Jennifer States (PNNL); Adam Hanna and Ric O'Connell (Black \& Veatch); Jim Walker (enXco); Doug Larson (Western Governors' Association); Ed DeMeo (Renewable Energy Consulting Services, Inc.); Mike O’Sullivan (NextEra Energy Resources); Steve Clemmer and Alan Nogee (Union of Concerned Scientists). Special thanks to the American Wind Energy Association (Kathy Belyeu and Elizabeth Salerno) for the use of their database of wind power projects, and for providing other data as discussed in the Appendix. We also thank Andrew David (U.S. International Trade Commission), Frank Oteri (NREL), and Billy Roberts (NREL) for their contributions to the wind equipment manufacturing sections; Walt Musial (NREL) as well as Bonnie Ram and Wendy Wallace (Energetics) for their assistance with the offshore wind energy discussion; Donna Heimiller (NREL) for the wind power project map; and Michelle Kubik and Kathleen O'Dell (NREL) for assistance with layout, formatting, and production. Berkeley Lab's contributions to this report were funded by the Wind \& Water Power Program, Office of Energy Efficiency and Renewable Energy of the U.S. Department of Energy under Contract No. DE-AC02-05CH11231. The authors are solely responsible for any omissions or errors contained herein. 


\section{List of Acronyms}

AWEA American Wind Energy Association

BPA Bonneville Power Administration

CCGT combined cycle gas turbine

COD commercial operation date

CREB clean renewable energy bond

CREZ competitive renewable energy zone

DOE U.S. Department of Energy

EIA Energy Information Administration

ERCOT Electric Reliability Council of Texas

EWITS Eastern Wind Integration and Transmission Study

FAA Federal Aviation Administration

FERC Federal Energy Regulatory Commission

GE General Electric Corporation

GW gigawatt

G\&T generation and transmission

HTS Harmonized Tariff Schedule

ICE IntercontinentalExchange

IOU investor-owned utility

IPP independent power producer

IREC Interstate Renewable Energy Council

IRS Internal Revenue Service

ISO independent system operator

ITC investment tax credit

$\mathrm{kW} \quad$ kilowatt

kWh kilowatt-hour

LADWP Los Angeles Department of Water \& Power

LIBOR London Interbank Offered Rate

MISO Midwest Independent System Operator
MMS Minerals Management Service

MNDOC Minnesota Department of Commerce

MSR Modesto-Santa Clara-Redding Public Power Agency

MW megawatt

MWh megawatt-hour

NERC North American Electric Reliability Corporation

NREL National Renewable Energy Laboratory

OEM original equipment manufacturer

O\&M operations and maintenance

POU publicly owned utility

PPA power purchase agreement

PTC Production Tax Credit

PUC public utility commission

PUCT Public Utility Commission of Texas

REAP Rural Energy for America Program

REC renewable energy certificate

RFI request for information

RPS renewables portfolio standard

RTO regional transmission organization

SPP Southwest Power Pool

TVA Tennessee Valley Authority

USDA United States Department of Agriculture

USITC U.S. International Trade Commission

UWIG Utility Wind Integration Group

WAPA Western Area Power Administration

WWSIS Western Wind and Solar Integration Study 


\section{Executive Summary}

Despite grim predictions at the close of 2008, the U.S. wind power industry experienced yet another record year in 2009, once again surpassing even optimistic growth projections from years past. At the same time, the combination of the financial crisis and lower wholesale electricity prices has taken a toll on the wind power industry, dampening expectations for 2010. Key findings from this year's "Wind Technologies Market Report” include:

- Wind Power Additions in 2009 Shattered Old Records, with roughly 10 GW of New Capacity Added in the United States and \$21 Billion Invested. The pace of utility-scale wind power capacity additions in 2009 was $20 \%$ higher than the previous U.S. record set in 2008 , while cumulative wind power capacity grew by $40 \%$. This was achieved despite the financial crisis that roiled the wind power industry in 2009 , and the significant reductions in wholesale electricity prices that began in mid- to late-2008 and have continued to the present. A variety of market drivers allowed year-on-year installation growth to persist in 2009 , including: carryover of projects initially planned for completion in 2008; elements of the American Recovery and Reinvestment Act of 2009 (Recovery Act), including the Section 1603 Treasury Grant Program; the expiration of bonus depreciation rules at the end of 2009; and state renewables portfolio standards.

- Wind Power Contributed 39\% of All New U.S. Electric Generating Capacity in 2009. This is down from $44 \%$ in 2008 , but exceeds wind power's contribution of $35 \%$ in 2007 , $18 \%$ in $2006,12 \%$ in 2005 , and less than $4 \%$ from 2000 through 2004 . For the fifth consecutive year, wind power was the second-largest new resource added to the U.S. electrical grid in terms of nameplate capacity, behind natural gas plants, but ahead of new coal power.

- The United States Continued to Lead the World in Cumulative Wind Power Capacity, but Was Overtaken by China in Annual Additions. After four years of leading the world in annual wind power capacity additions, the United States dropped to second place in 2009, capturing roughly $26 \%$ of the worldwide market (behind China's $36 \%$ market share). At the end of 2009, cumulative wind power capacity in the United States stood at more than 35,000 MW, ahead of China's 25,853 MW and Germany's 25,813 MW. Several countries are beginning to achieve relatively high levels of wind energy penetration in their electricity grids: end-of-2009 wind power capacity is projected to supply the equivalent of roughly $20 \%$ of Denmark's electricity demand, 14\% of Spain's and Portugal's, 11\% of Ireland's, and 8\% of Germany's. In the United States, the cumulative wind power capacity installed at the end of 2009 would, in an average year, be able to supply roughly $2.5 \%$ of the nation's electricity consumption.

- Texas Achieved Higher Annual Capacity Additions than Other States, While Four States Have Surpassed 10\% Wind Energy Penetration. With 2,292 MW installed in 2009 alone, Texas dominated the 28 other states in which new large-scale wind turbines were installed in 2009 (the next highest were Indiana with $905 \mathrm{MW}$ and Iowa with $879 \mathrm{MW}$ ). In terms of estimated wind energy supply as a proportion of in-state electricity generation, the front-runners include Iowa (19.7\%), South Dakota (13.3\%), North Dakota (11.9\%), and Minnesota (10.7\%). Some utilities are seeing higher percentages of wind energy supply than these state totals, with nine utilities estimated to have in excess of $10 \%$ wind energy on their systems. 
- Offshore Wind Power Project and Policy Developments Accelerated in 2009. To date, all wind power installations in the United States have been located on land, but there is also interest in offshore wind power development and 2,476 MW of offshore projects have advanced significantly in the permitting and development process. Of those projects, three have signed or proposed power purchase agreements with terms and details have been made public. Notably, after nine years in the permitting process, the Cape Wind project was granted approval by the Department of Interior in April 2010, and a variety of other recent project and policy announcements demonstrate accelerated activity in the offshore wind energy sector.

- Data from Interconnection Queues Demonstrate that an Enormous Amount of Wind Power Capacity Is Under Consideration. At the end of 2009, there were roughly $300 \mathrm{GW}$ of wind power capacity within the transmission interconnection queues administered by independent system operators, regional transmission organizations, and utilities reviewed for this report - nearly nine times the installed wind power capacity. This wind power capacity represented almost $60 \%$ of all generating capacity within these queues at that time, and was nearly three times as much capacity as the next-largest resource (natural gas). Most (93\%) of this wind power capacity is planned for the Midwest, Mountain, Texas, PJM, SPP, and Northwest regions. Not all of this capacity will ultimately be built as planned, but these data demonstrate the high level of developer interest in wind power.

- GE Remained the Top Turbine Manufacturer in the United States Market, but a Growing Number of Other Manufacturers Are Capturing Market Share. GE secured $40 \%$ of U.S. market share (by capacity) in 2009, followed by Vestas (15\%), Siemens (12\%), Mitsubishi (8\%), Suzlon (7\%), Clipper and Gamesa (6\% each), REpower (3\%), Acciona $(2 \%)$, and Nordex (1\%). Manufacturers with modern wind turbines installed in the United States now hail from not just the United States, Europe, and Japan, but also from India and, for the first time in 2009, China. In 2009, U.S.-owned GE was the second-leading supplier of turbines globally, while Clipper was the 13th largest global supplier. On a worldwide basis, perhaps the most significant story of 2009 was the growing market share of Chinese turbine manufacturers; to date, that growth has been based almost entirely on sales to the Chinese market, but Chinese manufacturers began to express strong interest in the U.S. market in 2009.

- Domestic Wind Turbine and Component Manufacturing Investments Remained Strong in 2009, but the Financial Crisis and Weak Turbine Sales Slowed the Sector's Growth. Seven of the ten wind turbine manufacturers with the largest share of the U.S. market in 2009 now have one or more manufacturing facilities operating in the United States, and two of the remaining three have announced specific plans to open facilities in the future. These figures compare to just one utility-scale wind turbine manufacturer (GE) assembling nacelles in the United States in 2004. In addition, a considerable number of new component manufacturing facilities were either announced or opened in 2009, by both foreign and domestic firms. Nevertheless, weak demand for new wind turbine orders and the poor state of the U.S. economy led to a net loss of 1,500 wind turbine and component manufacturing jobs in 2009, according to the American Wind Energy Association (AWEA). As a result, AWEA estimates that overall U.S. employment in the wind energy sector held steady at 85,000 fulltime jobs in 2009; of these, 18,500 are estimated by AWEA to be turbine and component manufacturing jobs. 
- A Growing Percentage of the Equipment Used in U.S. Wind Power Projects Has Been Sourced Domestically in Recent Years. U.S. trade data show that the United States remained a large importer of wind power equipment in 2009, but that wind power capacity growth has outpaced the growth in imports in recent years. As a result, a growing amount of the equipment used in wind power projects is being sourced domestically as domestic and foreign companies seek to minimize transportation costs and currency risks by establishing local manufacturing capabilities. Imports of wind turbines and select components in 2009 are estimated at $\$ 4.2$ billion, down from $\$ 5.4$ billion in 2008 . When presented as a fraction of total equipment-related wind turbine costs, the overall import fraction is estimated to have declined from roughly $50 \%$ in 2008 to $40 \%$ in 2009 as domestic manufacturing investments outpaced import growth.

- The Average Nameplate Capacity, Hub Height, and Rotor Diameter of Installed Wind Turbines Increased. The average nameplate capacity of wind turbines installed in the United States in 2009 increased to roughly 1.74 MW, up from 1.66 MW in 2008 and 1.65 MW in 2007. Since 1998-99, average turbine nameplate capacity has increased by $145 \%$, but growth in this metric has slowed in recent years due to the dominance of GE's $1.5 \mathrm{MW}$ turbine and as a result of the logistical challenges associated with transporting larger turbines to project sites. In addition to nameplate capacity ratings, average hub heights and rotor diameters have also scaled with time, to 78.8 and 81.6 meters, respectively, in 2009. Since 1998-99, the average turbine hub height has increased by $40 \%$, while the average rotor diameter has increased by 69\%: these trends are one of several factors impacting the projectlevel capacity factors highlighted later.

- The Average Size of Wind Power Projects Resumed its Upward Trend. Wind power projects installed in 2009 averaged nearly $91 \mathrm{MW}$, which is below the $120 \mathrm{MW}$ average size of projects built in 2007, but is otherwise larger than in any previous period. Larger project sizes reflect an increasingly mature energy source that is beginning to penetrate into the domestic electricity market in a significant way.

- Consolidation Among Wind Project Developers Continues. At least six significant acquisition or investment transactions involving roughly $18 \mathrm{GW}$ of in-development wind power projects were announced in 2009, compared to the five transactions and $19 \mathrm{GW}$ in 2008. This is well below the 11 transactions and $37 \mathrm{GW}$ in 2007, and the 12 transactions and $34 \mathrm{GW}$ in 2006. The more-subdued pace of activity since 2007 may be due to the fact that many of the prime targets for investment and/or acquisition were acquired in earlier years. In addition, some traditional buyers of wind assets may have decided to reign in new investments following aggressive purchases made in previous years, while some developers who might otherwise entertain offers may be holding out for better pricing as the market recovers. Looking ahead, the relatively weak demand for wind energy projected in 2010, coupled with an influx of cash from the Section 1603 Treasury grant program, may help to drive continued consolidation.

- Treasury Cash Grant Expands Financing Options, Buoys the Wind Sector. To reduce the market's dependence on scarce and costly third-party tax equity, Section 1603 of the Recovery Act enables wind power projects to temporarily choose a $30 \%$ cash grant administered by the U.S. Treasury in lieu of either the production tax credit (PTC) or a $30 \%$ investment tax credit (ITC). Owners of more than 6,400 MW of the wind power capacity installed in 2009 elected the grant in lieu of the PTC, and as much as 2,400 MW of this capacity may not have been built in 2009 had the cash grant not been available. Only about 
seven of the more-than-sixty 2009 projects that elected the grant were financed using thirdparty tax equity; many of the rest substituted project-level term debt - which became increasingly available as 2009 progressed - in place of third-party tax equity.

- Private IPP Project Ownership Remained Dominant, but Utility Ownership Increased. Private independent power producers (IPPs) own $83 \%$ of all new wind power capacity installed in the United States in 2009, and also $83 \%$ of cumulative capacity. In a continuation of the trend begun several years ago, however, $16 \%$ of total wind power additions in 2009 are owned by electric utilities, who now own $15 \%$ of the cumulative wind power capacity in the United States. Community wind power projects account for the remaining $2 \%$ of both annual and cumulative capacity.

- Long-Term Contracted Sales to Utilities Remained the Most Common Sales Arrangement, but Merchant Plants Were Surprisingly Abundant in 2009. Investorowned utilities continued to be significant purchasers of wind power, with $36 \%$ of the new 2009 capacity and $44 \%$ of cumulative capacity selling power to these utilities under longterm contract. Publicly owned utilities purchased another $22 \%$ and $18 \%$, respectively. Surprisingly, given the tightening of credit requirements in the wake of the financial crisis, as well as sharply lower wholesale electricity prices, merchant/quasi-merchant projects were abundant in 2009 , accounting for $38 \%$ of all new capacity and $26 \%$ of the cumulative capacity. It is possible that many of these merchant projects may now be seeking longerterm power purchase contracts in order to gain increased revenue stability.

- Upward Pressure on Wind Power Prices Continued in 2009. Although some of the cost pressures facing the industry in recent years have eased, it will take time before relief flows through the project development pipeline to impact overall average wind power prices. As such, 2009 was another year of rising wind power prices. The capacity-weighted average 2009 sales price for bundled power and renewable energy certificates, based on projects in the sample built in 2009, was roughly \$61/MWh (in 2009 dollars), up from an average of $\$ 51 / \mathrm{MWh}$ for the sample of projects built in 2008, and nearly double the average of $\$ 32 / \mathrm{MWh}$ among projects built during the low point in 2002 and 2003. Among projects in the sample, those in Texas and the Heartland region have the lowest prices on average, while those in New England, California, and the East have the highest prices.

- Sharp Drop in Wholesale Electricity Prices Makes the Near-Term Economics of Wind Energy More Challenging. The increase in wind power prices in 2009, combined with the deep reduction in wholesale electricity prices (driven by lower natural gas prices), pushed wind energy from the bottom to the top of the wholesale electricity price range in 2009 . Although low natural gas prices are, in part, attributable to the recession-induced drop in energy demand, the discovery and early development of significant shale gas deposits has reduced expectations for increases in natural gas prices going forward. As a result, natural gas prices may not rebound to earlier levels as the economy recovers, putting the near-term comparative economic position of wind energy at some risk.

- The Installed Cost of Wind Power Projects Continued to Rise in 2009, but Reductions May Be on the Horizon. Among a large sample of wind power projects installed in 2009, reported installed costs had a capacity-weighted average of $\$ 2,120 / \mathrm{kW}$. This average increased by $\$ 170 / \mathrm{kW}(9 \%)$ from the weighted-average cost of $\$ 1,950 / \mathrm{kW}$ for projects installed in 2008 , and increased by $\$ 820 / \mathrm{kW}(63 \%)$ from the average cost of projects installed from 2001 through 2004. Installed costs may - on average - remain high for a period of time as developers continue to work their way through the dwindling backlog of 
turbines purchased in early 2008 at peak prices. There are expectations, however, that average costs will decline over time as the cost pressures (e.g., rising materials costs, the weak dollar, turbine and component shortages) that have challenged the industry in recent years ease. Differences in average installed costs among regions and by project size are also apparent in the data.

- Wind Turbine Prices Have Begun to Show Signs of Easing, but Remain High By Historical Standards. Since hitting a low point of roughly $\$ 700 / \mathrm{kW}$ in the $2000-2002$ timeframe, average wind turbine prices have increased by approximately $\$ 800 / \mathrm{kW}(>100 \%)$ through 2009. Though turbine price increases have been the rule for a number of years, evidence is beginning to emerge that those days have ended, at least temporarily. Although visibility of turbine transaction prices declined in 2009 as the financial crisis took its toll and developers sat on turbine supply frame agreements that exceeded near-term development plans, cost pressures have eased since mid-2008. As a result, estimates of turbine price declines of as much as $15 \%$, along with more favorable contract terms, have begun to emerge. These price reductions and improved terms can be expected, over time, to exert downward pressure on project costs and wind power prices.

- Wind Project Performance Has Generally Improved Over Time, but Has Leveled Off in Recent Years. Boosted primarily by higher hub heights and larger rotor diameters, cumulative sample-wide average capacity factors have, in general, gradually increased over time, from just over 24\% in 1999 to a high of nearly 34\% in 2008, before dropping back to $30 \%$ in 2009 . The drop in 2009 is, in part, attributable to a relatively poor wind resource year in many parts of the country along with increasing amounts of wind power curtailment. Curtailment was particularly high in Texas (home to more than one-quarter of the nation's wind power capacity), with $17 \%$ of all potential wind energy generation within the Electric Reliability Council of Texas (ERCOT) curtailed in 2009. The sample-wide average U.S. capacity factor of $30 \%$ in 2009 would have reached $32 \%$ if not for the curtailment experienced in ERCOT and the Midwest. Other factors that may have slowed the rate of capacity factor increase for projects installed in more recent years include an enhanced emphasis on lower-quality wind resource sites (due to transmission and siting constraints), moderation of the increase in average hub heights and rotor diameters, and some challenges with turbine reliability.

- Operations and Maintenance Costs Are Affected by the Age and Size of the Project, Among Other Factors. Despite limited data availability, it appears that projects installed more recently have, on average, incurred lower O\&M costs than older projects in their first couple of years in operation. Likewise, larger projects appear to experience lower O\&M costs than do smaller projects, and O\&M costs increase as projects age.

- The Federal Policy Landscape Is Now More Favorable to Wind Energy than at Any Other Time in the Past Decade. The Recovery Act of 2009 extended the PTC for wind energy through 2012, and also implemented a number of other policy changes, including an option to elect a 30\% cash grant or ITC in lieu of the PTC, the expansion and enhancement of a federal loan guarantee program managed by the U.S. Department of Energy (DOE), and a 30\% tax credit for investment in advanced energy manufacturing facilities. In addition, $\$ 2.2$ billion in new Clean Renewable Energy Bonds were allocated in 2009, and \$60 million in U.S. Department of Agriculture (USDA) funding was distributed in the form of grants and loan guarantees, in part to fund wind power projects located in rural areas. Nonetheless, federal policy towards wind energy remains uncertain after 2012. 
- State Policies Play a Significant Role in Directing the Location and Amount of Wind Power Development. From 1999 through 2009, 61\% of the wind power capacity built in the United States was located in states with RPS policies; in 2009, this proportion was $57 \%$. One new state (Kansas) established a mandatory RPS program in 2009, bringing the total to 29 states and Washington D.C. Utility resource planning requirements, voluntary customer demand for "green" power, state clean energy funds, and state and regional carbon reduction policies also play a role in supporting wind energy deployment.

- Despite Progress on Overcoming Transmission Barriers, Constraints Remain. Transmission development appears to be gaining some traction, but siting, planning, and cost allocation issues remain key barriers to transmission investment. In June 2010, the Federal Energy Regulatory Commission (FERC) issued a proposed transmission cost allocation rule aimed at easing planning and cost allocation barriers. States, grid operators, regional organizations, and the DOE continue to take proactive steps to encourage transmission investment to access remote renewable resources. Finally, progress was made in 2009 on a number of transmission projects that are designed, in part, to support wind power.

- Integrating Wind Energy into Power Systems Is Manageable, but Not Free of Costs, and Market Operators Are Implementing Methods to Accommodate Increased Penetration. Recent studies show that wind energy integration costs are below $\$ 10 / \mathrm{MWh}-$ and often below $\$ 5 / \mathrm{MWh}$ - for wind power capacity levels up to or exceeding $40 \%$ of the peak load of the system in which the wind power is delivered. Moreover, a number of strategies that can help to ease the integration of increasing amounts of wind energy including the use of larger balancing areas, the use of wind forecasts, and intra-hour scheduling - are being implemented by grid operators across the United States.

In conclusion, 2009 continued a string of record-breaking years for the U.S. wind power industry. Looking ahead, expectations are for a slower year in 2010, due to a combination of the financial crisis, lower wholesale electricity prices, and lower demand for renewable energy. Wind power capacity additions in 2009 were buoyed, in part, by projects that were initially slated to be completed in 2008 but that carried over into 2009 when the PTC was extended, somewhat masking the underlying challenges facing the sector. With the extension of federal incentives through 2012, there is less motivation to complete projects in 2010 (though many projects will likely start construction in 2010 in order to be eligible for the $30 \%$ Treasury cash grant). Industry analysts project a range from 5,500 MW to $8,000 \mathrm{MW}$ of wind power capacity likely to be installed in the United States in 2010 , a drop of $20-45 \%$ compared to the nearly $10,000 \mathrm{MW}$ installed in 2009. After a slower 2010, most predictions show market resurgence in 2011 and 2012, as the Recovery Act programs mature and as financing constraints ease. Beyond 2012, however, the picture is considerably less certain, due to the scheduled expiration of a number of federal policies at the end of that year, including the PTC, the ability to elect a $30 \%$ ITC in lieu of the PTC, and the ability to receive the 30\% Treasury cash grant for projects that initiated construction by the end of 2010 . 


\section{Introduction}

The U.S. wind power industry experienced yet another record year in 2009, once again surpassing even optimistic growth projections from years past. At the same time, 2009 was a year of upheaval, with the global financial crisis impacting the wind power industry and with federal policy changes enacted to push the industry towards continued aggressive expansion. The year 2010, meanwhile, is anticipated to be one of some retrenchment, with expectations for fewer wind power capacity additions than seen in 2009 .

The rapid pace of development and change within the industry has made it difficult to keep up with trends in the marketplace, yet the need for timely, objective information on the industry and its progress has never been greater. This report - the fourth in an ongoing annual series attempts to meet this need by providing a detailed overview of developments and trends in the United States wind power market, with a particular focus on 2009.

As with previous editions, this report begins with an overview of key installation-related trends: trends in wind power capacity growth, how that growth compares to other countries and generation sources, the amount and percentage of wind energy in individual states and serving specific utilities, and the quantity of proposed wind power capacity in various interconnection queues in the United States. Next, the report covers an array of wind power industry trends, including developments in turbine manufacturer market share, manufacturing and supply-chain investments, wind turbine and wind power project size, project financing developments, and trends among wind power developers, project owners, and power purchasers. The report then turns to a discussion of wind project price, cost, and performance trends. In so doing, it reviews the prices paid for wind power in the United States, and how those prices compare to short-term wholesale electricity prices. It also describes trends in installed wind power project costs, wind turbine transaction prices, project performance, and operations and maintenance expenses. Next, the report examines other policy and market factors impacting the domestic wind power market, including federal and state policy drivers, transmission issues, and grid integration. Finally, the report concludes with a preview of possible near-term market developments.

This fourth edition updates data presented in the previous editions, while highlighting key trends and important new developments from 2009. New to this edition is a discussion of trends in the hub height and rotor diameter of wind turbines installed in the United States, new data on wind turbine and component imports into and exports from the United States, an expanded discussion of offshore wind energy development, and data on wind power curtailment. The importance of the American Recovery and Reinvestment Act of 2009 (the Recovery Act) to wind energy in 2009 is reflected throughout the report. The report concentrates on larger-scale wind turbines, defined here as individual turbines or projects that exceed $100 \mathrm{~kW}$ in size. ${ }^{1}$ The U.S. wind power sector is multifaceted, however, and also includes smaller, customer-sited wind turbines used to power residences, farms, and businesses. Data on these latter applications are not the focus of this report, though a brief discussion on Small Wind Turbines is provided on page 4.

\footnotetext{
${ }^{1}$ The $100 \mathrm{~kW}$ cut-off between 'small' and 'large' wind turbines is, in part, justified by the fact that the U.S. tax code makes a similar distinction. AWEA (2010a) sometimes uses this distinction as well, but in other instances defines large wind turbines as including turbines above and equal to $100 \mathrm{~kW}$.
} 
Much of the data included in this report were compiled by Berkeley Lab, and come from a variety of sources, including the American Wind Energy Association (AWEA), the Energy Information Administration (EIA), and the Federal Energy Regulatory Commission (FERC). The Appendix provides a summary of the many data sources used in the report, and a list of specific references follows the Appendix. Data on 2009 wind power capacity additions in the United States are based on information provided by AWEA; methodological differences exist in the processing of those data, however, and the data presented here therefore varies somewhat relative to AWEA (2010a). ${ }^{2}$ In other cases, the data shown here represent only a sample of actual wind power projects installed in the United States; furthermore, the data vary in quality. As such, emphasis should be placed on overall trends, rather than on individual data points. Finally, each section of this document focuses on historical market information, with an emphasis on 2009; with the exception of the final section, the report does not seek to forecast future trends.

\footnotetext{
${ }^{2}$ For example, large wind turbines are defined in this report as exceeding $100 \mathrm{~kW}$, and by AWEA (2010a) as equal to and exceeding $100 \mathrm{~kW}$. In reporting annual and cumulative capacity additions, this report focuses on large turbines, whereas AWEA (2010a) sometimes also includes small wind turbines. Other methodological differences between AWEA (2010a) and this report are noted as appropriate in the pages that follow.
} 


\section{Installation Trends}

\section{Wind Power Additions in 2009 Shattered Old Records, with roughly 10 GW of New Capacity Added in the United States and \$21 Billion Invested}

The U.S. wind power market delivered another record-shattering year in 2009, with 9,994 MW of new capacity added, bringing the cumulative total to more than $35,000 \mathrm{MW}$ (Figure 1). ${ }^{3}$ This growth translates into nearly $\$ 21$ billion (real 2009 dollars) invested in wind power project installation in 2009, for a cumulative investment total of $\$ 66$ billion since the beginning of the 1980s. ${ }^{4}$

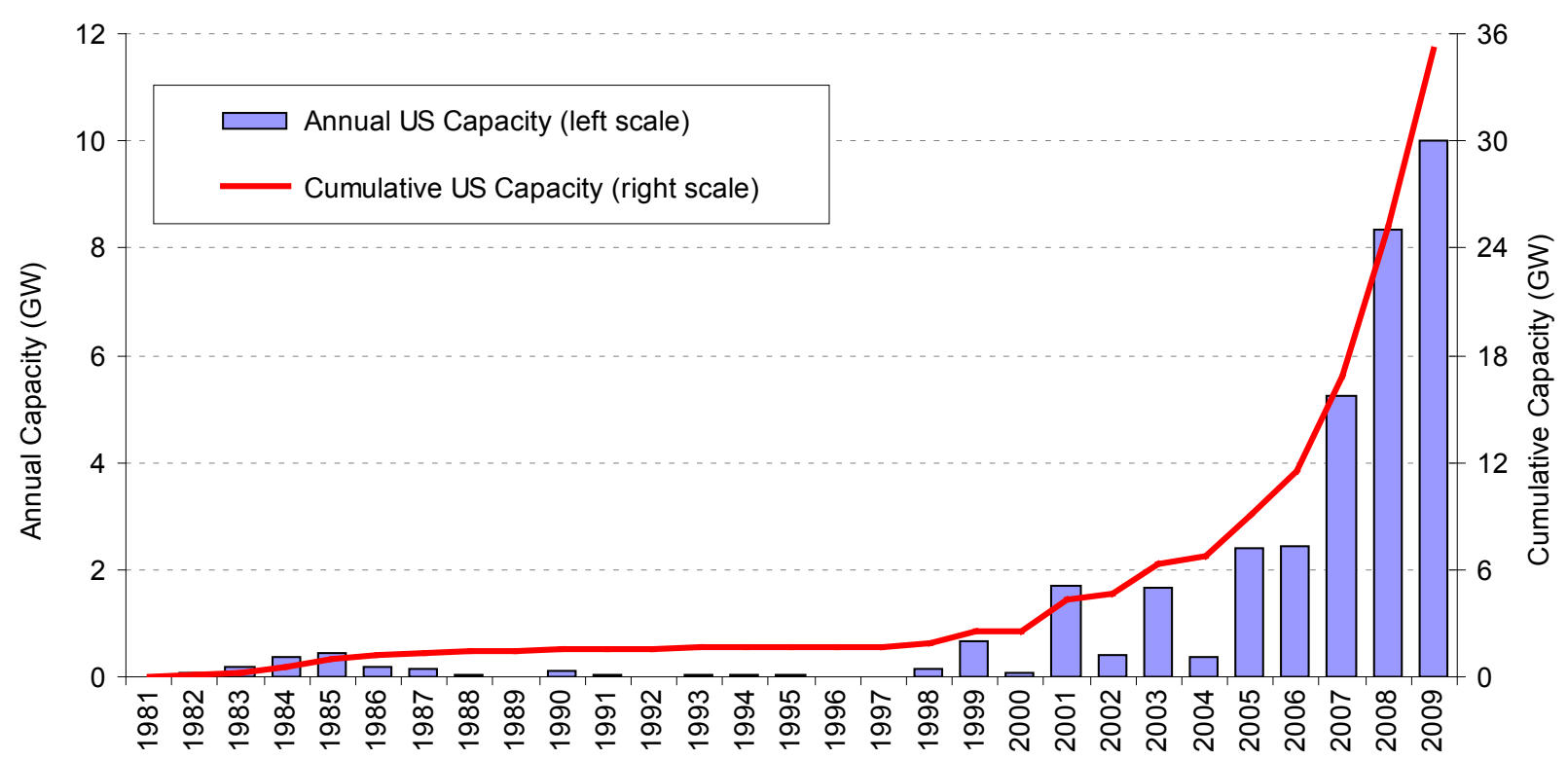

Source: AWEA project database

\section{Figure 1. Annual and Cumulative Growth in U.S. Wind Power Capacity}

Wind power installations in 2009 were not only the largest on record in the United States, but were $20 \%$ higher than the previous U.S. record, set in 2008. Cumulative wind power capacity grew by $40 \%$ in 2009 . This was achieved despite the financial crisis that roiled the wind power industry in 2009 , and the significant reductions in wholesale electricity prices that began in midto late-2008 and have continued to the present. A variety of market drivers allowed year-on-year installation growth to persist in 2009: carryover of projects initially planned for completion in 2008 (but, when the production tax credit was extended through 2012, ultimately came online in

\footnotetext{
${ }^{3}$ When reporting annual wind power capacity additions, this report focuses on gross capacity additions of large wind turbines. The net increase in capacity each year can be somewhat lower, reflecting turbine decommissioning. Some of the methodological differences between the figures presented here and by AWEA (2010a) are summarized in footnote 2. These difference lead AWEA (2010a) to report 10,010 MW of wind power capacity additions in 2009 (including large and small wind turbines), for a cumulative total of 35,086 MW

${ }^{4}$ These investment figures are based on an extrapolation of the average project-level capital costs reported later in this report, and do not include investments in manufacturing facilities, research \& development expenditures, or O\&M costs.
} 
2009); elements of the Recovery Act, including the Section 1603 Treasury Grant Program; the expiration of bonus depreciation rules at the end of 2009; state renewables portfolio standards (RPS); concerns about global climate change; and continued uncertainty about the future costs and liabilities of natural gas and coal facilities.

The yearly boom-and-bust cycle that characterized the U.S. wind power market from 1999 through 2004 - caused by periodic, short-term extensions of the federal production tax credit (PTC) - has now been replaced by five consecutive years of growth. With federal tax incentives for wind energy now extended through 2012, significant capacity additions and a semblance of near-term market stability might be expected. On the other hand, the global financial crisis, lower wholesale electricity prices, and lower demand for renewable energy have created expectations for a slower pace of wind power development in 2010. Moreover, wind power capacity additions in 2009 were buoyed, in part, by projects that were initially slated to be completed in 2008 but that carried over into 2009 when the PTC was extended, somewhat masking the underlying challenges facing the sector. With the extension of federal incentives through 2012, there is less motivation to complete projects in 2010.

\section{Small Wind Turbines}

Small wind turbines can provide power directly to homes, farms, schools, businesses, and industrial facilities, offsetting the need to purchase some portion of the host's electricity from the grid; such wind turbines can also provide power to off-grid sites. Wind turbines used in these applications are often much smaller - generally ranging in size from a few hundred watts to up to $100 \mathrm{~kW}$ or more - than the larger-scale turbines that are the primary focus of this report.

The table below summarizes sales of small wind turbines $100 \mathrm{~kW}$ and less in size into the U.S. market. As shown, more than $20 \mathrm{MW}$ of small wind turbines were sold in the U.S. in 2009; most of this new capacity came from turbines manufactured by U.S. companies. These installation figures represent a $15 \%$ growth in annual sales - in capacity terms - relative to 2008, yielding a cumulative installed capacity of small wind turbines in the United States in this turbine size range of roughly $100 \mathrm{MW}$. Within this market segment, there has been a trend towards larger, grid-tied systems (AWEA 2010b).

\begin{tabular}{|c|c|c|c|}
\hline \multirow{2}{*}{ Year } & \multicolumn{3}{|c|}{ Annual Sales of Small Wind Turbines into the United States } \\
\hline & Number of Turbines & Capacity Additions & Sales Revenue \\
\hline 2005 & 4,324 & $3.3 \mathrm{MW}$ & \$10 million \\
\hline 2006 & 8,329 & $8.6 \mathrm{MW}$ & $\$ 33$ million \\
\hline 2007 & 9,092 & $9.7 \mathrm{MW}$ & $\$ 42$ million \\
\hline 2008 & 10,386 & $17.4 \mathrm{MW}$ & \$73 million \\
\hline 2009 & 9,800 & $20.3 \mathrm{MW}$ & $\$ 82$ million \\
\hline
\end{tabular}

Source: AWEA (2010b)

Growth in this sector has been driven - at least in part - by a variety of state incentive programs. In addition, wind turbines equal to or under $100 \mathrm{~kW}$ in size are now eligible for an uncapped $30 \%$ investment tax credit (the $30 \%$ tax credit, with a dollar cap, was initially enacted in October 2008; the cap was removed in the Recovery Act of February 2009). 


\section{Wind Power Contributed 39\% of All New U.S. Electric Generating Capacity in 2009}

Wind power now represents one of the largest new sources of electric capacity additions in the United States. For the fifth consecutive year, wind power was the second-largest new resource added to the U.S. electrical grid in terms of aggregate capacity, behind the 11,500 MW of new natural gas plants added in 2009, but ahead of the 3,200 MW of new coal. New wind power projects contributed roughly $39 \%$ of the new nameplate capacity added to the U.S. electrical grid in 2009 , compared to $44 \%$ in $2008,35 \%$ in $2007,18 \%$ in $2006,12 \%$ in 2005 , and less than $4 \%$ from 2000 through 2004 (see Figure 2). ${ }^{5}$

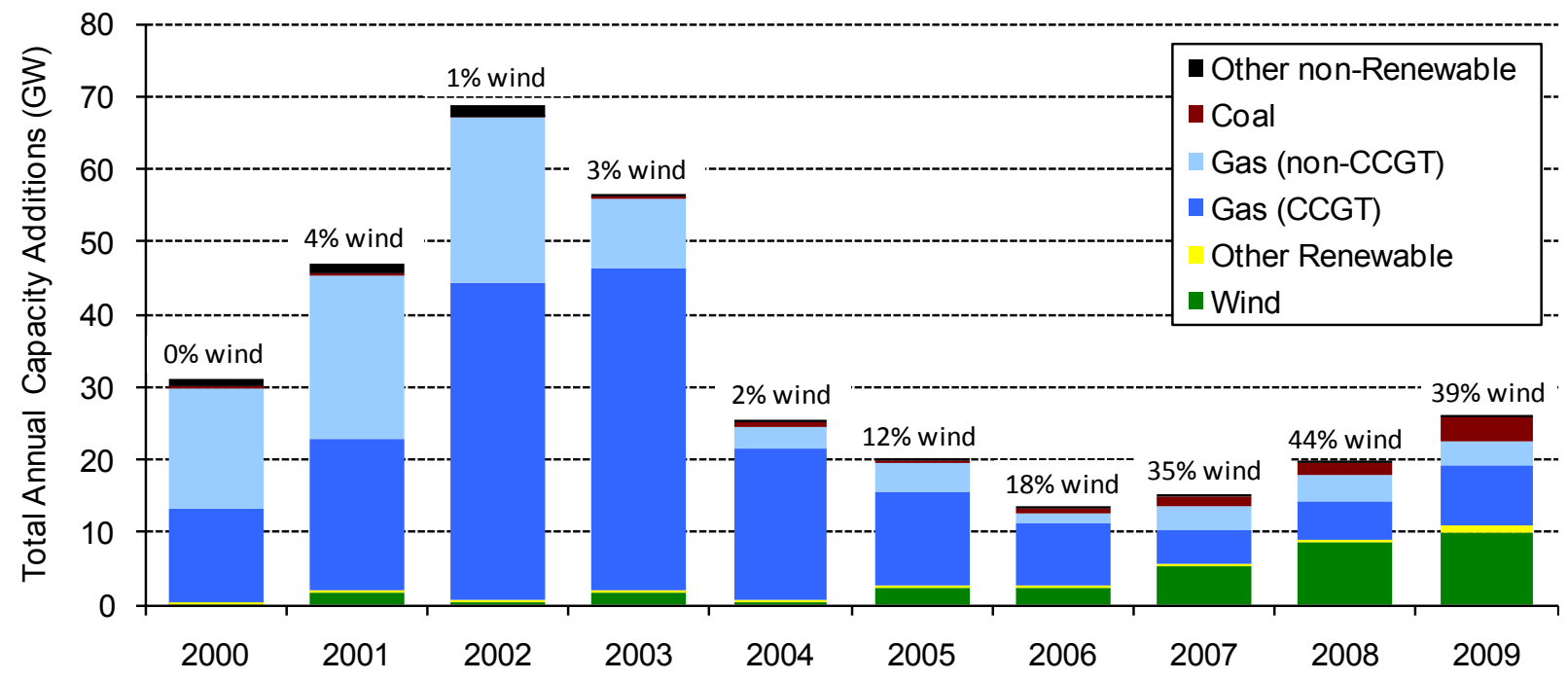

Source: EIA, Ventyx, AWEA, IREC, Berkeley Lab

\section{Figure 2. Relative Contribution of Generation Types in Annual Capacity Additions}

EIA's (2010) reference-case forecast projects that total U.S. electricity supply will need to increase at an average pace of roughly $49 \mathrm{TWh}$ per year from 2010 to 2035 in order to meet demand growth. On an energy basis, the annual amount of electricity expected to be generated by the new wind power capacity added in 2009 represents nearly $60 \%$ of this average annual projected growth in supply. ${ }^{6}$ By extension, if wind power additions continued through 2035 at the same pace as set in 2009 , then nearly $60 \%$ of the nation's projected increase in electricity generation from 2010 through 2035 would be met with wind electricity. Although future growth trends are hard to predict, it is clear that a significant portion of the country's new generation needs is already being met by wind.

\footnotetext{
${ }^{5}$ The same trend is apparent in Europe. In 2009, for example, more wind power was installed in the EU than any other generating technology, with $39 \%$ of all capacity additions coming from wind power (EWEA 2010). From 2000 through $2009,33 \%$ of capacity additions in the EU came from wind power, second only to natural gas.

${ }^{6}$ Given the relatively low capacity factor of wind power, one might initially expect that percentage contribution of wind power on an energy basis would be much lower than on a capacity basis. This is not necessarily the case, as documented by a review of capacity and electricity production data from EIA, in part because even though combined-cycle gas plants can be operated as baseload facilities with high capacity factors, those facilities are often run as intermediate plants with capacity factors that are not dissimilar from that of wind power. Combustion turbine gas facilities run at even lower capacity factors.
} 


\section{The United States Continued to Lead the World in Cumulative Wind Power Capacity, but Was Overtaken by China in Annual Additions}

On a worldwide basis, more than $38,000 \mathrm{MW}$ of wind power capacity was added in 2009 , the highest volume achieved in a single year, and up from about 28,000 MW in 2008, bringing the cumulative total to approximately $160,000 \mathrm{MW}$ (Table 1). In terms of cumulative installed wind power capacity, the United States ended the year with $22 \%$ of total worldwide capacity, and is the leading market in the world by this metric (Table 1 and Figure 3). Over the past 10 years, cumulative wind power capacity has grown an average of $30 \%$ per year in the United States, slightly higher than the $28 \%$ growth rate in worldwide capacity.

After four years of leading the world in annual wind power capacity additions, the U.S. dropped to second place in 2009 (Table 1), capturing roughly $26 \%$ of the worldwide market (behind China's 36\% market share ${ }^{7}$ ), down from $29 \%$ in 2008 and $27 \%$ in 2007 (Figure 3). Spain, Germany, and India rounded out the top five countries in 2009 for annual capacity additions. ${ }^{8}$

Table 1. International Rankings of Wind Power Capacity

\begin{tabular}{|l|r|l|r|}
\multicolumn{2}{c|}{$\begin{array}{c}\text { Annual Capacity } \\
\text { (2009, MW) }\end{array}$} & \multicolumn{2}{c|}{$\begin{array}{c}\text { Cumulative Capacity } \\
\text { (end of 2009, MW) }\end{array}$} \\
\hline China & 13,750 & U.S. & $\mathbf{3 5 , 1 5 5}$ \\
U.S. & $\mathbf{9 , 9 9 4}$ & China & 25,853 \\
Spain & 2,331 & Germany & 25,813 \\
Germany & 1,917 & Spain & 18,784 \\
India & 1,172 & India & 10,827 \\
Italy & 1,114 & Italy & 4,845 \\
France & 1,104 & France & 4,775 \\
U.K. & 1,077 & U.K. & 4,340 \\
Canada & 950 & Portugal & 3,474 \\
Portugal & 645 & Denmark & 3,408 \\
Rest of World & 4,121 & Rest of World & 22,806 \\
\hline TOTAL & $\mathbf{3 8 , 1 7 5}$ & TOTAL & $\mathbf{1 6 0 , 0 8 0}$ \\
\hline
\end{tabular}

Source: BTM Consult; AWEA project database for U.S. capacity

\footnotetext{
${ }^{7}$ Wind power additions in China are from BTM (2010), and include a considerable amount of capacity that was installed but that had not yet received transmission interconnection by the end of 2009 . All of the U.S. capacity reported here, on the other hand, was capable of electricity delivery. In fact, if only considering the new wind power capacity that achieved transmission interconnection and was therefore capable of delivering electricity to the grid by the end of 2009, the United States would have again led the world in annual capacity additions in 2009.

${ }^{8}$ Yearly and cumulative installed wind power capacity in the United States are from AWEA, while global wind power capacity in 2009 comes from BTM (2010), but updated with the most recent AWEA data for the United States. Global wind power capacity in earlier years comes from the Earth Policy Institute. Some disagreement exists among these data sources and others, e.g., Windpower Monthly and the Global Wind Energy Council.
} 


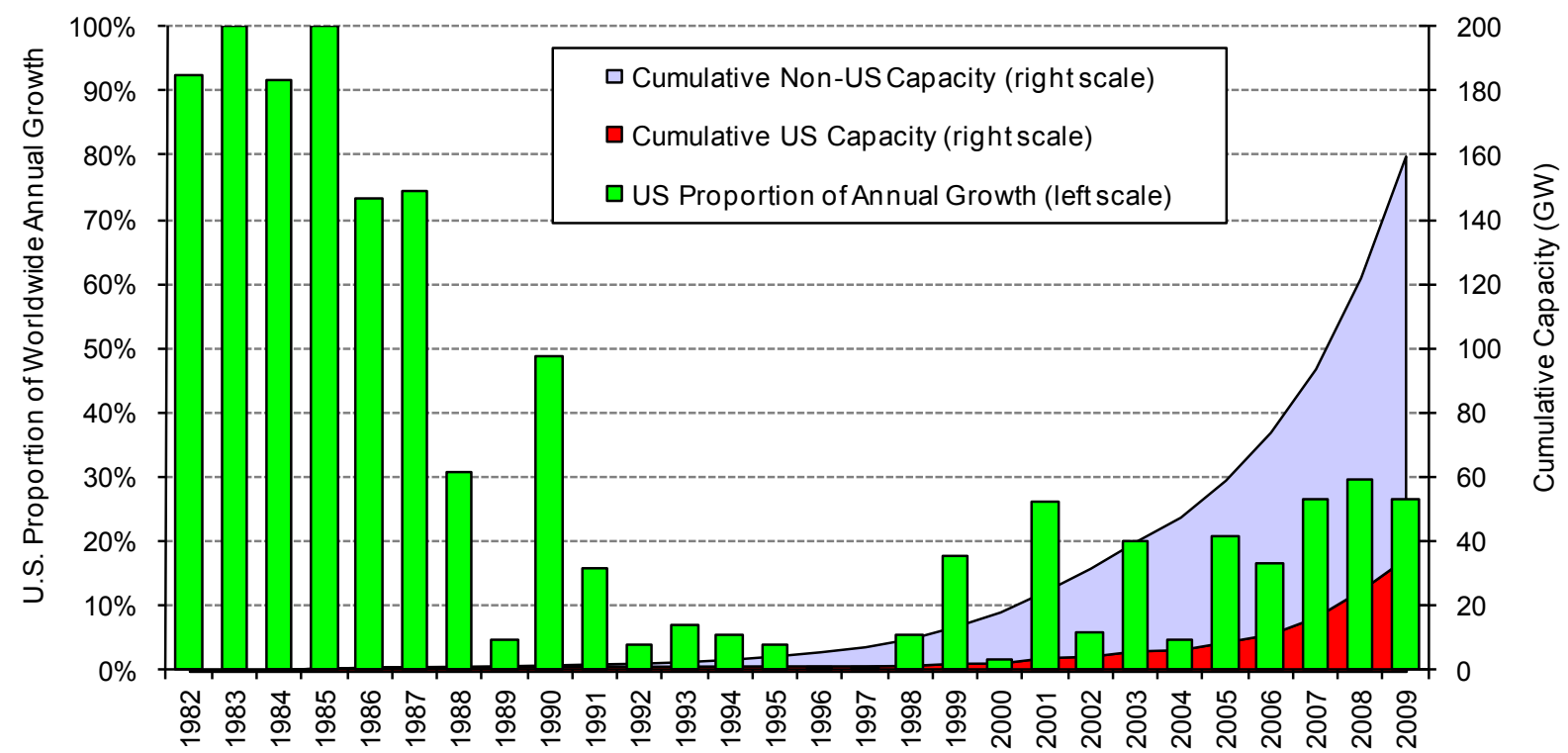

Source: Earth Policy Institute, BTM Consult, AWEA project database

Figure 3. The Contribution of U.S. Wind Power Capacity to Global Wind Power Capacity

Several countries are beginning to achieve relatively high levels of wind energy penetration in their electricity grids. Figure 4 presents data on end-of-2009 (and end-of-2006/07/08) installed wind power capacity, translated into projected annual electricity supply based on assumed country-specific capacity factors, and divided by projected 2010 (and 2007/08/09) electricity consumption. Using this approximation for the contribution of wind power to electricity consumption, and focusing only on the 20 countries with the greatest cumulative installed wind power capacity, end-of-2009 installed wind power is projected to supply the equivalent of roughly $20 \%$ of Denmark's electricity demand, $14 \%$ of Portugal's, $14 \%$ of Spain's, $11 \%$ of Ireland's, and $8 \%$ of Germany's. In the United States, the cumulative wind power capacity installed at the end of 2009 would, in an average year, be able to supply roughly $2.5 \%$ of the nation's electricity consumption (up from $1.8 \%$ at the end of 2008, $1.2 \%$ at the end of 2007, and $0.8 \%$ at the end of 2006). ${ }^{9}$ On a global basis, wind energy's contribution at the end of 2009 is estimated to be $1.8 \%$.

\footnotetext{
${ }^{9}$ In terms of actual 2009 deliveries, wind energy represented $1.8 \%$ of net electricity generation and $2.0 \%$ of national electricity consumption in the United States. These figures are below the $2.5 \%$ figure provided above because $2.5 \%$ is a projection based on end-of-year 2009 wind power capacity.
} 


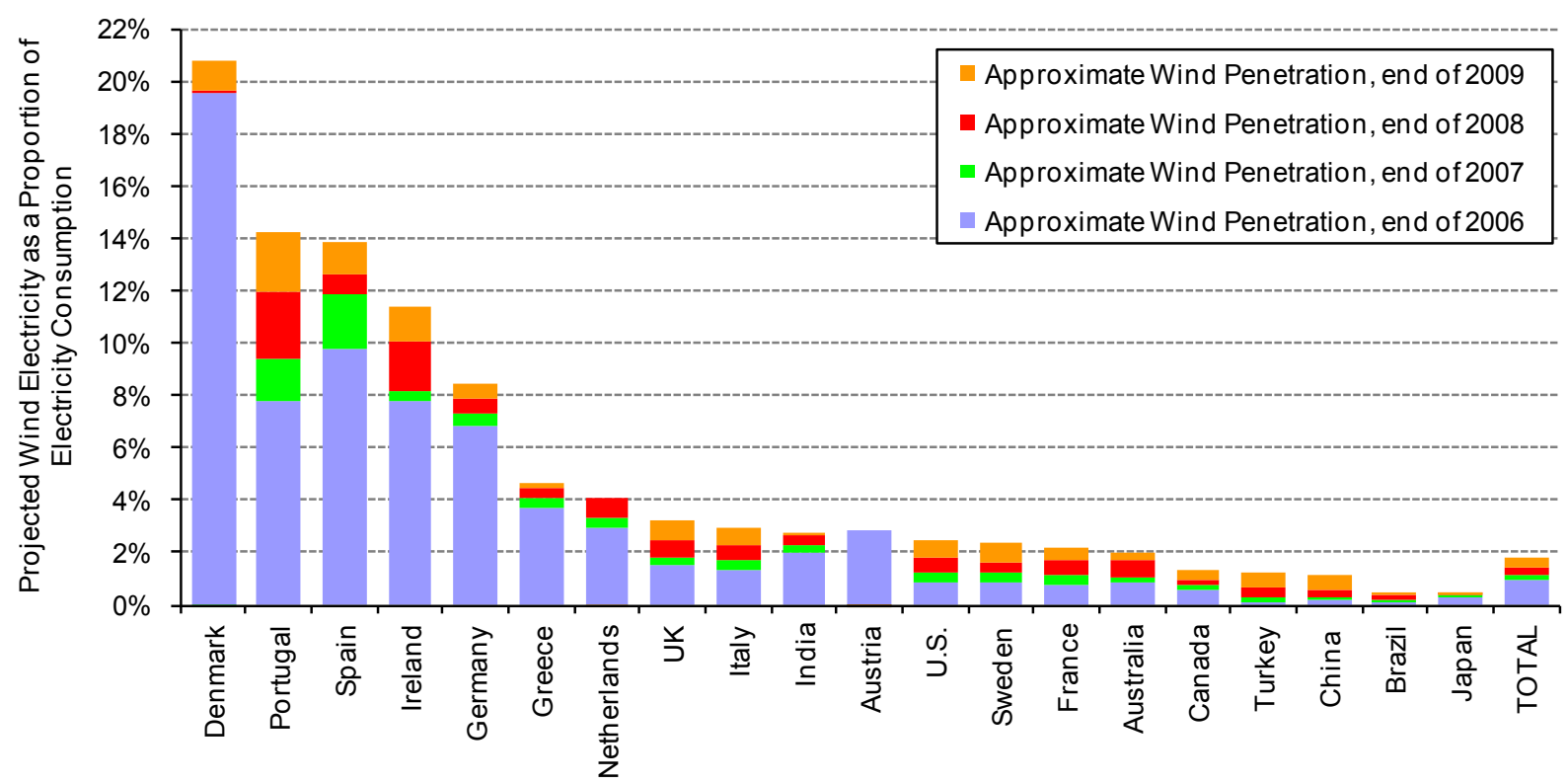

Source: Berkeley Lab estimates based on data from BTM Consult and elsewhere

Figure 4. Approximate Wind Energy Penetration in the Twenty Countries with the Greatest Installed Wind Power Capacity

\section{Texas Achieved Higher Annual Capacity Additions than Other States, While Four States Have Surpassed 10\% Wind Energy Penetration}

New large-scale ${ }^{10}$ wind turbines were installed in 29 states in 2009 . Texas again dominated in terms of new wind power capacity, with 2,292 MW installed in 2009 alone, down somewhat from 2,671 MW installed in 2008. As shown in Figure 5 and Table 2, other leading states in terms of new capacity (each with more than $500 \mathrm{MW}$ ) include Indiana, Iowa, Oregon, Illinois, New York, and Washington. Thirteen states added more than 200 MW each in 2009.

On a cumulative basis, Texas continued to build on its lead in 2009, with a total of 9,410 MW of wind power capacity installed by the end of the year. In fact, Texas has more installed wind power capacity than all but five countries worldwide. U.S. states following Texas in cumulative installed capacity are Iowa, California, Washington, and Oregon. Sixteen states had more than $500 \mathrm{MW}$ of wind power capacity as of the end of 2009, with fourteen topping 1,000 MW, and three topping 2,000 MW. Although all wind power projects in the United States to date have been installed on land, offshore development activities continued in 2009, as discussed in the next section.

\footnotetext{
10 "Large-scale" turbines are defined consistently with the rest of this report - i.e., turbines over $100 \mathrm{~kW}$.
} 


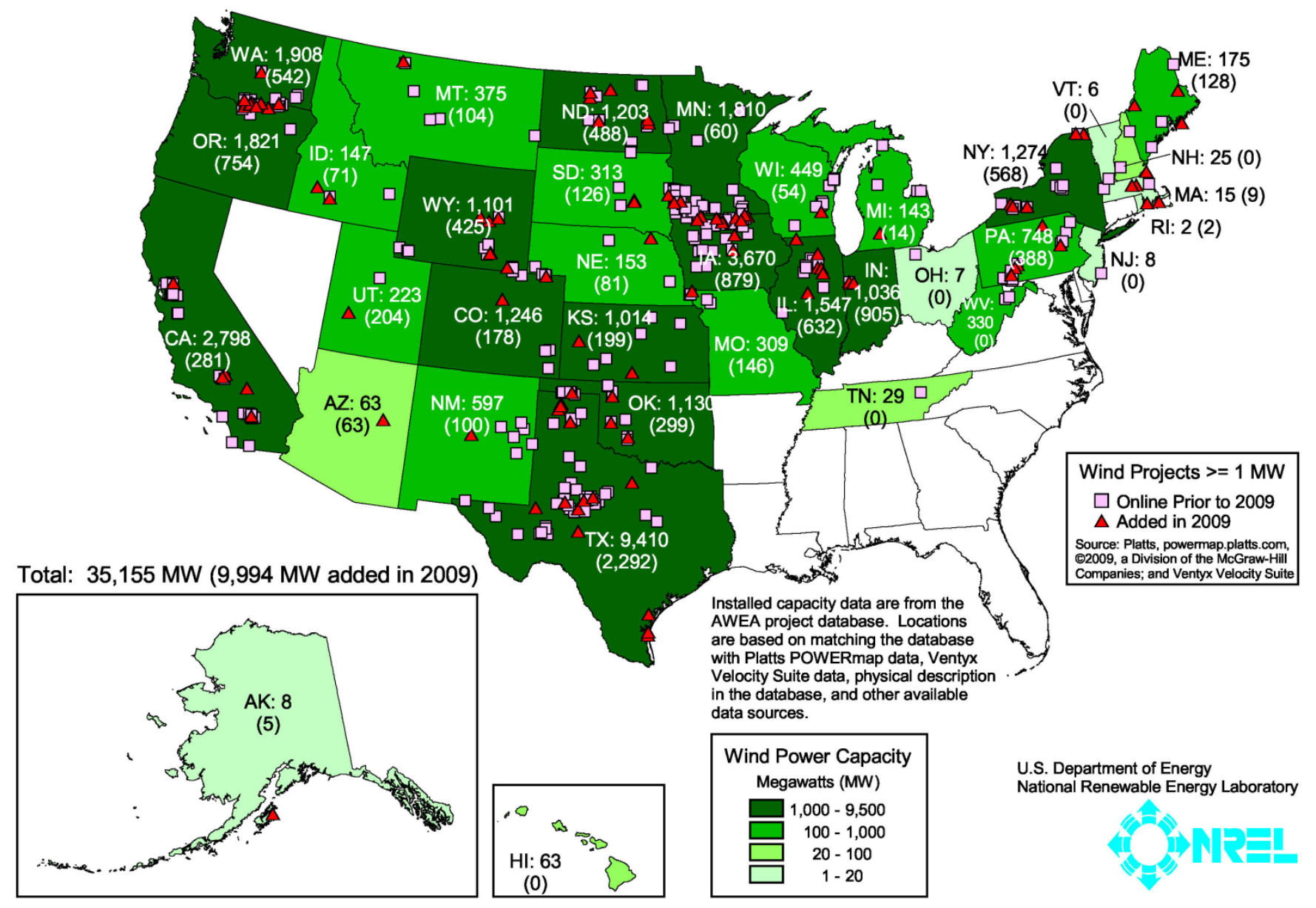

Note: Numbers within states represent cumulative installed wind capacity and, in parentheses, annual additions in 2009.

Figure 5. Location of Wind Power Development in the United States

Some states are beginning to realize relatively high levels of wind energy penetration. Table 2 lists the top 20 states based on an estimate of wind electricity generation from end-of-2009 wind power capacity, divided by total in-state electricity generation in 2009. ${ }^{11}$ By this metric, four Great Plains states lead the list in terms of estimated wind energy as a percentage of total in-state generation. Specifically, the wind power capacity installed as of the end of 2009 is estimated, in an average year, to be capable of generating approximately $19.7 \%$ of all in-state electricity

\footnotetext{
${ }^{11}$ Wind energy penetration can either be expressed as a percentage of in-state load or in-state generation. In-state generation is used here, primarily because wind energy is often sold across state lines, which tends to distort penetration levels expressed as a percentage of in-state load. To estimate these figures, end-of-2009 wind power capacity is translated into estimated annual wind electricity production based on estimated state-specific capacity factors that derive from the project performance data reported later in this report. The resulting state-specific wind electricity production estimates are then divided by the latest data on total in-state electricity generation available from the EIA (i.e., 2009). The resulting wind energy penetration estimates shown in Table 2 differ from what AWEA provides in its U.S. Wind Industry Annual Market Report (AWEA 2010a). The most significant source of these differences is that AWEA uses preliminary data on actual 2009 wind electricity generation from EIA, while this report estimates annual wind electricity generation based on the amount of wind power capacity installed at the end of 2009.
} 
generation in Iowa, $13.3 \%$ in South Dakota, 11.9\% in North Dakota, and 10.7\% in Minnesota. Five additional states surpass the $5 \%$ mark by this metric, while twenty states exceed $2 \%$.

\section{Table 2. United States Wind Power Rankings: The Top 20 States}

\begin{tabular}{|c|c|c|c|c|c|}
\hline \multicolumn{2}{|c|}{$\begin{array}{l}\text { Annual Capacity } \\
(2009, \text { MW })\end{array}$} & \multicolumn{2}{|c|}{$\begin{array}{l}\text { Cumulative Capacity } \\
\text { (end of 2009, MW) }\end{array}$} & \multicolumn{2}{|c|}{$\frac{\text { Estimated Percentage of }}{\text { In-State Generation* }}$} \\
\hline Texas & 2,292 & Texas & 9,410 & Iowa & $19.7 \%$ \\
\hline Indiana & 905 & Iowa & 3,670 & South Dakota & $13.3 \%$ \\
\hline Iowa & 879 & California & 2,798 & North Dakota & $11.9 \%$ \\
\hline Oregon & 754 & Washington & 1,908 & Minnesota & $10.7 \%$ \\
\hline Illinois & 632 & Oregon & 1,821 & Oregon & $9.0 \%$ \\
\hline New York & 568 & Minnesota & 1,810 & Colorado & $7.7 \%$ \\
\hline Washington & 542 & Illinois & 1,547 & Kansas & $7.4 \%$ \\
\hline North Dakota & 488 & New York & 1,274 & Texas & $6.8 \%$ \\
\hline Wyoming & 425 & Colorado & 1,246 & Wyoming & $6.7 \%$ \\
\hline Pennsylvania & 388 & North Dakota & 1,203 & Oklahoma & $5.0 \%$ \\
\hline Oklahoma & 299 & Oklahoma & 1,130 & Montana & $4.9 \%$ \\
\hline California & 281 & Wyoming & 1,101 & Washington & $4.9 \%$ \\
\hline Utah & 204 & Indiana & 1,036 & New Mexico & $4.6 \%$ \\
\hline Kansas & 199 & Kansas & 1,014 & California & $3.4 \%$ \\
\hline Colorado & 178 & Pennsylvania & 748 & Maine & $3.1 \%$ \\
\hline Missouri & 146 & New Mexico & 597 & Idaho & $3.0 \%$ \\
\hline Maine & 128 & Wisconsin & 449 & Indiana & $2.7 \%$ \\
\hline South Dakota & 126 & Montana & 375 & New York & $2.2 \%$ \\
\hline Montana & 104 & West Virginia & 330 & Hawaii & $2.2 \%$ \\
\hline New Mexico & 100 & South Dakota & 313 & Illinois & $2.1 \%$ \\
\hline Rest of U.S. & 358 & Rest of U.S. & 1,376 & Rest of U.S. & $0.3 \%$ \\
\hline TOTAL & 9,994 & TOTAL & 35,155 & TOTAL & $2.5 \%$ \\
\hline
\end{tabular}

* Based on a projection of wind electricity generation from end-of-2009 wind power capacity, divided by total instate electricity generation in 2009.

Source: AWEA project database, EIA, Berkeley Lab estimates

Some utilities are achieving even higher levels of wind energy penetration into their individual electric systems. Table 3 lists the top-20 utilities in terms of aggregate wind power capacity on their systems at the end of 2009, based on data provided by AWEA (2010a). Included here are wind power projects either owned by or under long-term contract with these utilities for use by their own customers; short-term renewable electricity and renewable energy certificate purchases are excluded. The table also lists the top-20 utilities based on an estimate of the percentage of retail sales that wind electricity represents, using end-of-2009 wind power capacity, wind power capacity factors that are consistent with the state or region in which a utility operates, and EIAprovided aggregate retail electricity sales for each utility in 2008. ${ }^{12}$ As shown, Minnkota Power

\footnotetext{
${ }^{12}$ In calculating these figures, several issues deserve mention. First, the utility-specific capacity data that AWEA released in its U.S. Wind Industry Annual Market Report (AWEA 2010a) are used, with two exceptions: (1) the Empire District Electric Company, with $255 \mathrm{MW}$ of wind power under contract at the end of 2009, was added to AWEA's "top twenty" investor-owned utility list at position number 14 (and ranks $19^{\text {th }}$ in our combined list of all utility types); and (2) Minnkota Power Cooperative's wind power capacity was corrected to 357 MW (AWEA (2010a) shows $290 \mathrm{MW}$ ). Second, only utilities with more than $100 \mathrm{MW}$ of wind power capacity are included in the calculation of wind energy as a proportion of retail sales. Third, projected wind generation based on each utility's installed wind power capacity at the end of 2009 is divided by the aggregate national retail sales of that utility in
} 
Cooperative is estimated to have achieved $38 \%$ wind energy penetration by this metric, while a total of nine utilities are estimated to have exceeded $10 \%$.

\section{Table 3. Top-20 Utility Wind Power Rankings}

\begin{tabular}{|l|l|l|l|}
\multicolumn{2}{c}{$\begin{array}{c}\text { Total Wind Capacity } \\
\text { (end of 2009, MW) }\end{array}$} & \multicolumn{2}{c|}{$\begin{array}{c}\text { Estimated Percentage of Retail Sales } \\
\text { (for utilities with > 100 MW of wind) }\end{array}$} \\
\hline Xcel Energy & 3,176 & Minnkota Power Cooperative & $38.0 \%$ \\
\hline MidAmerican Energy & 2,923 & Empire District Electric Company & $18.1 \%$ \\
\hline Southern California Edison & 1,772 & Turlock Irrigation District & $18.0 \%$ \\
\hline American Electric Power & 1,196 & Otter Tail Power & $14.0 \%$ \\
\hline Pacific Gas \& Electric & 1,131 & Sunflower Electric Power Corp. & $13.2 \%$ \\
\hline Luminant & 913 & Xcel Energy & $11.1 \%$ \\
\hline Alliant Energy & 645 & Austin Energy & $10.3 \%$ \\
\hline City Public Service of San Antonio & 579 & Great River Energy & $10.1 \%$ \\
\hline Puget Sound Energy & 479 & Westar & $10.1 \%$ \\
\hline Austin Energy & 439 & Western Farmers' Electric Cooperative & $9.8 \%$ \\
\hline First Energy & 376 & MidAmerican Energy & $9.6 \%$ \\
\hline Portland General Electric & 375 & Snohomish Public Utility District & $8.5 \%$ \\
\hline Minnkota Power Cooperative & 357 & MSR Public Power Agency & $8.4 \%$ \\
\hline Basin Electric & 352 & City Public Service of San Antonio & $8.4 \%$ \\
\hline SDG\&E & 342 & Public Service New Mexico & $6.8 \%$ \\
\hline Great River Energy & 319 & Cowlitz Public Utility District & $6.5 \%$ \\
\hline Westar & 295 & WPPI Energy & $6.4 \%$ \\
\hline Oklahoma Gas \& Electric & 272 & Alliant Energy & $5.9 \%$ \\
\hline Empire District Electric Company & 255 & Puget Sound Energy & $5.4 \%$ \\
\hline SCPPA (not including LADWP) & 233 & Northwestern Energy & $5.3 \%$ \\
\hline * Based on a projection of wind electricity generation from end-of-2009 wind power capacity, divided by the retail sales for each \\
\hline utility in 2008. \\
\hline Source: AWEA, ElA, Berkeley Lab estimates & & & \\
\hline & & & \\
\hline
\end{tabular}

2008 (which is the latest full year of utility-specific retail sales data provided by EIA). Fourth, in the case of generation and transmission (G\&T) cooperatives and power authorities that provide power to other cooperatives and municipal utilities (but do not directly serve retail load themselves), 2008 retail sales from the electric utilities served by those G\&T organizations and power authorities are used. In some cases, these individual utilities may be buying additional wind power directly from other projects, or may be served by other G\&T cooperatives or power authorities that supply wind. In these cases, the penetration percentages shown here may be somewhat misleading. As an example, the "MSR Public Power Agency" (MSR) is a joint powers agency created to procure power for municipal utilities in the California cities of Modesto, Santa Clara, and Redding. The $8.4 \%$ penetration rate shown in the second column of Table 3 represents MSR's power purchase agreement with the 200 MW Big Horn wind power project in Washington state. Two of the three municipal utilities participating in MSR, however, purchase additional wind energy from other wind power projects. The result is that if one were to look at these three municipal utilities individually rather than as a group through MSR, their penetration rates would be considerably higher than the $8.4 \%$ shown in Table 3. 


\section{Offshore Wind Power Project and Policy Developments Accelerated in 2009}

Offshore wind power projects totaling $689 \mathrm{MW}$ were installed globally in 2009, bringing worldwide offshore capacity to $2,110 \mathrm{MW}$ (BTM 2010). The vast majority of this capacity is located in Europe. In contrast, all wind power projects built in the United States to date have been sited on land. The availability of low-cost land-based wind energy, regulatory delays and uncertainty associated with offshore development, turbine supply shortages, high and uncertain offshore project costs, and public acceptance concerns have so far hampered progress in the offshore sector in the United States. Nonetheless, there is interest in offshore wind energy in several parts of the country, driven by the proximity of offshore wind resources to large population centers, advances in technology, potential local economic development benefits, and superior capacity factors (and, in some instances, peak load coincidence) compared to the finite set of attractive and developable land-based wind power projects available in some regions.

Figure 6 shows 13 proposed offshore wind power projects in the United States that have advanced significantly in the permitting and development process. These projects have either made substantial progress towards receiving state approval or have received a lease or "interim limited lease" from the U.S. Minerals Management Service (MMS). ${ }^{13}$ In total, these proposed projects equal 2,476 MW, and are primarily located in the Northeast and Mid-Atlantic, though notable proposed projects also exist in the Southeast, Great Lakes, and Gulf of Mexico. Even these "advanced stage" projects are in various stages of development - some or even many may never be realized, while other projects not identified in the figure are also under consideration.

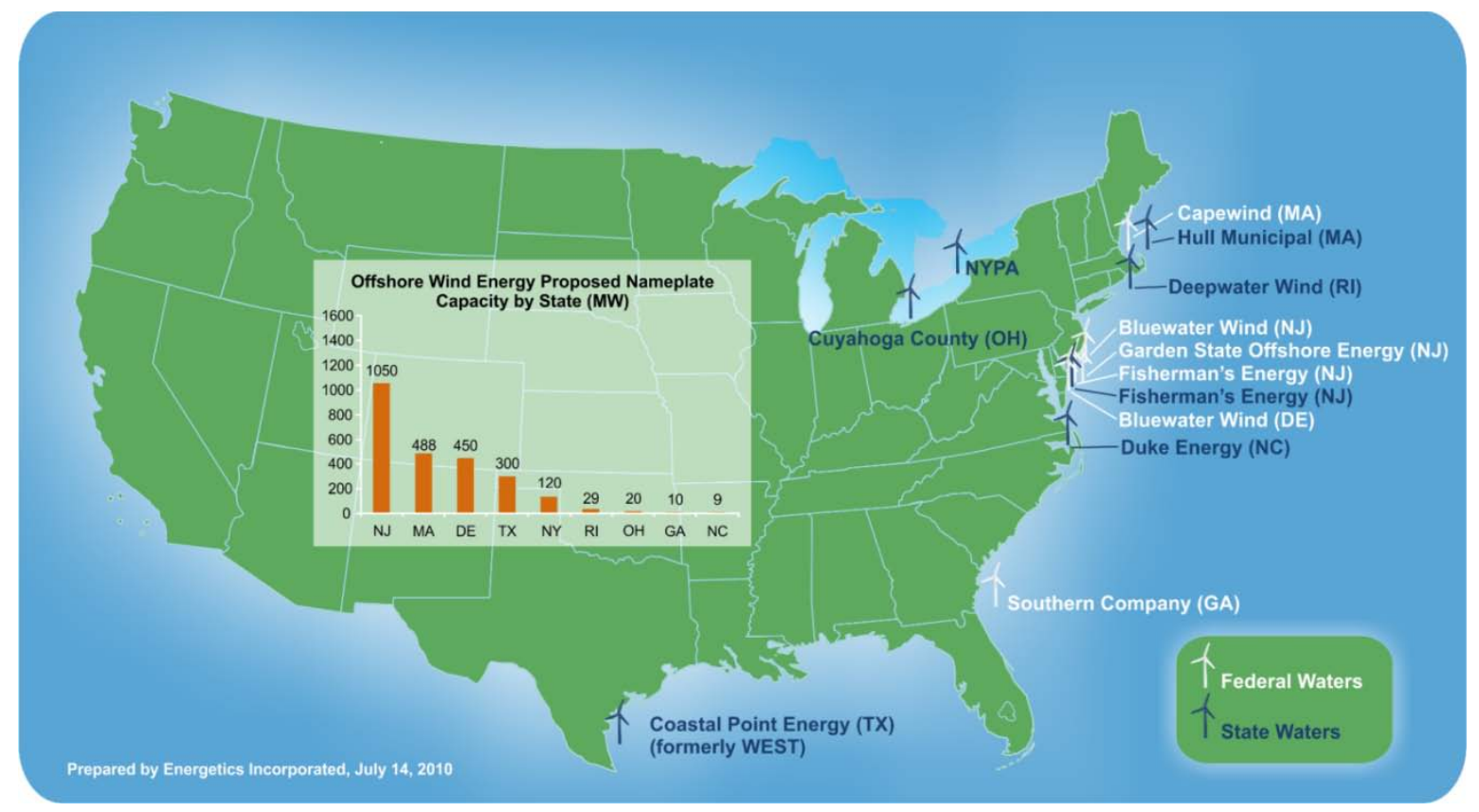

Source: Musial et al. (2010)

Figure 6. Offshore Wind Power Projects in a Relatively Advanced State of Development

\footnotetext{
${ }^{13}$ In June 2010, MMS was renamed the Bureau of Ocean Energy Management, Regulation, and Enforcement. For the purpose of this report, we continue to use the name that applied prior to June 2010. "Interim limited leases" authorize data gathering activities, allowing for the construction of meteorological towers on the Outer Continental Shelf to collect site-specific data on wind speed, intensity, and direction.
} 
Of the projects identified in Figure 6, three have signed or proposed power purchase agreements with terms and details that have been made public (see Table 4). As shown, offshore wind energy prices are substantially greater than those presented later for land-based wind energy.

Table 4. Proposed Power Purchase Agreements for Offshore Wind Power Projects

\begin{tabular}{|c|c|c|c|}
\hline Seller & Purchaser & Location / Amount & Contract Details \\
\hline NRG Bluewater & Delmarva & $\begin{array}{l}\text { Delaware } \\
200 \mathrm{MW}^{*}\end{array}$ & $\begin{array}{l}25 \text {-yr contract for electricity and a portion } \\
(28.6 \%) \text { of the RECs: } \$ 132 / \mathrm{MWh} \text { in } 2013 \text {, } \\
\text { escalating at } 2.5 \% / \mathrm{yr} \text {; approved by } \\
\text { regulatory commission in July } 2008\end{array}$ \\
\hline $\begin{array}{l}\text { Deepwater } \\
\text { Wind }\end{array}$ & National Grid & $\begin{array}{l}\text { Rhode Island } \\
28.8 \mathrm{MW}\end{array}$ & $\begin{array}{l}\text { 20-yr contract for electricity and RECs: } \\
\$ 244 / \mathrm{MWh} \text { in } 2013 \text {, escalating at 3.5\%/yr; } \\
\text { filed with regulatory commission in June } \\
2010\end{array}$ \\
\hline Cape Wind & National Grid & $\begin{array}{c}\text { Massachusetts } \\
50 \% \text { of } 468 \mathrm{MW}^{* *}\end{array}$ & $\begin{array}{l}\text { 15-yr contract for electricity and RECs: } \\
\$ 187 / \mathrm{MWh} \text { in } 2013 \text {, escalating at } 3.5 \% / \mathrm{yr} \text {; } \\
\text { filed with regulatory commission in May } \\
2010 \text { with revisions in July } 2010\end{array}$ \\
\hline
\end{tabular}

Source: Berkeley Lab review of regulatory filings

* NRG Bluewater has contracted for an additional $93 \mathrm{MW}$ from their $450 \mathrm{MW}$ proposed Delaware facility under a memorandum of understanding with the Delaware Electric Municipal Corporation and a contract with the University of Maryland.

** National Grid is also seeking approval of a second nearly-identical but conditional PPA for the remaining $50 \%$ that is intended to be available for assignment to other parties in the future and is intended to facilitate project financing.

Several other project-level announcements in 2009 and early 2010 demonstrate the accelerating pace of offshore wind power development in the United States. Most notably, after nine years in the permitting process, the $468 \mathrm{MW}$ Cape Wind project was granted approval by MMS in April 2010, following the 2009 completion of MMS's Final Environmental Impact Statement as well as the state and local permitting process. Cape Wind also selected a turbine supplier in 2010 (Siemens 3.6 MW turbines), received FAA approval, and filed a PPA for consideration before the state's utility regulatory commission. ${ }^{14}$

In Delaware, NRG Bluewater Wind was awarded an interim limited lease by MMS in 2009, and a contract with the University of Maryland was announced for an additional $55 \mathrm{MW}$ of the project's output (i.e., in addition to the $200 \mathrm{MW}$ contract with Delmarva shown in Table 4). In New Jersey, NRG Bluewater Wind, Garden State Offshore Energy, and Fisherman's Energy were all awarded interim limited leases by MMS in 2009, and each is benefiting from a state funding cost share for meteorological testing. Garden State Offshore Energy, a joint venture between Public Service Enterprise Group and Deepwater Wind, was selected by the New Jersey Board of Public Utilities in 2008 to receive a $\$ 4$ million grant from the state in support of a 350 MW offshore project, with additional agreements with NRG Bluewater Wind and Fisherman's Energy following. In Rhode Island, the PPA for the 28.8 MW Block Island demonstration project was initially rejected by the state's public utilities commission in March 2010, but subsequent state legislation has led to contract modifications and re-submittal to the commission in June 2010 for further consideration; in early 2009, Rhode Island signed a joint development

\footnotetext{
${ }^{14}$ Also in Massachusetts, the Town of Hull is considering shelving a small, planned offshore project due to cost concerns.
} 
agreement with Deepwater Wind under which Deepwater was selected as the state's preferred offshore wind power project developer for both the demonstration project and a subsequent, larger project. In Ohio, the final feasibility study for a $20 \mathrm{MW}$ offshore wind power project was completed in 2009, and an agreement was signed in 2010 for the purchase of five 4 MW GE turbines; GE's purchase in 2009 of offshore turbine manufacturer ScanWind presumably helped enable the agreement. In December 2009, the New York Power Authority issued a request for proposals to select developers for projects of at least $120 \mathrm{MW}$ (and up to $500 \mathrm{MW}$ ) in Lake Erie and/or Lake Ontario; five responses were received, and selections are expected in late 2010 or early 2011. The Long Island Power Authority, Consolidated Edison, and the New York Power Authority are also collaborating on a possible offshore wind power project off the coast on Long Island, with an application for a federal lease currently anticipated in 2010. In North Carolina, Duke Energy signed a contract in October 2009 with UNC Chapel Hill to install three demonstration turbines in Pamlico Sound; Duke Energy will pay for the turbines and their installation. Finally, Texas has state authority over permitting to 10 miles offshore, and a number of leases have been issued to projects in various stages of development.

In addition to these project-level developments, policy and regulatory activity related to offshore wind energy deployment continued. Following the early 2009 announcement of MMS's rules governing offshore wind power development leases, easements, and royalties, the federal government has moved towards implementation. The creation of a new regional MMS office to coordinate and appropriately expedite renewable energy development on the Atlantic Outer Continental Shelf was announced in 2010, for example, as was the creation of the Atlantic Offshore Wind Energy Consortium, through which the Department of the Interior and East Coast states will facilitate federal-state cooperation on offshore wind power development on the Outer Continental Shelf. Earlier in 2009, MMS and FERC came to agreement on their respective roles in offshore energy development. MMS subsequently began to issue limited leases for five years of resource testing under an interim policy. Then, in April 2010, MMS released a Request for Information (RFI) for commercial leasing for wind power on the outer continental shelf off of Delaware. The RFI invites interested parties to submit descriptions of their interest in obtaining a commercial lease in specific areas off the coast of Delaware. The RFI details information that developers should submit and all parties are invited to submit information on environmental issues of concern. MMS (now called the Bureau of Ocean Energy) is required to issue leases competitively, and the RFI is the first step in determining if there is competitive interest in wind energy off the Delaware coast.

At the state level, the final Massachusetts Ocean Management Plan was released in December 2009, which (among other provisions) encourages community-scale offshore wind power development, creates a formal role for regional planning authorities in offshore energy planning, and identifies two larger designated offshore wind energy areas in state waters. In Maine, legislation was passed in 2010 establishing a goal for at least $300 \mathrm{MW}$ of offshore wind energy by 2020 and 5,000 MW by 2030, and implementing other regulatory changes intended to facilitate offshore wind power development in the state; Maine also received Recovery Act funds from DOE to support offshore wind energy research, testing, and demonstration projects. Finally, in late 2009, three Mid-Atlantic states (Maryland, Delaware, and Virginia) signed an agreement to work together collaboratively on regional offshore wind power development. 


\section{Data from Interconnection Queues Demonstrate that an Enormous Amount of Wind Power Capacity Is Under Consideration}

One visible testament to the increased interest in wind energy is the amount of wind power capacity currently working its way through the major transmission interconnection queues across the country. Figure 7 provides this information for wind power and other resources aggregated across 33 different interconnection queues administered by independent system operators (ISOs), regional transmission organizations (RTOs), and utilities. ${ }^{15}$ These data should be interpreted with caution: though placing a project in the interconnection queue is a necessary step in project development, being in the queue does not guarantee that a project will actually get built. In fact, there is a growing recognition that many of the projects currently in interconnection queues are very early in the development process. As a result, efforts have been and are being taken by the Federal Energy Regulatory Commission (FERC), ISOs, RTOs, and utilities to reduce the number of speculative projects that have - in recent years - clogged these queues (Porter et al. 2009).

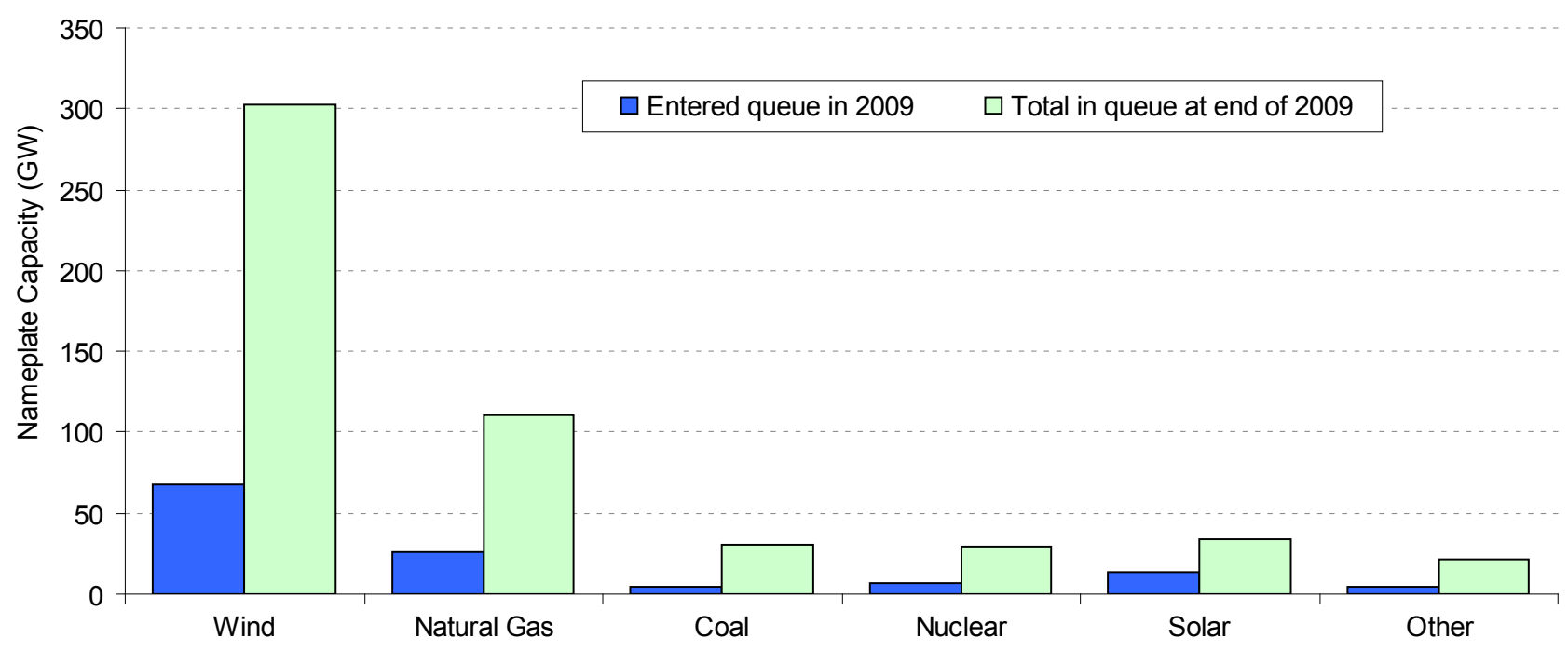

Source: Exeter Associates review of interconnection queues

Figure 7. Nameplate Resource Capacity in 33 Selected Interconnection Queues

Even with this important caveat, the amount of capacity in the nation's interconnection queues still provides at least some indication of the amount of wind power development that is in the planning phase. At the end of 2009, even after reforms by a number of ISOs, RTOs, and utilities to reduce the number of projects in their queues, there were roughly $300 \mathrm{GW}$ of wind power capacity within the interconnection queues reviewed for this report - nearly nine times the

\footnotetext{
${ }^{15}$ The queues surveyed include PJM Interconnection, Midwest Independent System Operator (MISO), New York ISO, ISO-New England, California ISO, Electricity Reliability Council of Texas (ERCOT), Southwest Power Pool (SPP), Western Area Power Administration (WAPA), Bonneville Power Administration (BPA), Tennessee Valley Authority (TVA), and 23 other individual utilities. To provide a sense of sample size and coverage, the ISOs, RTOs, and utilities whose queues are included here have an aggregated peak demand of almost $70 \%$ of the U.S. total. Figures 7 and 8 only include projects that were active in the queue at the end of 2009 but that had not yet been built; suspended projects are not included.
} 
installed wind power capacity in the United States. ${ }^{16}$ This wind power capacity represented almost $60 \%$ of all generating capacity within these selected queues at that time, and was nearly three times as much capacity as the next-largest resource in these queues, natural gas.

Much of this wind power capacity is planned for the Midwest, Mountain, Texas, PJM, SPP, and Northwest regions: wind power projects in the interconnection queues in these regions account for $93 \%$ of the aggregate $303 \mathrm{GW}$ of wind power in the selected queues (see Figure 8). At the other end of the spectrum, smaller amounts of wind power capacity are represented in the interconnection queues of the California ISO (3.4\%), New York ISO (2.3\%), ISO-New England $(1.2 \%)$, and the Southeast $(0.1 \%)$.

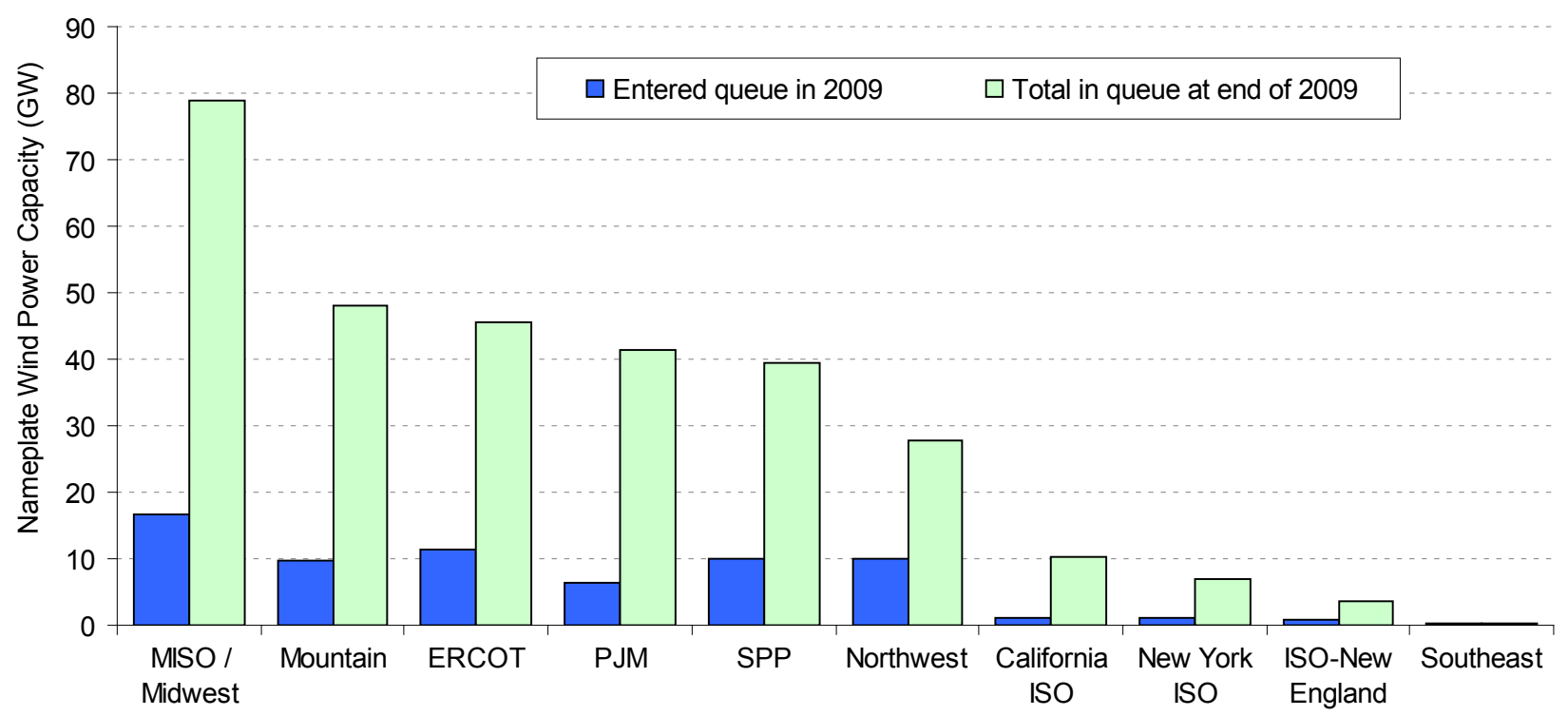

Source: Exeter Associates review of interconnection queues

Figure 8. Wind Power Capacity in 33 Selected Interconnection Queues

As another data point, the North American Electric Reliability Corporation (NERC) finds that roughly $210 \mathrm{GW}$ of new wind power capacity is planned for construction over the next ten years in the United States (NERC 2009a). Once again, though, it is unlikely that all of these planned projects will ultimately come to fruition within this time frame. As a measure of the near-term development pipeline, Ventyx (2010) estimates that - as of late-July 2010 - more than $31 \mathrm{GW}$ of wind power capacity was either under construction or in site preparation (5 GW of the $31 \mathrm{GW}$ total), in-development and permitted $(12 \mathrm{GW}$ of the $31 \mathrm{GW})$, or in-development with pending permit and/or regulatory applications (the remaining $14 \mathrm{GW}$ of the $31 \mathrm{GW}$ total). AWEA (2010c), meanwhile, identified 5,700 MW of wind power projects that were under construction as of mid-2010.

\footnotetext{
${ }^{16}$ As a rough benchmark, $300 \mathrm{GW}$ of wind power capacity is also the approximate amount of capacity required to reach $20 \%$ wind energy penetration in the United States, as estimated in DOE (2008).
} 


\section{Industry Trends}

\section{GE Remained the Top Turbine Manufacturer in the U.S. Market, but a Growing Number of Other Manufacturers Are Capturing Market Share}

General Electric (GE) remained the number one manufacturer of wind turbines supplying the U.S. market in 2009 , with $40 \%$ of domestic turbine installations (down slightly from $43 \%$ in 2008, 45\% in 2007, and 47\% in 2006). ${ }^{17}$ Following GE were Vestas (15\%), Siemens (12\%), Mitsubishi (8\%), Suzlon (7\%), Clipper (6\%), Gamesa (6\%), REpower (3\%), Acciona (2\%), and Nordex (1\%). Other utility-scale $(>100 \mathrm{~kW})$ wind turbines installed in the United States in 2009 (and that fall into the "Other" category in Figure 9) include turbines from NedWind (6.5 MW), AAER (6 MW), DeWind (6 MW), Fuhrlander (4.5 MW), Goldwind (4.5 MW), RRB (2.4 MW), Elecon (0.6 MW), and Wind Energy Solutions (0.25 MW).

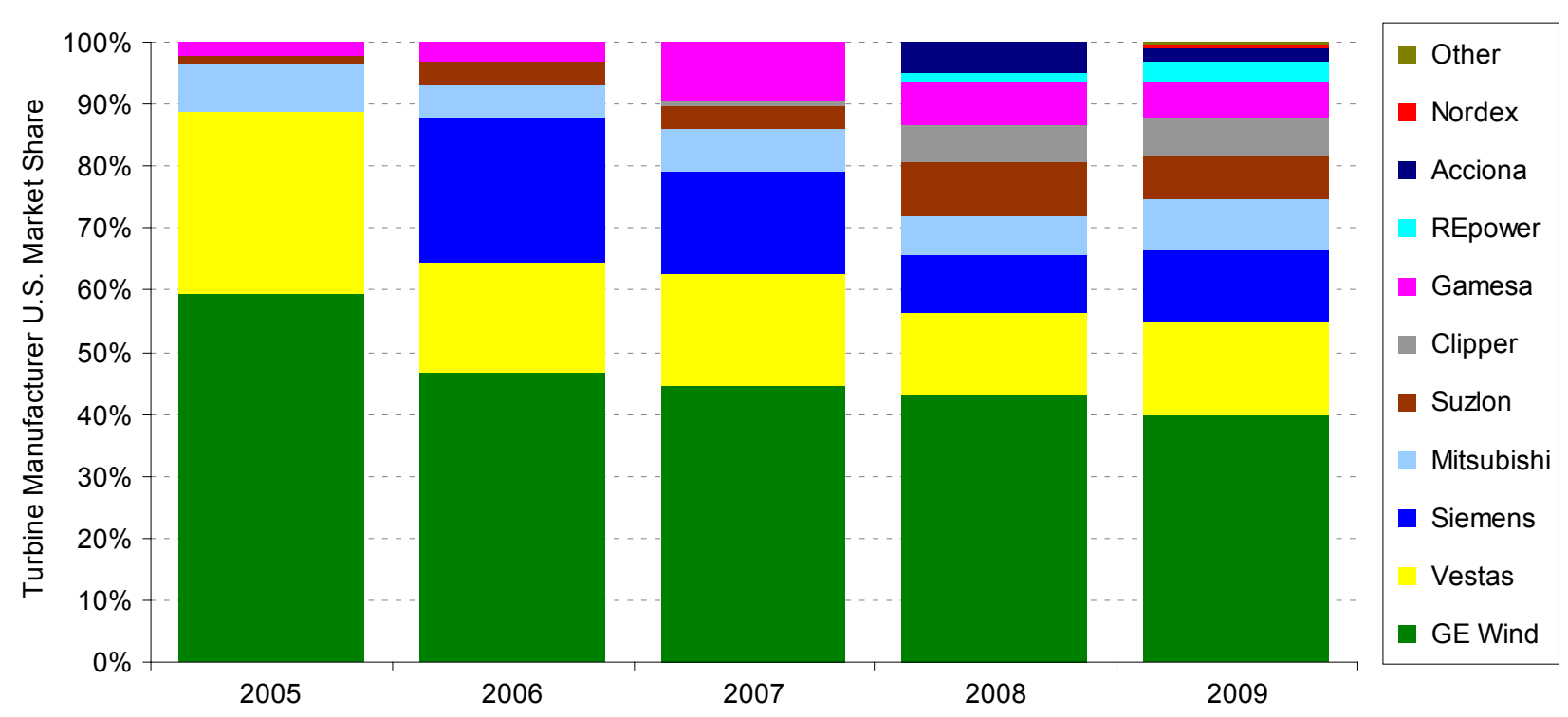

Source: AWEA project database

Figure 9. Annual U.S. Market Share of Wind Manufacturers by MW, 2005-2009

A notable increase in competition among wind turbine manufacturers has occurred since 2005, with the number of manufacturers installing more than $1 \mathrm{MW}$ increasing from just 6 in 2005 to 16 manufacturers in 2009. Consequently, the market share of the leading manufacturers - in percentage terms - has generally declined. Manufacturers with modern wind turbines installed in the United States now hail from not just the United States, Europe, and Japan, but also from India and, for the first time in 2009, China. Chinese and South Korean manufacturers, in particular, began to express strong interest in entering the U.S. market in 2009, though the timing and speed of that entry remains uncertain.

\footnotetext{
${ }^{17}$ Market share reported here is in MW terms, and is based on project installations in the year in question, not turbine shipments or orders.
} 
Notwithstanding any changes in market share that have occurred in percentage terms, most manufacturers saw installations of their turbines grow between 2008 and 2009, in many cases significantly. As shown in Table 5, the most significant growth was experienced by GE $(+410$ MW), Vestas and Siemens (+370 MW each), Mitsubishi (+298 MW), and REpower (+236 MW). Suzlon and Gamesa each installed a few less MW in the United States in 2009 than in 2008, while Acciona's installations declined by a more significant amount (-206 MW).

Table 5. Annual U.S. Turbine Installation Capacity, by Manufacturer

\begin{tabular}{|c|c|c|c|c|c|}
\hline \multirow{2}{*}{ Manufacturer } & \multicolumn{5}{|c|}{ Turbine Installations (MW) } \\
\hline & 2005 & 2006 & 2007 & 2008 & 2009 \\
\hline GE Wind & 1,433 & 1,146 & 2,342 & 3,585 & 3,995 \\
\hline Vestas & 700 & 439 & 948 & 1,120 & 1,490 \\
\hline Siemens & 0 & 573 & 863 & 791 & 1,162 \\
\hline Mitsubishi & 190 & 128 & 356 & 516 & 814 \\
\hline Suzlon & 25 & 92 & 197 & 736 & 702 \\
\hline Clipper & 3 & 0 & 48 & 470 & 605 \\
\hline Gamesa & 50 & 74 & 494 & 616 & 600 \\
\hline REPower & 0 & 0 & 0 & 94 & 330 \\
\hline Acciona & 0 & 0 & 0 & 410 & 204 \\
\hline Nordex & 0 & 0 & 3 & 0 & 63 \\
\hline Other & 2 & 2 & 0 & 12 & 31 \\
\hline TOTAL & 2,402 & 2,454 & 5,249 & 8,350 & 9,994 \\
\hline
\end{tabular}

Source: AWEA project database

In 2009, U.S.-owned GE was the second-leading supplier of turbines globally, with a $12.4 \%$ market share, slightly behind Vestas' $12.5 \%$ market share. Clipper was the $13^{\text {th }}$ largest manufacturer, with $1.6 \%$ of the worldwide market (BTM 2010). ${ }^{18}$ On a worldwide basis, perhaps the most significant story of 2009 was the growing market share of Chinese turbine manufactures; to date, that growth has been based almost entirely on sales to the Chinese market.

\section{Domestic Wind Turbine and Component Manufacturing Investments Remained Strong in 2009, but the Financial Crisis and Weak Turbine Sales Slowed the Sector's Growth}

As wind power deployment has increased in the United States, a growing number of foreign and domestic turbine and component manufacturers have begun or continued to localize and expand operations across the nation.

Though the financial crisis resulted in a slowdown in overall U.S. manufacturing in 2009, wind equipment manufacturing was, to a degree, a bright spot. Figure 10 presents a non-exhaustive list of 13 wind turbine and component manufacturing and assembly facilities that opened in 2009, and identifies their location. The map also depicts the location of 21 new manufacturing

\footnotetext{
${ }^{18}$ In addition, U.S. manufacturers are major players in the global market for smaller-scale turbines (AWEA 2010b).
} 
facilities announced (but not yet built) in 2009, identifies 12 existing firms that expanded into the wind energy sector in 2009, and plots 125 existing turbine and component manufacturing facilities that opened prior to 2009.

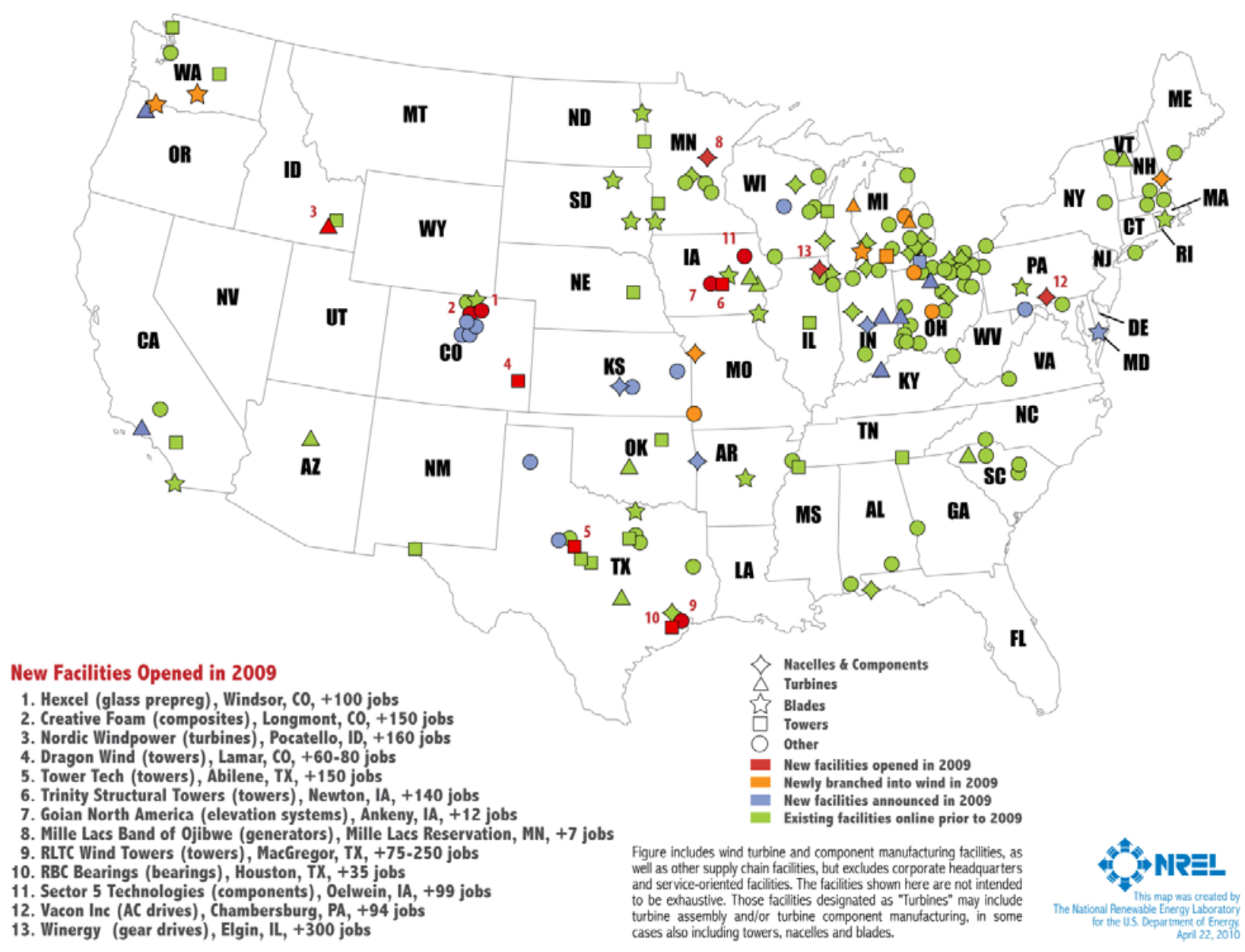

Figure 10. Location of Existing and New Turbine and Component Manufacturing Facilities

Of the 34 new or announced facilities in 2009 captured in Figure 10, two are owned by major international wind turbine original equipment manufacturers (OEMs): Siemens (nacelles in Hutchinson, Kansas), and Mitsubishi Power Systems (nacelles in Fort Smith, Arkansas). In addition, GE announced plans to open a research facility in Van Buren Township, Michigan. (Research facilities are not included in the figure).

Several smaller- to mid-sized OEMs also opened or announced U.S. factories in 2009. Nordic Windpower, for example, opened a turbine manufacturing and assembly facility in Pocatello, Idaho, where it is producing and assembling its $1 \mathrm{MW}$ turbines. Continental Wind announced that it would open a turbine manufacturing facility in Santa Paula, California, where it will reportedly focus on the production of turbines ranging from $300-900 \mathrm{~kW}$. Still other firms, including a number of major international turbine vendors, continued to make progress in 
establishing themselves in the U.S. market based on manufacturing plans announced prior to 2009.

As a result of this activity, seven of the ten OEMs with the largest share of the U.S. market in 2009 (GE, Vestas, Siemens, Suzlon, Clipper, Gamesa, Acciona) have one or more manufacturing facilities operating in the United States, and two of the remaining three (Mitsubishi, Nordex) have announced specific plans to open facilities in the future. These figures compare to just one utility-scale wind turbine OEM assembling nacelles in the United States in 2004 (GE). Still other active domestic and foreign OEMs have already established manufacturing facilities in the United States (Nordic, DeWind) or have at least tentatively announced the location of future U.S. manufacturing facilities (Alstom, Emergya, Fuhrlander, A-Power, Ming Yang), ${ }^{19}$ while several U.S. companies have announced their interest in manufacturing but have not yet built any utilityscale turbines (e.g., Northern Power Systems, Continental Wind).

Other notable developments from 2009 and early 2010 include the cash infusions garnered by emerging domestic turbine OEMs, and the increased interest in the United States market by Asian players. Clipper, for example, received a cash infusion through the sale of $49.5 \%$ of the company to United Technologies Corporation, while Nordic Windpower also raised substantial new capital. Meanwhile, in addition to Mitsubishi's planned nacelle assembly facility, new Asian OEMs from South Korea and China demonstrated interest in the U.S. market. South Korea's Samsung, Hyundai, and Unison, for example, all announced interest in U.S. sales of wind turbines, while California-based Composite Technology Corporation sold its DeWind manufacturing business to South Korea's Daewoo Shipbuilding \& Marine Engineering. China's Goldwind installed its first wind turbines on United States soil in 2009, and a number of other Chinese manufacturers have also announced their entry into the market; in early 2010, for example, A-Power and Ming Yang announced the location of possible future manufacturing facilities in Nevada and Texas, respectively.

Figure 10 shows a considerable number of new component manufacturing facilities announced or opened in 2009, from both foreign and domestic firms. A number of domestic manufacturers that were not previously active in the wind energy sector transitioned into the industry in 2009: five such companies are located in Michigan, one of the states hardest hit by the economic downturn. These facilities span the entire supply chain. Though new and announced component manufacturing facilities are spread across the country, a number of companies are choosing to locate near already-established large-scale OEMs; for example, in 2009, six component suppliers announced or opened facilities in Colorado, where Vestas has made significant investments.

Some of the states that have experienced the greatest growth in installed wind power capacity in recent years are also seeing significant new manufacturing activity. Even states with little installed wind power capacity, however, are reaping job and economic benefits from new windrelated manufacturing facilities, particularly if those states are strategically positioned geographically near the main wind power markets and in locations that minimize transportation logistics challenges and costs (e.g., Arkansas).

\footnotetext{
${ }^{19}$ Some of these announcements preceded 2009, or were in early 2010, and so are not included in Figure 10.
} 
As a result of these developments, AWEA (2010a) estimates that the wind energy sector employed 85,000 full-time workers in the United States at the end of 2009, the same figure as in 2008 but much higher than in years prior to 2008. In addition to manufacturing, these jobs span project development, construction and turbine installation, operations and maintenance, transportation and logistics, and financial, legal, and consulting services.

Notwithstanding the generally positive outlook for the turbine manufacturing sector in the United States, however, the industry is facing economic headwinds. AWEA (2010a) estimates that 1,500 manufacturing jobs were lost in 2009 (reducing the number of wind turbine and component manufacturing jobs in the United States to around 18,500 at year end, but still up significantly from years past) as a number of firms delayed or scaled-back their expansion plans and announced layoffs as a result of weak demand for wind turbines and the poor state of the U.S. economy. With financial conditions showing signs of stabilizing, some manufacturers have already begun the process of rehiring workers and resuming their expansion plans, but the outlook for 2010 remains uncertain. In addition, as the domestic industry expands, a new challenge has become more acute: workforce training and development for all segments of the wind power industry. A variety of programs at the local and national levels are beginning to target these needs.

\section{A Growing Percentage of the Equipment Used in U.S. Wind Power Projects Has Been Sourced Domestically in Recent Years}

As a result of the foregoing developments in U.S.-based wind turbine and component manufacturing, AWEA estimates that the share of domestically manufactured wind turbines and components grew from 20-25\% in 2005 to roughly 50\% in 2009 (AWEA 2010a). David (2010) uses somewhat different methods and assumptions, and estimates that the import share of wind turbines and selected components as a proportion of total turbine costs declined from $64 \%$ in 2006 to $32 \%$ in 2009 (these data suggest a domestic content of $36 \%$ in 2006 , increasing to $68 \%$ in 2009; one reason for the difference with AWEA is that David (2010) focuses on imports as a fraction of total turbine costs - including soft costs associated with turbine sales transactions whereas AWEA (2010a) focuses on imports as a fraction of turbine equipment costs alone). ${ }^{20}$

These general trends are confirmed in this section by relying upon similar import data as used by David (2010), specifically data from the U.S. Department of Commerce, ${ }^{21}$ but with somewhat different assumptions and data processing. This analysis supports the basic conclusion that the United States remains a large importer of wind power equipment, but that wind power capacity

\footnotetext{
${ }^{20}$ Despite the different approaches taken, AWEA (2010a), David (2010), and the analysis presented in this section all focus on wind turbines and components and wind turbine costs. Excluded from all three analyses are foundations, electrical collection and grid interconnection systems, roads, project development costs, and other nonturbine balance-of-plant expenditures. Following the approach used by AWEA (2010a), and unlike David (2010), our analysis emphasizes equipment imports as a fraction of wind turbine equipment-related costs alone.

${ }^{21}$ The Department of Commerce trade data are accessed through the U.S. International Trade Commission's (USITC) DataWeb, which compiles statistics from the Department of Commerce on imports and exports. The statistics can be queried online at: http://dataweb.usitc.gov/. The analysis presented here relies on the 'customs value' of imports as opposed to the 'landed value.' For more information on these data and their application to wind energy, see David (2009, 2010).
} 
growth is outpacing growth in imports, yielding a growing share of domestic manufacturing content.

Figure 11 presents calendar-year data on U.S. imports and exports of wind-powered generating sets from 2006 through 2009. ${ }^{22}$ Wind-powered generating sets include nacelles and, when imported with the nacelle, certain turbine components. (Data on the separate importation of turbine components are additive to the data shown in Figure 11, are reported in Figure 12, and are discussed later in this section).

As shown in Figure 11, U.S. imports of wind-powered generating sets grew from $\$ 1.3$ billion in 2006 to nearly $\$ 2.5$ billion in both 2007 and 2008, before falling to roughly \$2.3 billion in 2009 (all data are presented in real 2009 dollars). At $\$ 2.3$ billion, the United States was - by far - the largest importer of wind-powered generating sets in 2009, representing approximately $34 \%$ of worldwide imports (no other country reached $10 \%$ of global imports). ${ }^{23}$ The primary source markets from which these imports to the United States originate have been and continue to be the home countries of the major international wind turbine manufacturers: Denmark, Spain, Japan, India, and Germany.

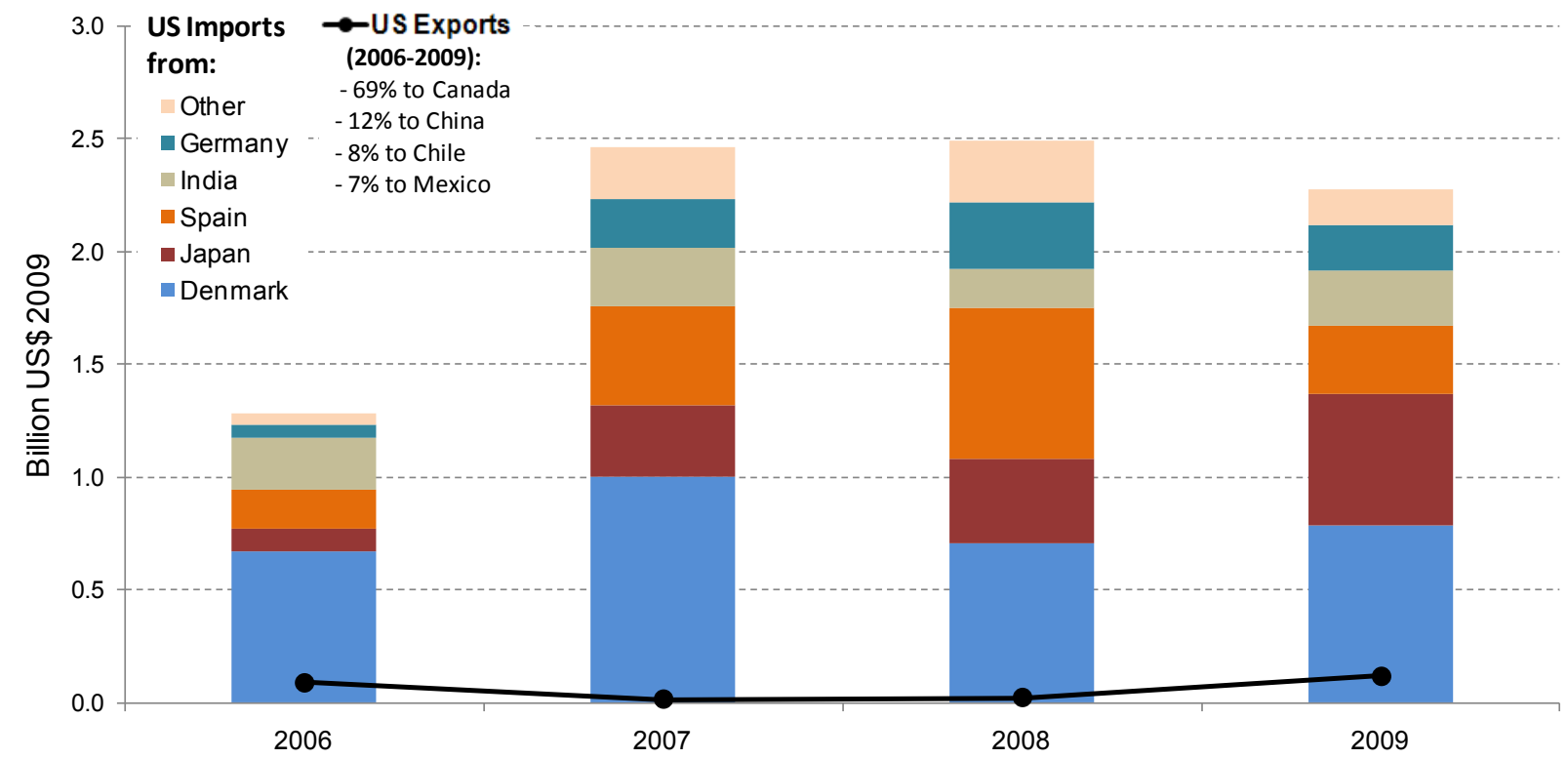

Source: Berkeley Lab analysis of data from USITC DataWeb: http://dataweb.usitc.gov

\section{Figure 11. Imports and Exports of Wind-Powered Generating Sets}

Exports of wind-powered generating sets from the United States increased to \$120 million in 2009 , up from roughly $\$ 20$ million in 2008. The largest destination markets for U.S. exports over the entire 2006-2009 timeframe included Canada (69\%), China (12\%), Chile (8\%), and

\footnotetext{
${ }^{22}$ Harmonized Tariff Schedule (HTS) 8502.31.0000 - "Wind-powered generating sets." This HTS code includes both utility-scale and small wind turbines. When components are imported separately from the nacelle, other tariff provisions apply (see footnote 24).

${ }^{23}$ Using similar HTS codes, data on global imports and exports come from the World Trade Atlas by Global Trade Information Services, Inc.
} 
Mexico (7\%). It is clear from Figure 11 that the United States remains a sizable net importer of wind-powered generating sets. In fact, while the United States ranks first globally as an importer of wind-powered generating sets, representing 34\% of global imports, it ranks seventh in the export of similar equipment, representing 3\% of global exports, behind the largest global exporters of Denmark (28\% of exports), Germany (23\%), Spain (19\%), Japan (12\%), and India $(8 \%)$.

The data presented in Figure 11 are for wind-powered generating sets. Wind turbine blades, hubs, generators, gearboxes, and other components are included in Figure 11 only if shipped with the nacelle itself. These same wind turbine components may also be imported separate from the nacelle, however, implying that the data presented in Figure 11 include only a fraction of total wind equipment imported into the United States. Data for the separate importation of some wind turbine components are also available and can be added to the imports shown in Figure 11, but data on the separate importation of turbine components are embedded within larger trade categories that include sectors other than wind energy.

Figure 12 presents estimated calendar-year data for the separate importation of selected wind turbine components that include towers (trade category is "towers and lattice masts"), generators ("AC generators from 750 to 10,000 kVA"), blades and other components ("parts of other engines and motors" and "parts of generators"), and gearboxes ("other fixed ratio speed changers" and "other multiple and variable ratio speed changers"). ${ }^{24}$ The import estimates shown in Figure 12 should be viewed with caution because the underlying data used to produce the figure are based on trade categories that are not exclusive to wind energy (e.g., they could include generators for non-wind applications). The wind turbine component-level import estimates shown in Figure 12 therefore required assumptions about the fraction of larger trade categories likely to be represented by wind turbine components. ${ }^{25}$

Figure 12 confirms that trends in the separate importation of certain wind turbine components is consistent with the import trends for wind-powered generating sets presented in Figure 11. The estimated imports of separate wind turbine components on a calendar-year basis, as presented in Figure 12, increased from $\$ 1.2$ billion in 2006 to $\$ 2.9$ billion in 2008 , before falling to roughly \$2 billion in 2009 (again, all dollar values are expressed in real 2009 dollars). Wind turbine component exports in these trade categories are not shown in the figure because such exports are likely a small (and uncertain) fraction of the broader trade category totals.

\footnotetext{
${ }^{24}$ Estimating separate wind turbine component imports is complicated by the fact that the HTS does not contain codes that are exclusive to wind turbine components. Included in the analysis presented here are: HTS 8501.64.0020 - "AC generators from 750 to 10,000 kVA"; HTS 8412.90.9080 - "parts of engines and motors"; HTS 8503.00.9545 - "parts of generators (other than commutators, stators, and rotors)"; HTS 7308.20.0000 "towers and lattice masts"; HTS 8483.40.5010 - "fixed ratio speed changers"; and HTS 8543.40.5050 - "speed changers other than fixed ratio."

${ }^{25}$ Specifically, based on a review of the countries of origin for the imports, personal communications with USITC and AWEA staff, David (2010), and Wyden (2010), we assume that 70\% of the 750-10,000 kVA AC generators (HTS 8501.64.0020), 25\% of the fixed and multiple/variable ratio speed changers (HTS 8483.40.5010 and HTS 8483.40 .5050 ), $70 \%$ of the parts of engines, motors, and generators (HTS 8503.00.9545 and HTS 8412.90.9080), and $95 \%$ of the towers and lattice masts (HTS 7308.20.0000) are wind-related components. We assume that these percentages apply equally across the entire 2006-2009 time period.
} 


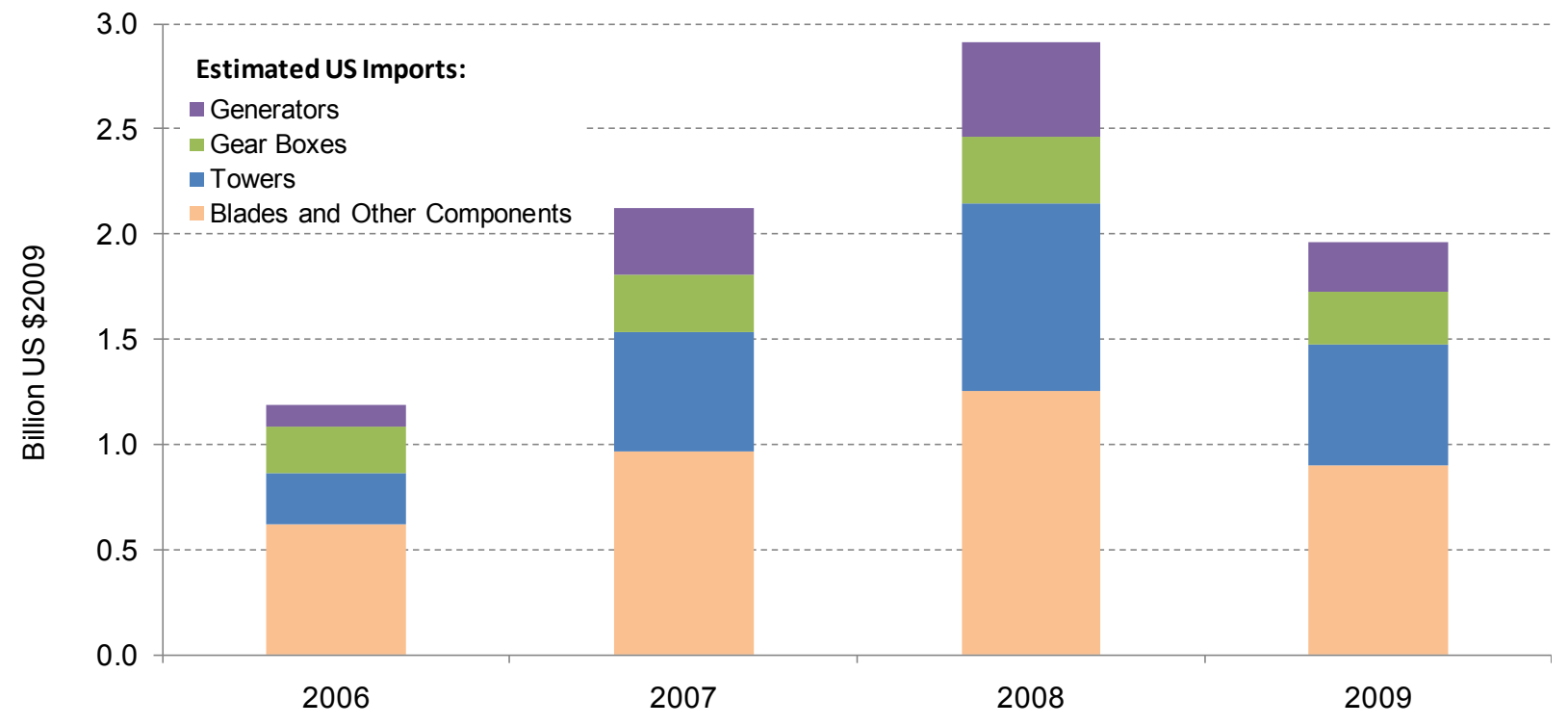

Source: Berkeley Lab analysis of data from USITC DataWeb: http://dataweb.usitc.gov

Figure 12. Estimated Imports of Goods in Trade Categories That Include Wind Turbine
Components Using Wind-Related Import Percentage Assumptions

Looking behind the data presented in Figure 12 in more regional detail, notable trends include an increase in imports of blades and other components ("parts of other engines and motors" and "parts of generators") from Mexico and India in 2009, and a sizable shift of tower and lattice mast imports away from Europe and Canada and toward Asia. Similarly, from 2006-2009, an increasing share of generator imports have come from Asia, whereas European imports have declined. $^{26}$

Though Figures 11 and 12 depict a U.S. market that remains reliant on imports of wind power equipment, that reliance has declined over time as growth in installed wind power capacity has outpaced growth in wind turbine and component imports. Specifically, adding the data in Figure 11 and Figure 12 yields an estimate of total calendar-year wind turbine equipment imports including wind-powered generating sets as shown in Figure 11 and selected turbine components as shown in Figure 12 - into the United States of $\$ 2.5$ billion in 2006, \$4.6 billion in 2007, \$5.4 billion in 2008 , and $\$ 4.2$ billion in 2009 . In aggregate, imports have substantially increased over time, peaking in 2008 and then declining in 2009. Annual wind power capacity additions have,

\footnotetext{
${ }^{26}$ Over the entire 2006-2009 timeframe, the largest source countries for the trade category that includes towers were: Korea (20\%), China (18\%), Vietnam (12\%), Denmark (11\%), and Canada (10\%) (in 2009, the top three countries were China (28\%), Korea (26\%), and Vietnam (11\%)). For the trade category that includes blades and other components, the largest source countries from 2006-2009 were: Brazil (15\%), Germany (8\%), Denmark (7\%), Mexico (4\%), and India (4\%) (in 2009, the top three countries were Brazil (20\%), Germany (11\%), and Denmark $(8 \%))$. Finally, for the trade category that includes generators, the largest source countries from 2006-2009 were Germany (37\%), Denmark (19\%), Japan (16\%), Spain (8\%), and China (4\%) (in 2009, the top three countries were Germany (32\%), Japan (31\%), and Denmark (8\%)). Not included is a country breakdown for the trade category that includes gearboxes because only $25 \%$ of the imports in that category are assumed to represent wind power equipment. Even among the categories highlighted here, source country designations should be viewed with caution since the trade categories are not exclusive to wind energy.
} 
however, outpaced imports over this timeframe, suggesting a growing share of domestic production.

To estimate the percentage share of imports and domestic production over time, one must account for the fact that turbines and components imported at the end of one year may not be installed until the following year. As such, in Figure 13 we determine the combined imports of wind-powered generating and selected turbine components by using a 4-month lag (i.e., we use monthly import data from September of the previous year to August of the current year to estimate the value of imports used in wind turbine installations in the current year). Those import figures are then compared to total wind turbine equipment-related costs on a calendaryear basis. ${ }^{27}$ When presented as a fraction of total equipment-related turbine costs in this fashion, the overall import fraction is found to have declined significantly from more than $80 \%$ in 2006 to roughly $40 \%$ in $2009 .^{28}$

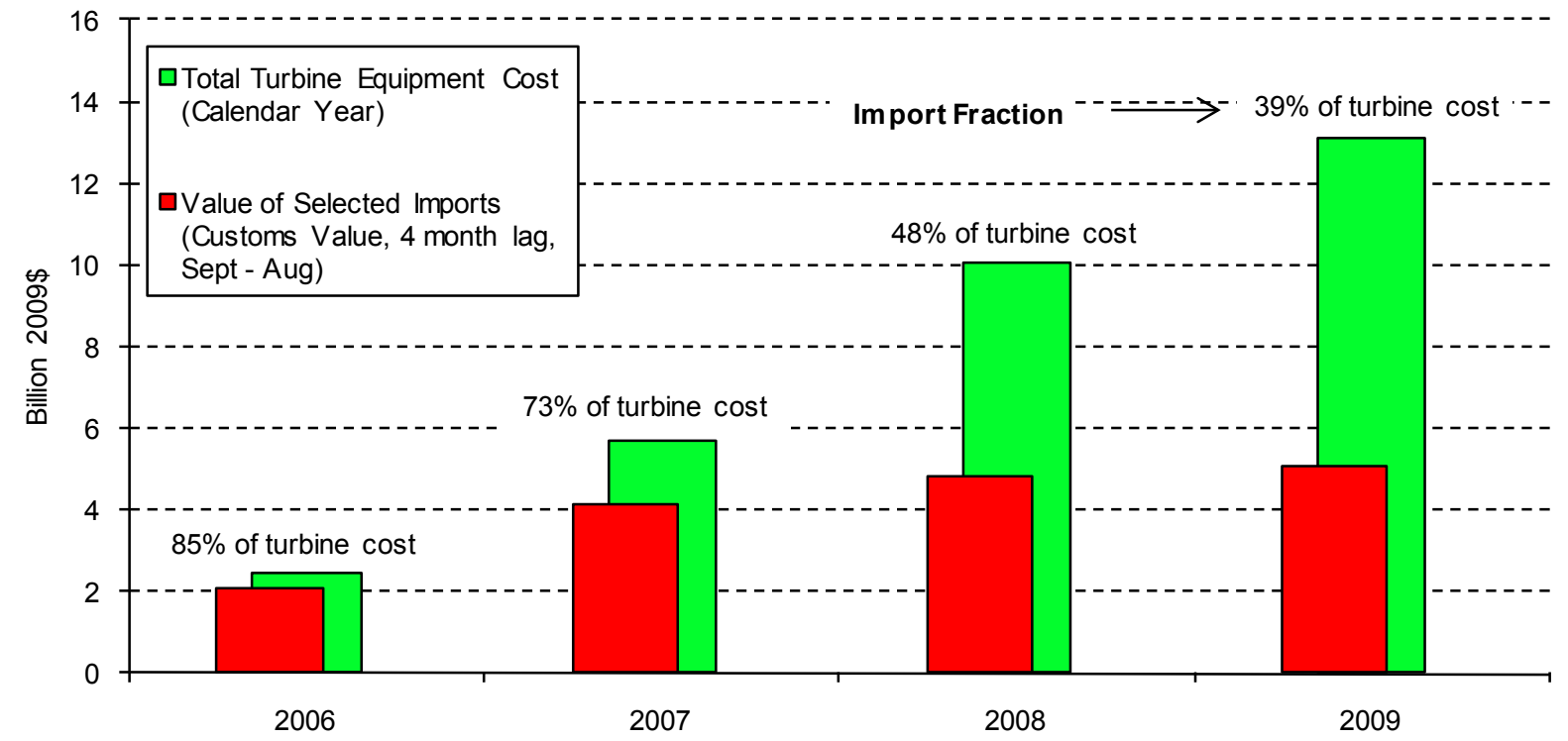

Figure 13. Wind Power Equipment Imports as a Fraction of Total Turbine Cost

These figures should be considered rough approximations for the reasons stated earlier, and may understate the wind power industry's reliance on turbine and component imports because it is possible that imports of wind power equipment are occurring under other HTS codes that are not

\footnotetext{
${ }^{27}$ Total wind turbine costs $(\$ / \mathrm{kW})$ are assumed to equal approximately $75 \%$ of the average project-level costs reported later in this report in Figure 27, while wind turbine equipment-related costs are assumed to equal $85 \%$ of total wind turbine costs (with the remaining 15\% consisting of transportation, project management, and other soft costs). To calculate total calendar-year wind turbine equipment-related costs, we multiply this wind turbine equipment-related cost figure in $\$ / \mathrm{kW}$ by annual wind power capacity installations. Note that David (2010) does not de-rate total wind turbine costs to estimate equipment-related costs alone, and the estimated import shares reported by David (2010) therefore differ somewhat from those reported here and by AWEA (2010a).

${ }^{28}$ Reporting these figures as a proportion of total wind project installed costs (not just wind turbine equipmentrelated costs) is also of interest, but is complicated by the fact that non-turbine balance-of-plant costs may also involve some level of imports. Nonetheless, if one simply assumes that $80 \%$ of non-turbine-equipment balance-ofplant costs derive from domestic sources with the remaining $20 \%$ from imports, then the import fraction for total wind project installed costs would equal $60 \%$ in 2006 , declining to $53 \%$ in $2007,37 \%$ in 2008 , and $32 \%$ in 2009 .
} 
captured here. Nonetheless, the overall findings presented here are directionally consistent with the data presented in AWEA (2010a) and David (2010): a growing amount of the equipment used in wind power projects is being sourced domestically as domestic and foreign companies seek to minimize transportation costs and currency risks through local manufacturing. Domestic manufacturing and foreign direct investment in the U.S. market are becoming increasingly prevalent relative to cross-border trade in wind power equipment (see also Kirkegaard et al. 2009). In fact, though imperfect, this analysis suggests a greater domestic share of turbine and component manufacturing than estimated by AWEA (2010a). Moreover, the planned manufacturing investments discussed in the previous section may lead to increased domestic content in the years ahead: whether that trend continues unabated, however, may depend on the size and stability of the U.S. wind power market as well as the manufacturing strategies of emerging turbine manufacturers from Asia and elsewhere.

\section{The Average Nameplate Capacity, Hub Height, and Rotor Diameter of Installed Wind Turbines Increased}

The average nameplate capacity of wind turbines installed in the United States in 2009 increased to roughly 1.74 MW (Figure 14), up from 1.66 MW in 2008 and $1.65 \mathrm{MW}$ in $2007 .{ }^{29}$ Since 1998-99, average turbine nameplate capacity has increased by $145 \%$, but growth in this metric has slowed in recent years due to the dominance of GE's 1.5 MW turbine and as a result of the logistical challenges associated with transporting larger turbines to project sites. ${ }^{30}$

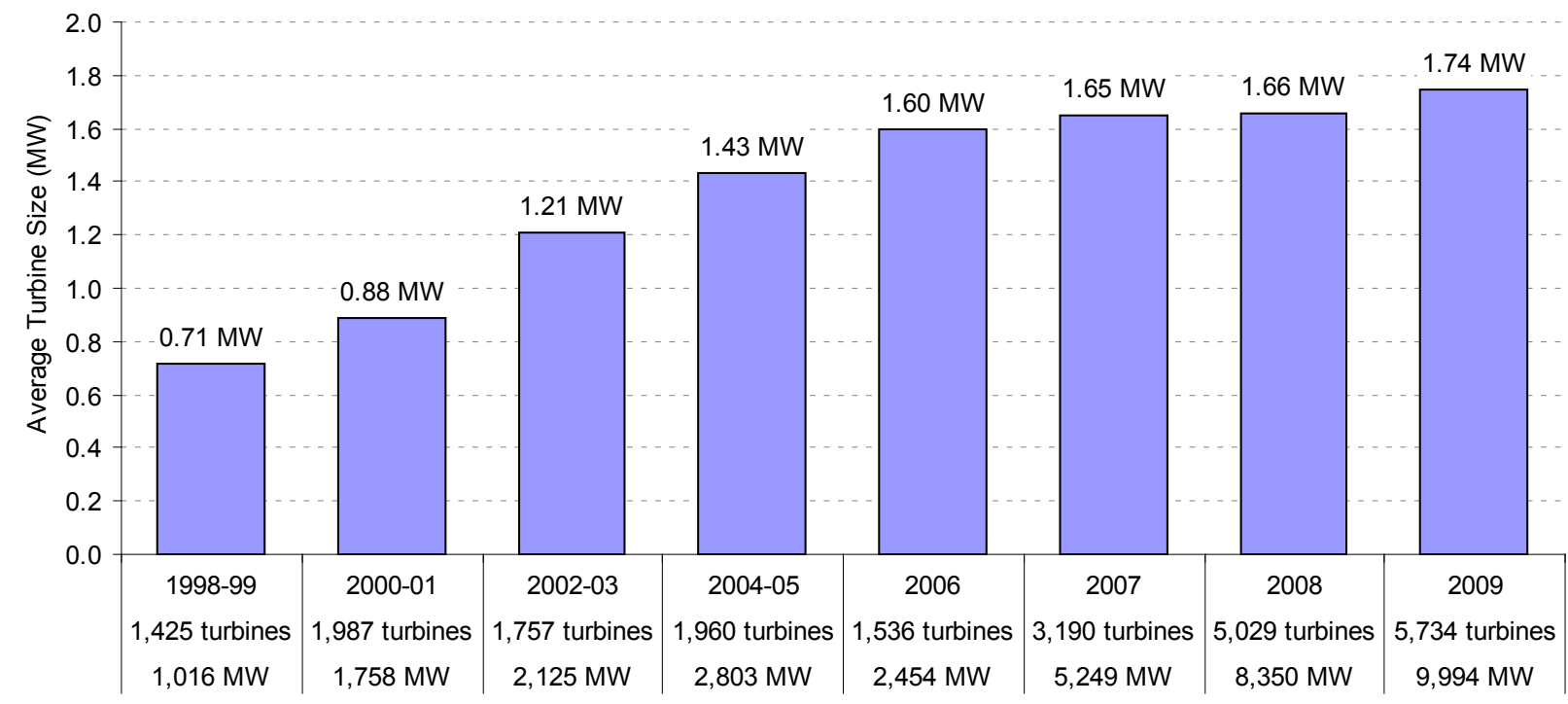

Source: AWEA project database

Figure 14. Average Turbine Nameplate Capacity Installed During Period

\footnotetext{
${ }^{29}$ Modest differences exist between these figures and those presented by AWEA (2010a) for the reasons discussed in footnote 2 .

${ }^{30}$ Figure 14 (as well as a number of the other figures and tables included in this report) combines data into both oneor two-year periods in order to avoid distortions related to small sample size in the PTC lapse years of 2000, 2002, and 2004; though not a PTC lapse year, 1998 is grouped with 1999 due to the small sample of 1998 projects.
} 
Table 6 shows how the distribution of turbine nameplate capacity has shifted over time: roughly $25 \%$ of all turbines installed in 2009 had a nameplate capacity larger than $2.0 \mathrm{MW}$, compared to $19 \%$ in $2008,16 \%$ in both 2007 and 2006 , and just $0.1 \%$ or less in years prior to 2006 . GE's 1.5 MW wind turbine remained by far the nation's most-popular turbine in 2009, with 2,663 units installed, equating to $40 \%$ of all wind power capacity installed in 2009 .

Table 6. Size Distribution of Number of Turbines Over Time

\begin{tabular}{|c|c|c|c|c|c|c|c|c|c|}
\hline & $\begin{array}{r}\text { Years: } \\
\text { \# MW: } \\
\text { turbines: }\end{array}$ & $\begin{array}{c}\mathbf{1 9 9 8 - 9 9} \\
1,016 \\
1,425\end{array}$ & $\begin{array}{c}\mathbf{2 0 0 0 - 0 1} \\
1,758 \\
1,987\end{array}$ & $\begin{array}{c}\mathbf{2 0 0 2 - 0 3} \\
2,125 \\
1,757\end{array}$ & $\begin{array}{c}\mathbf{2 0 0 4 - 0 5} \\
2,803 \\
1,960\end{array}$ & $\begin{array}{l}\mathbf{2 0 0 6} \\
2,454 \\
1,536 \\
\end{array}$ & $\begin{array}{l}\mathbf{2 0 0 7} \\
5,249 \\
3,190\end{array}$ & $\begin{array}{l}\mathbf{2 0 0 8} \\
8,350 \\
5,029\end{array}$ & $\begin{array}{l}\mathbf{2 0 0 9} \\
9,994 \\
5,734\end{array}$ \\
\hline \multirow{6}{*}{ 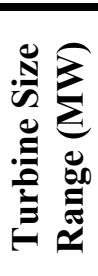 } & $0.00-0.5$ & $1.3 \%$ & $0.4 \%$ & $0.5 \%$ & $1.8 \%$ & $0.7 \%$ & $0.0 \%$ & $0.5 \%$ & $0.2 \%$ \\
\hline & 0.51-1.0 & $98.5 \%$ & $73.9 \%$ & $43.4 \%$ & $18.5 \%$ & $10.7 \%$ & $11.2 \%$ & $10.3 \%$ & $4.6 \%$ \\
\hline & $1.01-1.5$ & $0.0 \%$ & $25.4 \%$ & $43.5 \%$ & $56.0 \%$ & $54.0 \%$ & $49.2 \%$ & $53.5 \%$ & $49.4 \%$ \\
\hline & $1.51-2.0$ & $0.3 \%$ & $0.4 \%$ & $12.5 \%$ & $23.6 \%$ & $18.4 \%$ & $23.1 \%$ & $16.3 \%$ & $21.2 \%$ \\
\hline & 2.01-2.5 & $0.0 \%$ & $0.0 \%$ & $0.0 \%$ & $0.1 \%$ & $16.2 \%$ & $15.2 \%$ & $16.8 \%$ & $23.1 \%$ \\
\hline & $2.51-3.0$ & $0.0 \%$ & $0.0 \%$ & $0.1 \%$ & $0.0 \%$ & $0.0 \%$ & $1.3 \%$ & $2.5 \%$ & $1.4 \%$ \\
\hline
\end{tabular}

In addition to nameplate capacity ratings, average hub heights and rotor diameters have also scaled with time. The average hub height of wind turbines installed in the United States in 2009 was 78.8 meters (Figure 15), up slightly from 78.5 meters in 2008 and 78.2 meters in 2007. Since 1998-99, the average turbine hub height has increased by 39\% (or 22.3 meters), though year-on-year growth has slowed in the more recent years. Average rotor diameters have increased at a somewhat more rapid pace: the average rotor diameter of wind turbines installed in the United States in 2009 was 81.6 meters (Figure 15), up from 79.4 meters in 2008 and 79.2 meters in 2007. Since 1998-99, the average rotor diameter has increased by $69 \%$ (or 33.2 meters). For turbines installed in 2009, the maximum hub height and rotor diameter were 80 meters and 101 meters, respectively (a higher maximum hub height of 105 meter exists for turbines installed in 2008). These trends in hub height and rotor scaling are one of several factors impacting the project-level capacity factors highlighted later in this report. 


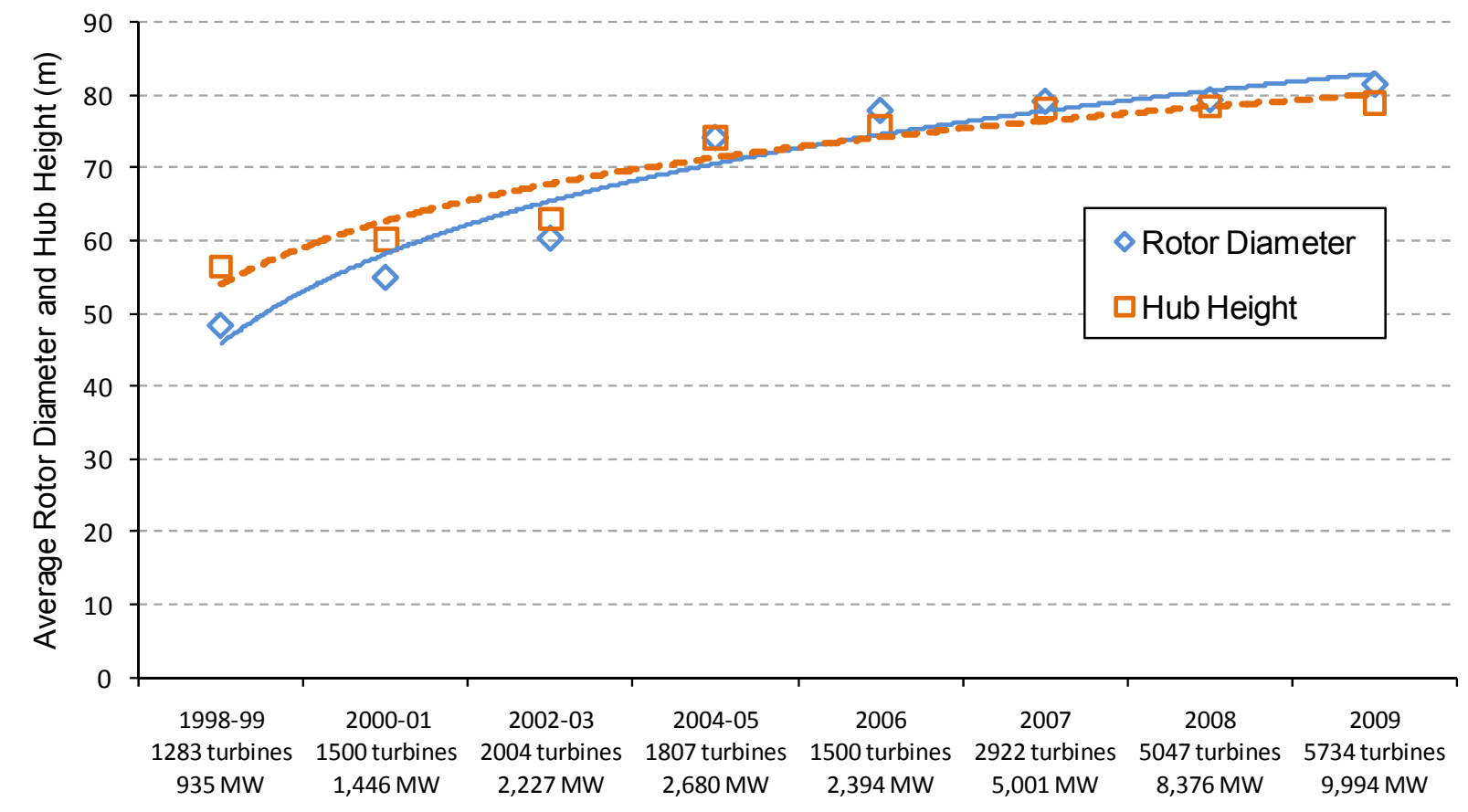

Source: Berkeley Lab

Figure 15. Average Rotor Diameter and Hub Height Installed During Period

\section{The Average Size of Wind Power Projects Resumed its Upward Trend}

As the wind power industry has grown, so too has the average size of installed wind power projects. Projects installed in 2009 averaged nearly $91 \mathrm{MW}$, which is below the $120 \mathrm{MW}$ average size of projects built in 2007, but is otherwise larger than in any other period (Figure 16).

The long-term increase in average project size may reflect a number of interrelated trends highlighted elsewhere in this report: growing demand for wind power; the upward march in turbine size; the large turbine orders that had become standard practice up until the 2008/2009 credit crisis; consolidation among project developers to support those orders; and increasing turbine and project costs, which may require taking full advantage of any and all economies of scale. Whatever the specific cause, larger project sizes reflect an increasingly mature energy source that is beginning to penetrate into the domestic electricity market in a significant way. 


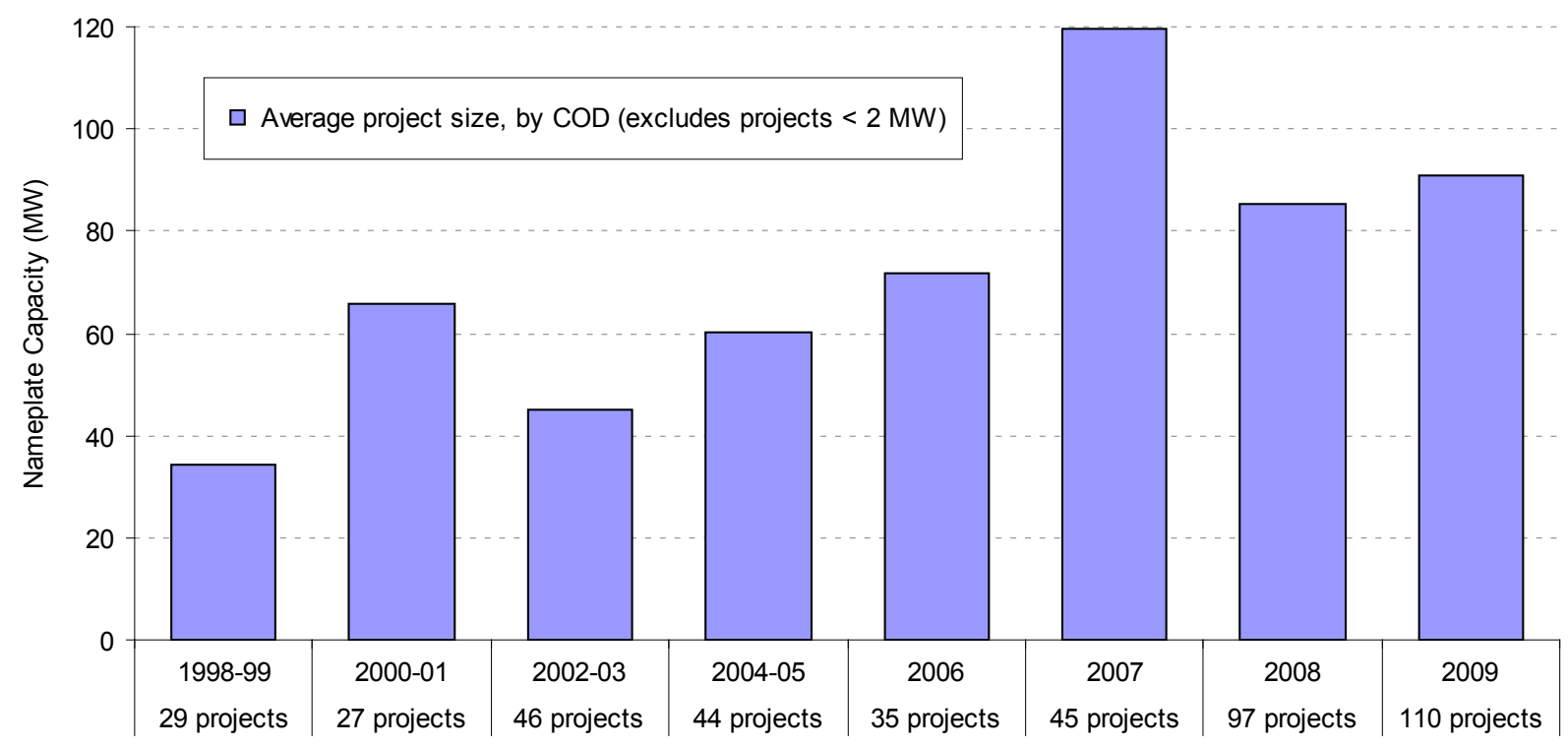

Source: Berkeley Lab analysis of AWEA project database

Figure 16. Average Project Size, by Commercial Operation Date (COD) ${ }^{31}$

\section{Consolidation Among Wind Project Developers Continues}

Consolidation on the development end of the wind power business has slowed somewhat since 2007, but in 2009 remained on par with the pace set in 2008. The more-subdued pace of activity since 2007 may be a reflection of several factors, including the simple fact that many of the prime targets for investment and/or acquisition were acquired in earlier years. In addition, some traditional buyers of U.S. wind assets may have decided to reign in new investments following aggressive purchases made in previous years, while some developers who might otherwise entertain offers may be holding out for better pricing as the market recovers. Looking ahead, however, the relatively weak demand for wind energy projected in 2010 (and the trouble that will cause for smaller developers), coupled with an influx of cash from the Section 1603 Treasury grant program, may help to drive continued consolidation.

Table 7 provides a listing of announced acquisition and investment activity among U.S. wind project developers from 2002 through 2009. ${ }^{32}$ At least six significant transactions involving roughly $18 \mathrm{GW}$ of in-development wind power projects (also called the development "pipeline") were announced in 2009 , similar to the five transactions and $19 \mathrm{GW}$ in 2008 , but well below the

\footnotetext{
${ }^{31}$ Projects less than $2 \mathrm{MW}$ in size are excluded from Figure 16 so that a large number of single-turbine "projects" (that, in practice, may have been developed as part of a larger, aggregated project) do not end up skewing the average. For projects installed in phases, each phase is considered to be a separate project. Projects that are partially constructed in two different years are counted as coming online in the year in which a clear majority of the capacity was completed. If roughly equal amounts of capacity are built in each year, then the full project is counted as coming online in the later year. Due to methodological differences, these figures differ somewhat from those presented in AWEA (2010a), though the trend is consistent.

${ }^{32}$ Only announced transactions that are believed to involve $500 \mathrm{MW}$ or more of in-development U.S. wind power projects are included. Not included are transactions in which one developer purchases another developer's project pipeline, without an actual acquisition of or investment in that developer.
} 
11 transactions and $37 \mathrm{GW}$ in 2007, and the 12 transactions and $34 \mathrm{GW}$ in 2006. In 2005, eight transactions totaling $11 \mathrm{GW}$ were announced, while only four transactions totaling less than 4 GW were completed from 2002 through 2004.

Table 7. Announced Acquisition and Investment Activity Among Wind Developers*

\begin{tabular}{|c|c|c|c|}
\hline Investor & Transaction Type & Developer & Announcement Date \\
\hline EDF (SIIF Energies) & Acquisition & enXco & May-02 \\
\hline Gamesa & Investment & Navitas & Oct-02 \\
\hline AES & Investment & U.S. Wind Force & Sep-04 \\
\hline PPM (Scottish Power) & Acquisition & Atlantic Renewable Energy Corp. & Dec-04 \\
\hline AES & Acquisition & SeaWest & Jan-05 \\
\hline Goldman Sachs & Acquisition & Zilkha (Horizon) & Mar-05 \\
\hline JP Morgan Partners & Investment & Noble Power & Mar-05 \\
\hline Arclight Capital & Investment & CPV Wind & Jul-05 \\
\hline Diamond Castle & Acquisition & Catamount & Oct-05 \\
\hline Pacific Hydro & Investment & Western Wind Energy & Oct-05 \\
\hline EIF U.S. Power Fund II & Investment & Tierra Energy, LLC & Dec-05 \\
\hline Airtricity & Acquisition & Renewable Generation Inc. & Dec-05 \\
\hline Babcock \& Brown & Acquisition & G3 Energy LLC & Jan-06 \\
\hline Iberdrola & Acquisition & Community Energy Inc. & Apr-06 \\
\hline Shaw/Madison Dearborn & Investment & UPC Wind & May-06 \\
\hline NRG & Acquisition & Padoma & Jun-06 \\
\hline CPV Wind & Acquisition & Disgen & Jul-06 \\
\hline BP & Investment & Clipper & Jul-06 \\
\hline BP & Acquisition & Greenlight & Aug-06 \\
\hline Babcock \& Brown & Acquisition & Superior & Aug-06 \\
\hline Enel & Investment & TradeWind & Sep-06 \\
\hline Iberdrola & Acquisition & Midwest Renewable Energy Corp. & Oct-06 \\
\hline Iberdrola & Acquisition & PPM (Scottish Power) & Dec-06 \\
\hline BP & Acquisition & Orion Energy & Dec-06 \\
\hline Naturener & Acquisition & Great Plains Wind \& Energy, LLC & Feb-07 \\
\hline HSH Nordbank & Investment & Ridgeline Energy & Feb-07 \\
\hline Energias de Portugal & Acquisition & Horizon & Mar-07 \\
\hline Iberdrola & Acquisition & CPV Wind & Apr-07 \\
\hline Duke Energy & Acquisition & Tierra Energy, LLC & May-07 \\
\hline Acciona & Acquisition & EcoEnergy, LLC & Jun-07 \\
\hline Babcock \& Brown & Acquisition & Bluewater Wind & Sep-07 \\
\hline Good Energies & Investment & EverPower & Sep-07 \\
\hline E.ON AG & Acquisition & Airtricity North America & Oct-07 \\
\hline Wind Energy America & Acquisition & Boreal & Oct-07 \\
\hline Marubeni & Investment & Oak Creek Energy Systems & Dec-07 \\
\hline NTR & Investment & Wind Capital Group & Apr-08 \\
\hline Canadian Pension Plan & Investment & Noble Power & Apr-08 \\
\hline ArcLight and Terra-Gen & Acquisition & Allco Wind Energy & Jun-08 \\
\hline Duke Energy & Acquisition & Catamount & Jun-08 \\
\hline Veolia & Acquisition & Ridgeline Energy & Oct-08 \\
\hline Riverstone Holdings & Acquisition & Babcock \& Brown & Jun-09 \\
\hline Terra Firma & Acquisition & Everpower Wind & Aug-09 \\
\hline APEX Wind Energy & Acquisition & BQ Energy, LLC & Jun-09 \\
\hline Global Infrastructure Partners & Investment & Terra-Gen Power Holdings & Nov-09 \\
\hline NRG Energy & Acquisition & Bluewater Wind & Nov-09 \\
\hline Enel & Investment & Geronimo Wind & Nov-09 \\
\hline
\end{tabular}


A number of large companies have entered the U.S. wind project development business in recent years, some through acquisitions and investments as highlighted in Table 7, and others through their own development activity or through joint development agreements with others. Particularly striking in recent years has been the entrance of large European energy companies, as well as the increased interest of U.S. utility affiliates in wind project development.

\section{Treasury Cash Grant Expands Financing Options, Buoys the Wind Sector}

Due to the global credit crisis, wind power project financing in the United States declined precipitously at the close of 2008, with many lenders and tax equity investors sidelined by extreme uncertainty and shrinking tax capacity. By mid-February of 2009, however, the U.S. Congress had passed the Recovery Act, parts of which were intended to alleviate financial constraints on the industry. Most notably, Section 1603 of the Recovery Act enables wind (and other qualifying) power projects to temporarily choose a $30 \%$ cash grant administered by the U.S. Treasury in lieu of either the PTC or a $30 \%$ investment tax credit (ITC). Title IV of the Recovery Act also expands an existing federal loan guarantee program administered by DOE to renewable energy projects using commercially proven (rather than just innovative) technology.

By replacing the PTC with an up-front 30\% cash grant, Section 1603 greatly reduces, but does not completely eliminate, the dependence of wind project developers on third-party tax equity investors. Tax appetite from outside of the project itself is still needed to efficiently use accelerated depreciation deductions in the year that they are generated. Many developers, however, have found that financing their projects with low-cost debt rather than more-expensive tax equity can more-than-make-up-for the value lost from carrying forward depreciation deductions until they can be fully used within the project itself.

The Section 1603 cash grant program has been heavily subscribed by the industry. Owners of more than 6,400 MW - i.e., more than $64 \%$ - of the wind power capacity installed in 2009 elected the grant in lieu of the PTC. As much as 2,400 MW of this capacity may not have been built in 2009 had the cash grant not been available (Bolinger et al. 2010). And in another sign that Section 1603 has accomplished its goal of reducing dependence on the tax equity market, only about seven of the more-than-sixty 2009 projects that elected the grant were financed using third-party tax equity (Chadbourne \& Parke 2010a); many of the rest substituted project-level term debt for third-party tax equity (and are presumably planning to carry forward unused depreciation deductions), while still others were built by developers that have their own internal tax appetite.

At present, wind power projects must be under construction by the end of 2010, and online by the end of 2012, in order to qualify for the grant. Congress is considering several bills that would extend the grant program in some form or fashion, and one oft-cited rationale for an extension is that the tax equity market has not yet recovered sufficiently to supply the amount of capital that the market would otherwise require. As of May 2010, there were roughly a dozen tax equity investors active in the wind power market - up from the handful of investors that maintained their presence throughout 2009, but still down from the market heights of early 2008 (Stolarski et al. 2010, Martin 2010). That said, as of June 2010, more than $\$ 2$ billion of tax 
equity had reportedly been invested in the wind power sector since the start of the year-more than was invested throughout all of 2009 - and the market was considered to be on pace to reach tax equity investment levels seen in the peak year of 2007 (Chadbourne \& Parke 2010b).

Although the tax equity market may still be somewhat constrained, capital has been flowing more-freely in the debt market, both from banks and institutional lenders. So-called "miniperms" (i.e., term debt with a balloon payment due in 5-7 years) dominated for much of 2009, though tenors began to lengthen somewhat as the year progressed. By early 2010, fully amortizing loans were once again seen in the market, some with tenors as long as 15-17 years. Spreads remain high - as high as 350 basis points above LIBOR in early 2010, compared to just 125 basis points a few years ago - but were reportedly under downward pressure in mid-2010 as the number of banks active in the wind power market increased to more than thirty (Zaelke et al. 2010), and in fact had fallen below 300 basis points according to some sources (Chadbourne \& Parke 2010b).

The rebound in the debt market is just one reason that there has been relatively weak demand for the federal loan guarantee program that was created as part of the Energy Policy Act of 2005 and expanded by the Recovery Act to include projects using commercially proven technologies. Other oft-cited reasons that the Section 1703 (for projects using innovative technology) and Section 1705 (for projects using commercially proven technology) loan guarantee programs have not been more popular include the relatively slow initial implementation of these programs, challenging application requirements (including the need to for a federal environmental review and complying with the Davis-Bacon Wage Act), initial inflexibility with regard to financing structures involving third-party tax equity, and the additional complexities and time to close that come from having another party - DOE - at the bargaining table (Bailey 2010, Zaelke et al. 2010, Stolarski et al. 2010, Chadbourne \& Parke 2010b). By mid-July 2010, just two windrelated loan guarantees had been awarded under the Section 1703 program: Nordic Windpower received a $\$ 16$ million loan guarantee to expand its wind turbine manufacturing facility in Pocatello, Idaho, while First Wind received a \$117 million loan guarantee for its $30 \mathrm{MW}$ Kahuku wind project (which includes battery storage) in Hawaii. No wind power project has yet been awarded a guarantee under the Section 1705 program for commercial technologies, but that program could be particularly useful for larger wind power projects that can spread the transaction costs over more capacity, and that might otherwise be too large to raise debt financing through the normal channels (Zaelke et al. 2010, Stolarski et al. 2010, Chadbourne \& Parke 2010b).

\section{IPP Project Ownership Remained Dominant, but Utility Ownership Increased}

Independent power producers (IPPs) continued to dominate the ownership of wind power projects in 2009, owning 83\% (8,247 MW) of all new capacity additions (Figure 17). Nearly $16 \%$ of the total wind power capacity additions in 2009 are owned by local electric utilities, with investor-owned utilities (IOUs) owning 1,057 MW and publicly owned utilities (POUs) owning another $510 \mathrm{MW}$. Community wind power projects - defined here as projects using turbines over $100 \mathrm{~kW}$ in size and completely or partly owned by towns, schools, commercial customers, 
or farmers, but excluding publicly owned utilities - constitute the remaining $2 \%$ of new capacity, with $180 \mathrm{MW}$. Of the cumulative installed wind power capacity at the end of 2009, IPPs owned $83 \%(29,164 \mathrm{MW})$, with utilities contributing 15\% (4,265 MW for IOUs and 1,071 MW for POUs), and community ownership just $2 \%$ (656 MW).
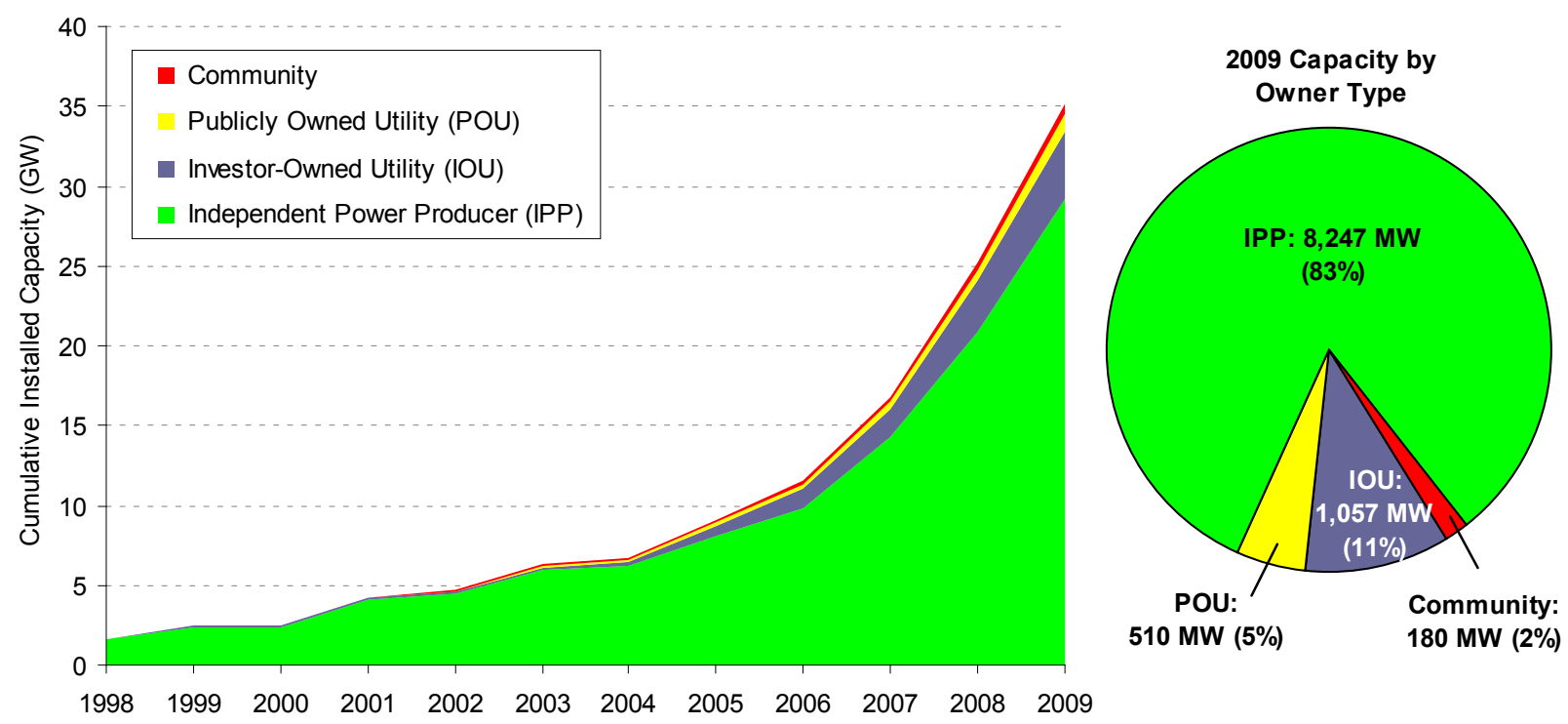

Source: Berkeley Lab estimates based on AWEA project database

Figure 17. Cumulative and 2009 Wind Power Capacity Categorized by Owner Type

The dominance of IPP ownership, and the more recent trend towards increased utility ownership, has been driven by several factors. Up until the Internal Revenue Service (IRS) clarified the issue in 2005, some IOUs were uncertain as to whether they could claim the PTC on utilityowned wind power projects (due to the requirement that PTC-eligible power must be sold to an unrelated party - in 2005 the IRS clarified that ratepayers are indeed unrelated parties). More broadly, when wind energy was a small part of the generation mix, some utilities felt that buying wind power was less risky than owning wind power projects. As utilities have gained comfort with wind power over the years, however, their interest in ownership has increased for several reasons: IOUs are typically allowed to earn a regulated return on project ownership (i.e., by adding it to their rate base) but not on power purchases; credit rating agencies have at times considered long-term power purchase agreements to be debt-like instruments, thereby potentially negatively impacting a utility's credit rating; and ownership places the utility in a position of greater control over the cost and price of wind energy that it receives. As a result of these drivers, utility ownership of wind power projects may continue to increase in the coming years. 


\section{Long-Term Contracted Sales to Utilities Remained the Most Common Sales Arrangement, but Merchant Plants Were Surprisingly Abundant in 2009}

Electric utilities continued to be the dominant purchasers of wind power (see Figure 18), with $58 \%$ of the new 2009 capacity selling electricity under long-term power purchase agreements (PPAs) to either IOUs (36\%) or POUs (22\%). In aggregate, these two types of utilities buy power from $62 \%$ of the cumulative wind power capacity in the United States (IOUs purchase $44 \%$ and POUs purchase $18 \%$ ).
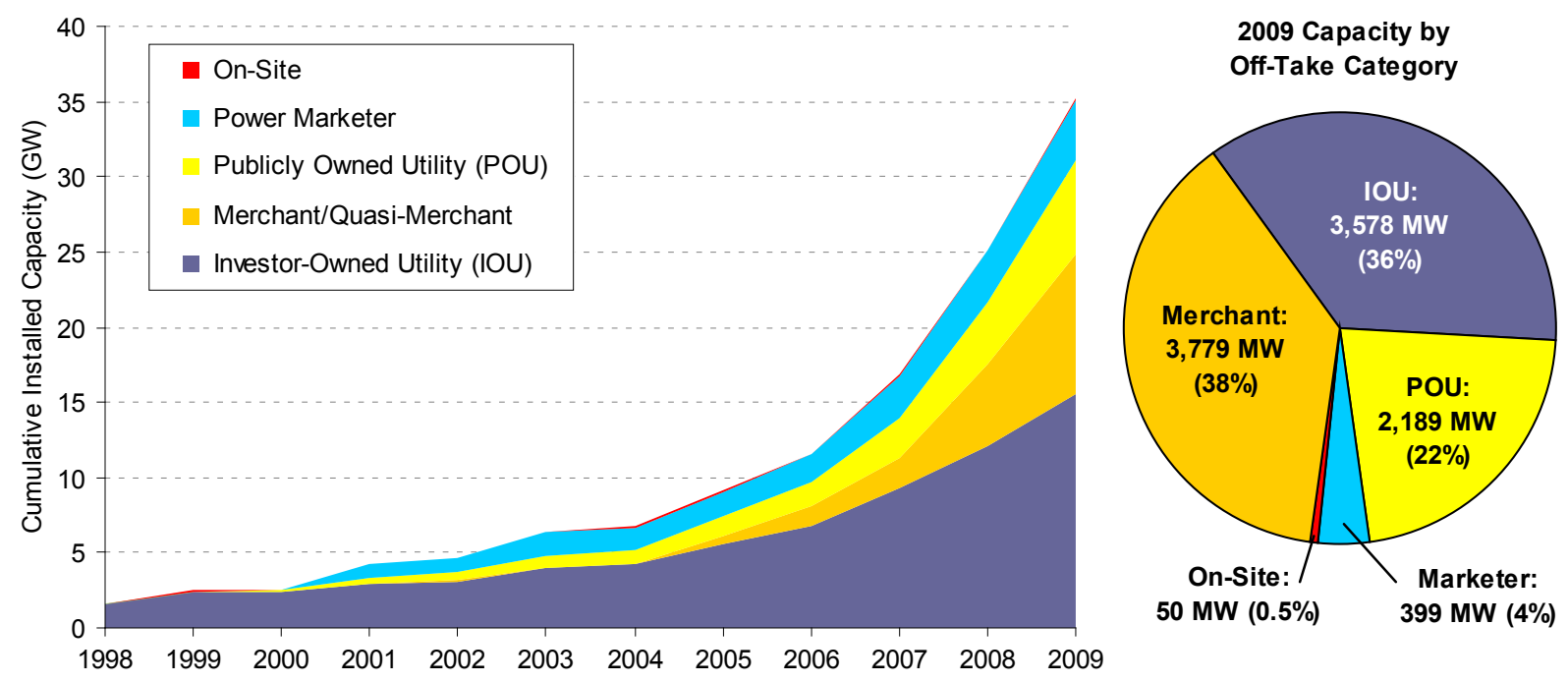

Source: Berkeley Lab estimates based on AWEA project database

\section{Figure 18. Cumulative and 2009 Wind Power Capacity Categorized by Power Off-Take Arrangement}

Surprisingly, merchant/quasi-merchant projects were also in abundance in 2009, accounting for $38 \%$ of all new capacity (and $26 \%$ of cumulative capacity). Merchant/quasi-merchant projects are those whose electricity sales revenue is tied to short-term contracted and/or wholesale spot electricity market prices (with the resulting price risk commonly hedged over a 5- to 10-year period $^{33}$ ) rather than being locked in through a long-term PPA. Expectations for merchant development in 2009 had been low at the start of the year, due to very tight credit and sharply lower wholesale electricity prices. In fact, it is possible that many projects that sold power on a merchant basis in 2009 may now be seeking longer-term PPAs in order to gain increased revenue stability. Regardless, the amount of merchant/quasi-merchant sales in 2009 was significant, with approximately $72 \%$ of that activity in Texas (45\%), New York (15\%), and Illinois (12\%) - i.e., states in which wholesale spot electricity markets exist, where wind power has (at least prior to 2009) been able to compete with those prices, and where additional revenue may be possible from the sale of renewable energy certificates (RECs).

\footnotetext{
${ }^{33}$ Hedges are often structured as a "fixed-for-floating" power price swap - a purely financial arrangement whereby the wind power project swaps the "floating" revenue stream that it earns from spot power sales for a "fixed" revenue stream based on an agreed-upon strike price. For some projects (especially where natural gas is virtually always the marginal supply unit), the hedge is structured in the natural gas market rather than the power market, in order to take advantage of the greater liquidity and longer terms available in the forward gas market.
} 
The role of power marketers - defined here as corporate intermediaries that purchase power under contract and then re-sell that power to others, sometimes taking some merchant risk ${ }^{34}-$ in the wind power market has waned somewhat in recent years. In 2009, power marketers purchased the output of just $4 \%$ of the new wind power capacity, with $11 \%$ of the cumulative capacity selling to power marketers.

Finally, roughly $50 \mathrm{MW}$ of the wind power additions in 2009 that used turbines over $100 \mathrm{~kW}$ in size were interconnected on the customer side of the utility meter, with the power being consumed on site rather than sold.

\footnotetext{
${ }^{34}$ Power marketers are defined here to include not only traditional marketers such as PPM Energy (now part of Iberdrola), but also the wholesale power marketing affiliates of large investor-owned utilities (e.g., PPL Energy Plus or FirstEnergy Solutions), which may buy wind power on behalf of their load-serving affiliates.
} 


\section{Price, Cost, and Performance Trends}

\section{Upward Pressure on Wind Power Prices Continued in 2009}

Although some of the cost pressures facing the industry in recent years (e.g., rising materials costs, the weak dollar, turbine and component shortages) have eased somewhat, it will take time before relief flows through the project development pipeline to impact overall average wind power prices. After all, projects built in 2009 may have purchased turbines in 2007 or 2008, and may have established contractual pricing terms at a similar point in time. As such, 2009 was another year of rising wind power prices.

Berkeley Lab collects data on wind power sales prices from the sources listed in the Appendix, resulting in a dataset that consists of price data for 180 wind power projects installed between 1998 and the end of 2009. These projects total $12,813 \mathrm{MW}$, or $38 \%$ of the wind power capacity brought on line in the United States over the 1998-2009 timeframe. ${ }^{35}$ The dataset excludes merchant plants and projects that sell renewable energy certificates (RECs) separately. The prices in the dataset therefore reflect the bundled price of electricity and RECs as sold by the project owner under a power purchase agreement. Because these prices are suppressed by the receipt of available state and federal incentives (e.g., the prices reported here would be at least \$20/MWh higher without the PTC / ITC / Treasury Grant), they do not represent wind energy generation costs.

Based on these data, the capacity-weighted average power sales price from the sample of post1997 wind power projects remains relatively low by historical standards, but has been steadily increasing in recent years. Figure 19 shows the cumulative capacity-weighted average wind power price (along with the range of individual project prices falling between the $25^{\text {th }}$ and $75^{\text {th }}$ percentiles) in each calendar year from 1999 through 2009. Based on the limited sample of 7 projects built in 1998 or 1999 and totaling $450 \mathrm{MW}$, the weighted-average price of wind energy in 1999 was $\$ 65 / \mathrm{MWh}$ (expressed in 2009 dollars). By 2009, in contrast, the cumulative sample of projects built from 1998 through 2009 had grown to 180 projects totaling 12,813 MW, with an average price of $\$ 45 / \mathrm{MWh}$ (with $50 \%$ of individual project prices falling between $\$ 33 / \mathrm{MWh}$ and $\$ 53 / \mathrm{MWh}){ }^{36}$ Although Figure 19 does show a modest increase in the weighted-average wind power price since 2005 , reflecting rising prices from new projects, the cumulative nature of the graphic mutes the degree of increase.

\footnotetext{
${ }^{35}$ Three primary factors significantly restrict the size of this sample: (1) projects located within ERCOT (in Texas) fall outside of FERC's jurisdiction, and are therefore not required to report prices (reduces sample by about 8,600 $\mathrm{MW})$; (2) the increasing number of utility-owned projects are not included, since these projects do not sell their power on the wholesale market (reduces sample by about 5,300 MW); and (3) the increasing number of merchant (or quasi-merchant) projects that sell power and RECs separately are not included in the sample, because the power price reported by these projects only represents a portion of total revenue received (reduces sample by roughly another 4,200 MW). In addition, certain "qualifying facilities" are not required to report their power sales to FERC.

${ }^{36}$ All wind power pricing data presented in this report exclude the few projects located in Hawaii. Those projects are considered outliers in that they are significantly more expensive to build than projects in the continental United States, and receive a power sales price that is significantly higher-than-normal, in part because it has historically been linked to the price of oil.
} 


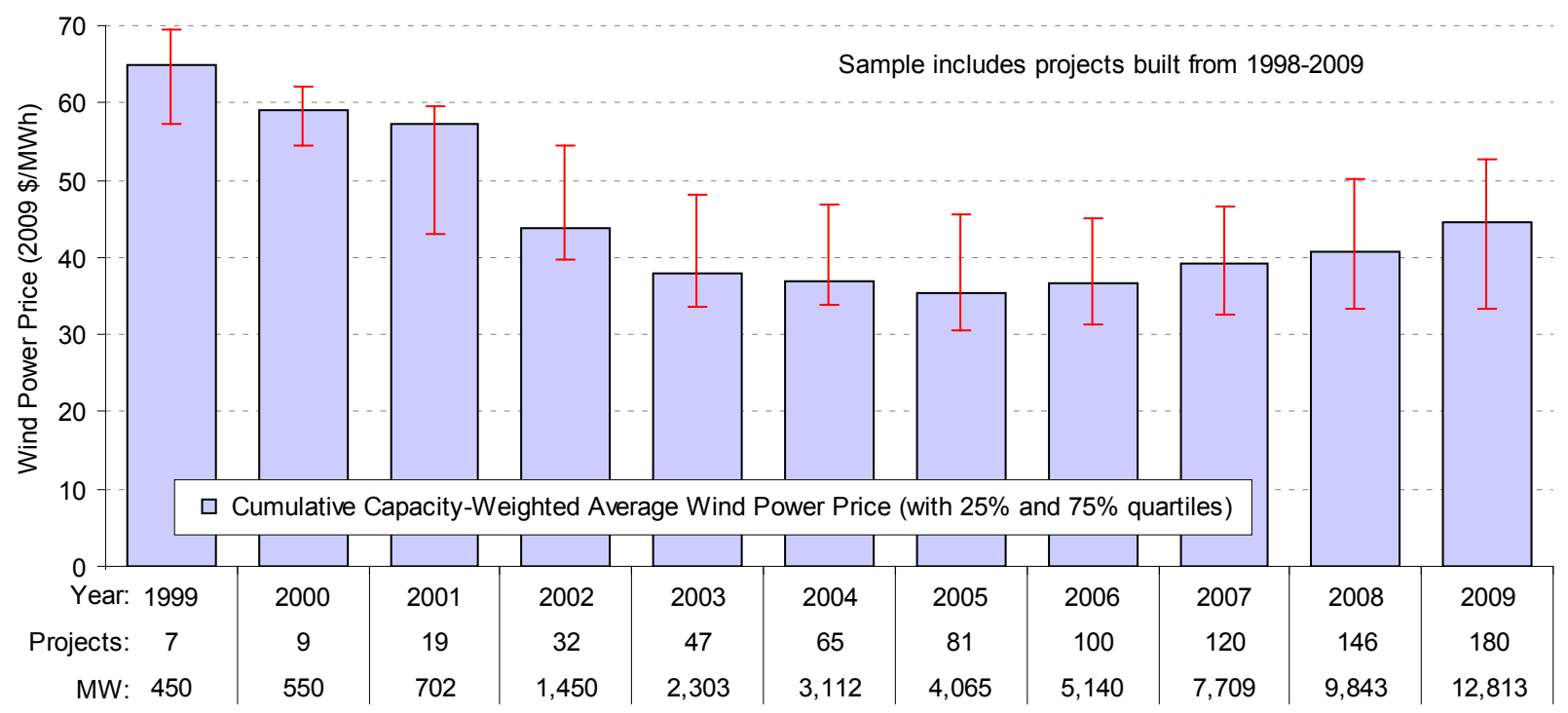

Source: Berkeley Lab

\section{Figure 19. Cumulative Capacity-Weighted Average Wind Power Prices Over Time}

To better illustrate changes in the price of power from newly built wind power projects, Figure 20 shows average wind power sales prices in 2009 , grouped by project vintage (i.e., by each project's initial commercial operation date).$^{37}$ Although the limited project sample and the considerable variability in prices across projects installed in a given time period complicate analysis of national price trends (with averages subject to regional and other factors), the general trend exhibited by the capacity-weighted-average prices (i.e., the blue columns) nevertheless shows that prices bottomed out for projects built in 2002 and 2003, and have since risen significantly. ${ }^{38}$ Specifically, the capacity-weighted average 2009 sales price, based on projects in the sample built in 2009 , was roughly $\$ 61 / \mathrm{MWh}$, up from an average of $\$ 51 / \mathrm{MWh}$ for the sample of projects built in 2008, and nearly double the average of $\$ 32 / \mathrm{MWh}$ among projects built during the low point in 2002 and 2003.

\footnotetext{
${ }^{37}$ Prices from two individual projects built during the 2000-2001 period, and one project built in 2008, are not shown in Figure 20 (due to the scale of the y-axis), but are included in the capacity-weighted averages for those periods. The omitted prices are roughly $\$ 95 / \mathrm{MWh}$ and $\$ 150 / \mathrm{MWh}$ in the earlier period, and $\$ 126 / \mathrm{MWh}$ for the 2008 project.

${ }^{38}$ Although it may seem counterintuitive, the weighted-average price in 1999 for projects built in 1998 and 1999 (shown in Figure 19 to be about $\$ 65 / \mathrm{MWh}$ ) is significantly higher than the weighted-average price in 2009 for projects built in 1998 and 1999 (shown in Figure 20 to be about \$33/MWh) for three reasons: (1) the sample size is larger in Figure 20, due to the fact that 2009 prices are presented, rather than 1999 prices as in Figure 19 (i.e., we were unable to obtain early-year pricing for some of the projects built in 1998-1999); (2) two of the larger projects built in 1998 and 1999 (for which both 1999 and 2009 prices are available, meaning that these projects are represented within both figures) have nominal PPA prices that actually decline, rather than remaining flat or escalating, over time; and (3) inflating all prices to constant 2009 dollar terms impacts older (i.e., 1999) prices more than it does more-recent (i.e., 2009) prices.
} 


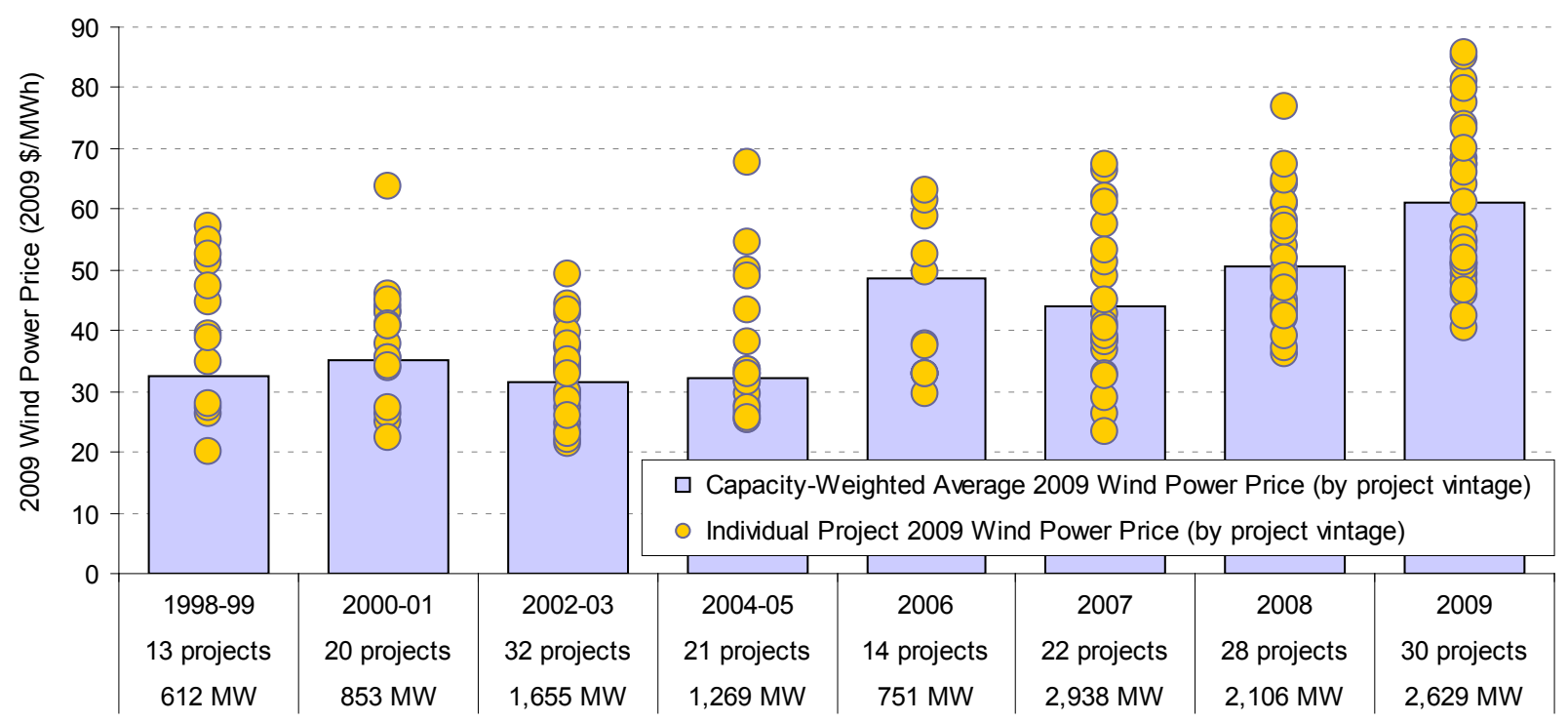

Source: Berkeley Lab database

\section{Figure 20. 2009 Wind Power Prices by Project Vintage}

The underlying variability in wind power prices within a year is caused in part by regional factors, which may affect not only project capacity factors (depending on the strength of the wind resource in a given region), but also development and installation costs (depending on a region's physical geography, population density, labor rates, or even regulatory processes). It is also possible that regions with higher wholesale electricity prices or with greater demand for renewable energy will, in general, yield higher wind energy contract prices due to market factors.

Figure 21 shows individual project and average 2009 wind power prices by region for just those wind power projects installed from 2006-2009 (i.e., the more-recent period of higher prices, as shown in Figure 20), with regions as defined in Figure 22. Although sample size is quite small and therefore problematic in numerous regions, Texas and the Heartland region appear to be among the lowest price areas on average, while New England, California, and the East are among the higher price regions. ${ }^{39}$

\footnotetext{
${ }^{39}$ Average prices in Texas and New England, in particular, may not be representative as those averages include just three and two projects, respectively. Once again, sample size in Texas is severely limited (despite the enormous growth of wind power capacity in that state) because generators located within ERCOT are not required to file pricing information with FERC. As such, the pricing information for Texas provided in this report comes primarily from projects located in the Texas panhandle, which is within the Southwest Power Pool (SPP) rather than ERCOT. Note also that projects in this area have not experienced the same level of curtailment as is common in ERCOT which, in combination with a strong wind resource in the region and relatively low capital costs (two of the three projects, totaling $75 \%$ of the aggregate capacity, were built earlier in the 2006-2009 time period), may have facilitated lower prices than in other parts of Texas. One of the two New England projects in the sample over this period is not shown in Figure 21 because its price $(\$ 126 / \mathrm{MWh})$ exceeds the scale of the $y$-axis; however, this project's price is included in the capacity-weighted average for New England.
} 


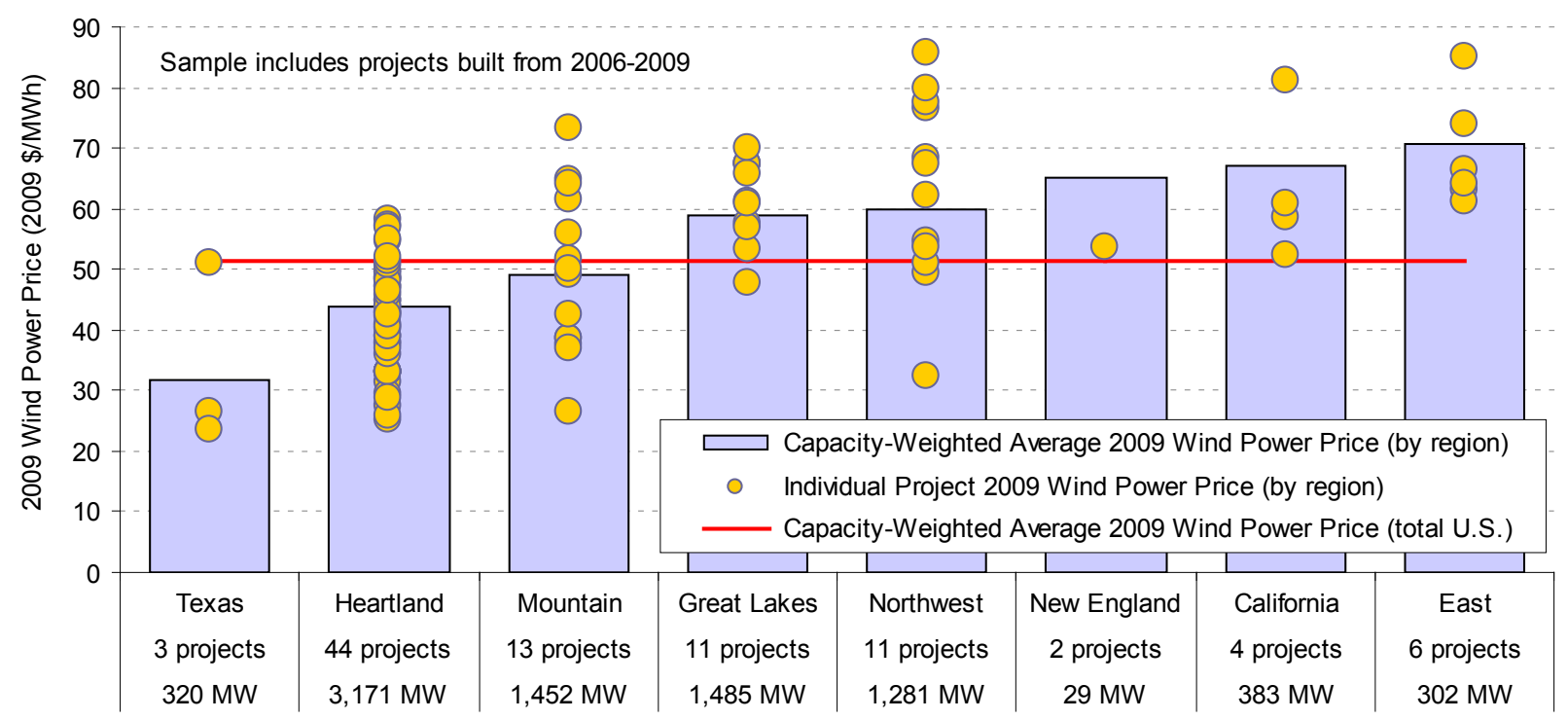

Source: Berkeley Lab

Figure 21. 2009 Wind Power Prices by Region: 2006-2009 Projects Only

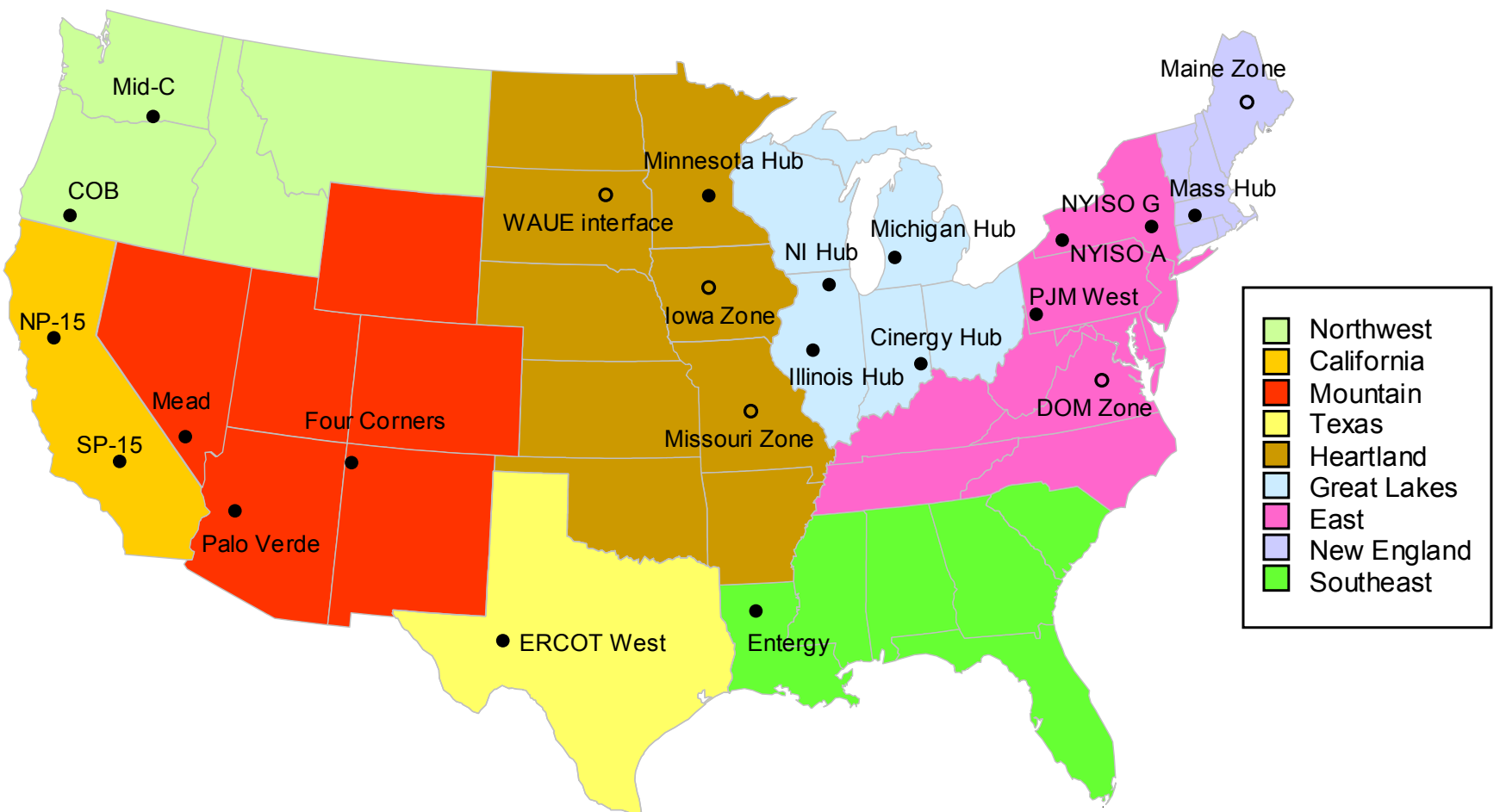

Note: The pricing nodes represented by an open, rather than closed, bullet do not have complete pricing history back through 2003.

Figure 22. Map of Regions and Wholesale Electricity Price Hubs Used in Analysis 


\section{REC Markets Remain Fragmented, with a Wide Range of Pricing}

The wind power sales prices presented in this report reflect only the bundled sale of both electricity and RECs; excluded are projects that sell RECs separately from electricity, thereby generating two sources of revenue. REC markets are highly fragmented in the United States, but consist of two distinct segments: compliance markets in which RECs are purchased to meet state RPS obligations, and green power markets in which RECs are purchased on a voluntary basis.

The figures below present indicative monthly data of spot-market REC prices in both compliance and voluntary markets, grouped into High-Price and Low-Price markets; data for compliance markets focus on the "Class I" or "Main Tier" of the RPS policies. Clearly, spot REC prices have varied substantially, both among states and over time within individual states. Among compliance markets in the Northeast, prices for RECs used to serve RPS requirements in Connecticut, Massachusetts, and Rhode Island remained relatively flat in 2009, following a steep drop in 2008, while prices in the new RPS compliance markets in New Hampshire and Maine were at levels consistent with the other Northeastern states. REC prices to serve RPS requirements in New Jersey, Illinois, and Delaware remained relatively flat during the latter half of the 2009, after declining earlier in the year. REC prices remained relatively low in several other compliance markets (Texas, Maryland, Pennsylvania, and Washington D.C.) due to a surplus of eligible renewable energy supply relative to RPS-driven demand in those markets. Prices for RECs offered in voluntary markets in 2009 ranged from an annual average of less than $\$ 2 / \mathrm{MWh}$ for national voluntary wind RECs (which continue to closely track the price of Texas RECs) to approximately \$7/MWh for voluntary wind RECs in the West.
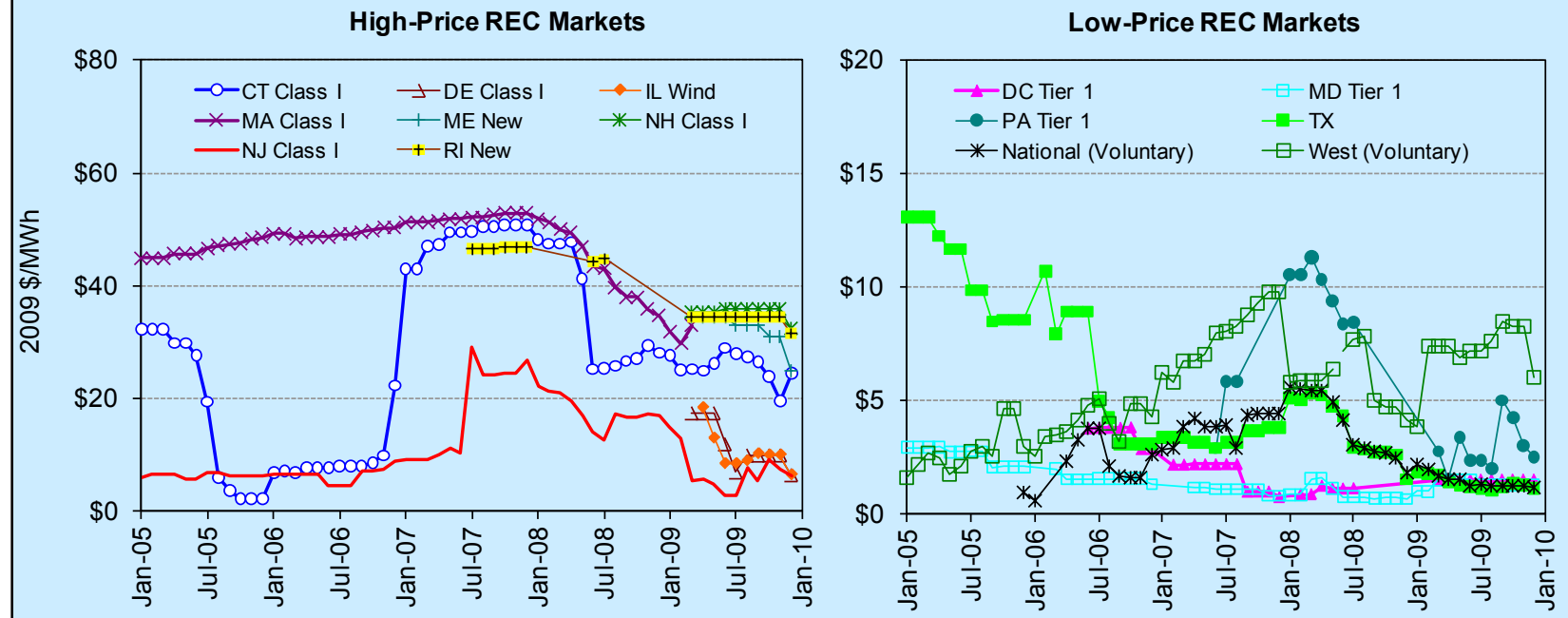

Sources: Evolution Markets and Spectron. Plotted prices represent the price of the last monthly trade (if available), or the midpoint of Bid and Offer prices, for the current or nearest compliance year.

\section{Sharp Drop in Wholesale Electricity Prices Makes the Near-Term Economics of Wind Energy More Challenging}

A simple comparison of the wind power prices presented in the previous section to recent wholesale electricity prices throughout the United States demonstrates that while wind power had consistently been priced (on average) at the low end of the range of wholesale electricity prices going back through 2003, the drop in wholesale electricity prices in 2009 pushed wind energy to the top of that range. Specifically, Figure 23 shows the range (minimum and 
maximum) of average annual wholesale electricity prices for a flat block of power ${ }^{40}$ going back to 2003 at twenty-three different pricing nodes located throughout the country (refer to Figure 22 for the names and approximate locations of the twenty-three pricing nodes represented by the blue-shaded area ${ }^{41}$ ). The red dots show the cumulative capacity-weighted average price received by wind power projects in each year among those projects in the sample with commercial operation dates of 1998 through 2009 (consistent with the data first presented in Figure 19).

At least on a cumulative basis within the sample of projects reported here, average wind power prices compared favorably to wholesale electricity prices from 2003 through 2008 . The increase in wind power prices in 2009, however, combined with the deep reduction in wholesale electricity prices (driven by lower natural gas prices), reversed this long-term trend in 2009. Although low natural gas prices are, in part, attributable to the recession-induced drop in energy demand, the discovery and early development of significant shale gas deposits has resulted in reduced expectations for increases in natural gas prices going forward. As a result, natural gas prices may not rebound to earlier levels as the economy recovers, putting the near-term comparative economic position of wind energy at some risk (especially if wind energy costs do not also decrease - see a later section suggesting that cost reductions may be on the horizon).

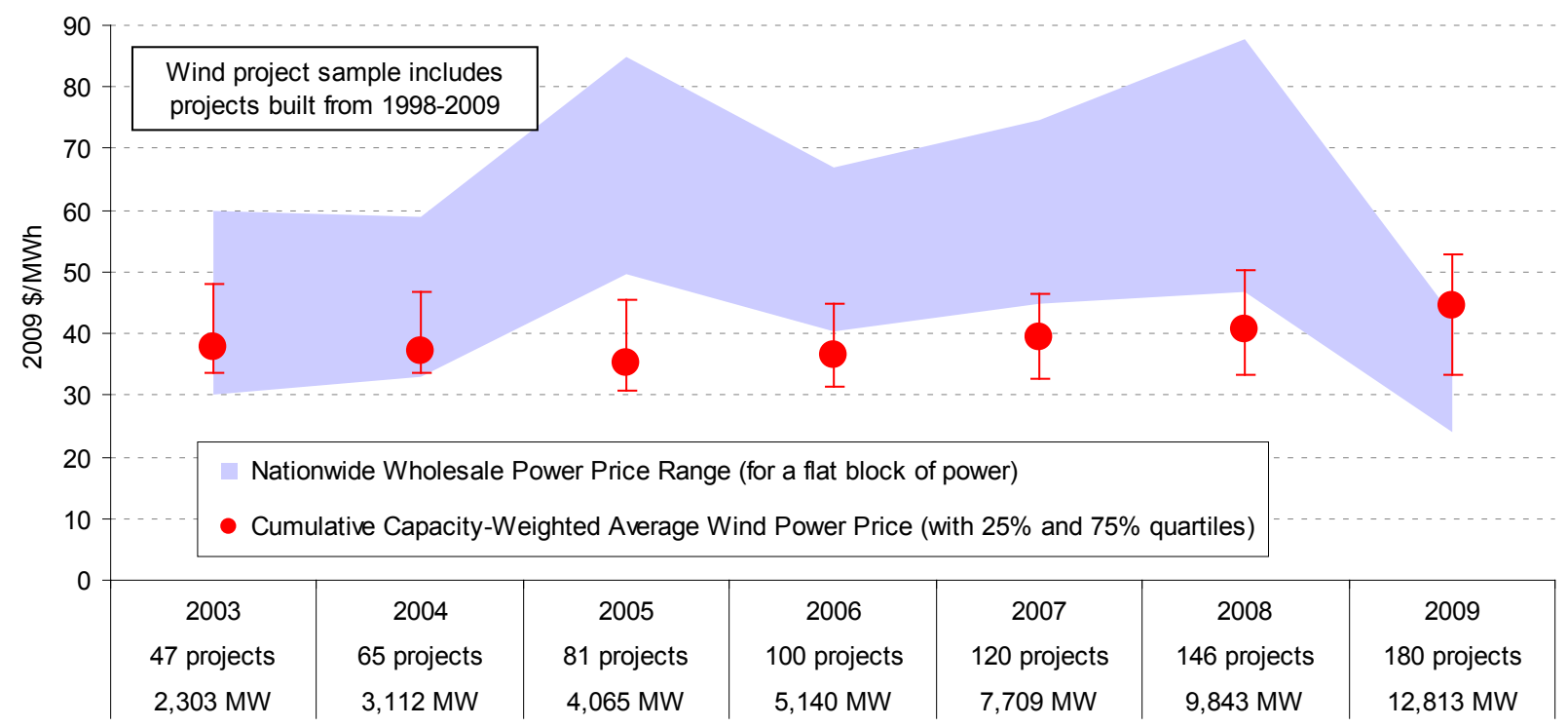

Source: Berkeley Lab, FERC, Ventyx, ICE

Figure 23. Average Cumulative Wind and Wholesale Electricity Prices Over Time

Though Figure 23 portrays a national comparison, there are clearly regional differences in wholesale electricity prices and in the average price of wind power. Moreover, as shown earlier

\footnotetext{
${ }^{40}$ A flat block of power is defined as a constant amount of electricity generated and sold over a specified time period. Though wind power projects do not provide a perfectly flat block of power, as a common point of comparison, a flat block is not an unreasonable starting point. In other words, the time-variability of wind energy is often such that its wholesale market value is somewhat lower than, but not too dissimilar from, that of a flat block of (non-firm) power.

${ }^{41}$ The five pricing nodes represented in Figure 22 by an open, rather than closed, bullet do not have complete pricing history back through 2003. As such, the wholesale electricity range presented in Figure 23 does not, in every year, reflect data from the complete set of hubs.
} 
in Figure 20, wind power prices have risen among more-recently built projects. Figure 24 accounts for both of these considerations by focusing on 2009 wind and wholesale electricity prices in the same regions as shown earlier, based only on the sample of wind power projects installed from 2006 through 2009 (i.e., the more-recent period of higher pricing, as shown earlier in Figure 20). ${ }^{42}$ Although there is quite a bit of variability within some regions, and several regions again have limited sample size, the spread between the average wind power and wholesale electricity prices (i.e., the wind power premium) in each region is fairly consistent across the United States, suggesting that the struggle for wind energy to compete in 2009 on short-term economics alone was indeed a nationwide phenomenon.

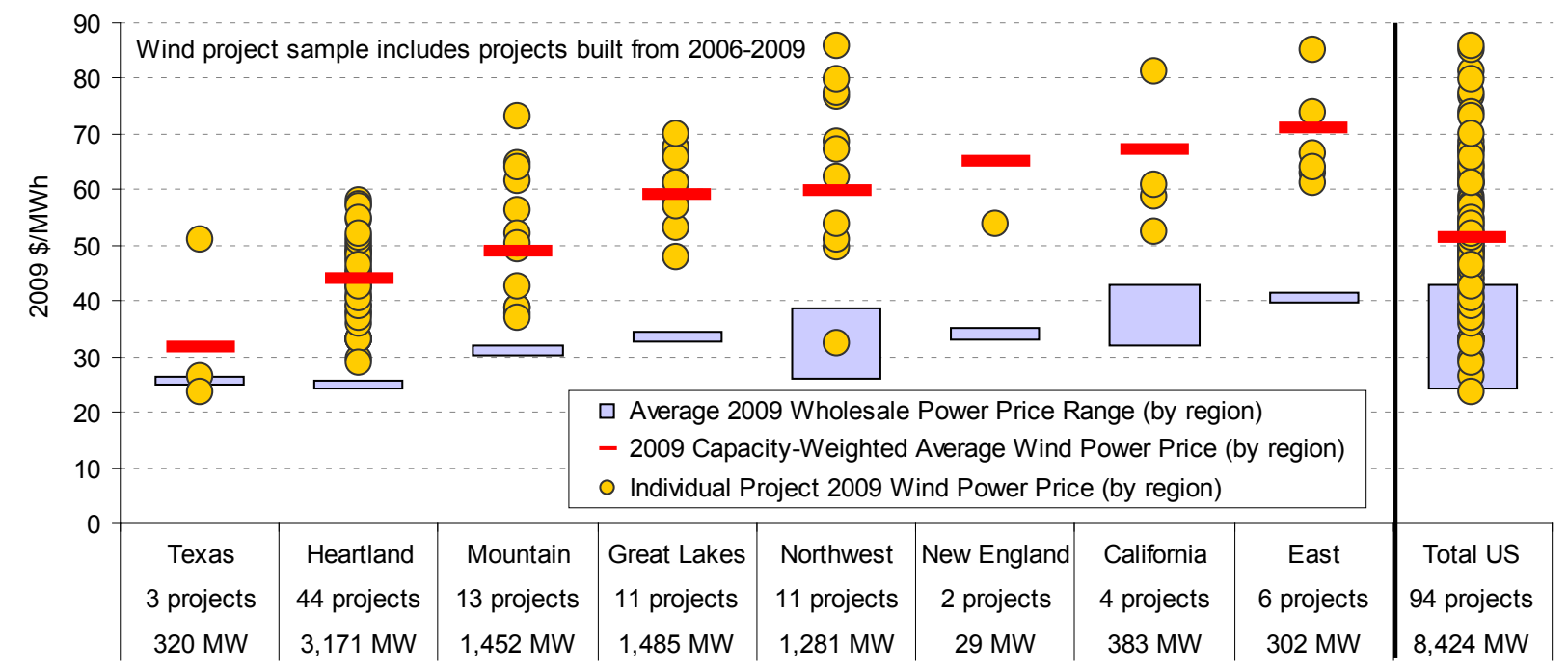

Source: Berkeley Lab, Ventyx, ICE

Figure 24. Wind and Wholesale Electricity Prices by Region: 2006-2009 Projects Only

Important Note: Notwithstanding the comparisons made in Figures 23 and 24, it should be recognized that neither the wind nor wholesale electricity prices presented in this section reflect the full social costs of power generation and delivery. Specifically, the wind power prices are suppressed by virtue of federal and, in some cases, state tax and financial incentives. Furthermore, these prices do not fully reflect integration, resource adequacy, or transmission costs. At the same time, wholesale electricity prices do not fully reflect transmission costs, may not fully reflect capital and fixed operating costs, and are suppressed by virtue of any financial incentives provided to fossil-fueled generation and by not fully accounting for the environmental and social costs of that generation. In addition, wind power prices - once established - are typically fixed and known (because wind energy is often sold through long-term, fixed-price power purchase agreements), whereas wholesale electricity prices are short-term and therefore subject to change over time. Finally, the location of the wholesale electricity nodes and the assumption of a flat-block of power are not perfectly consistent with the location and output profile of the sample of wind power projects.

\footnotetext{
${ }^{42}$ Although its price $(\$ 126 / \mathrm{MWh})$ is factored into the capacity-weighted average wind power price (depicted by the red dash), one New England project is not shown in Figure 24, due to the compressed y-axis scale. As discussed in footnote 39, the average wind energy prices for Texas and New England presented here should be viewed with caution.
} 
In short, comparing wind and wholesale electricity prices in this manner is not appropriate if one's goal is to fully account for the costs and benefits of wind energy relative to its competition. Another way to think of Figures 23 and 24, however, is as loosely representing the decision facing wholesale electricity purchasers that are otherwise under no obligation to purchase additional amounts of wind energy - i.e., whether to contract long-term for wind power or to buy a flat block of (non-firm) spot power on the wholesale electricity market. In this sense, the costs represented in Figures 23 and 24 are reasonably comparable, in that they represent (to some degree, at least) what the power purchaser would actually pay.

\section{Project Performance and Capital Costs Drive Wind Power Prices}

Wind power sales prices are affected by a number of factors, two of the most important of which are installed project costs and project performance. ${ }^{43}$ Figures 25 and 26 illustrate the importance of these two variables.

Figure 25 shows the relationship between project-level installed costs and power sales prices in 2009 for a sample of more than 10,500 MW of wind power projects installed in the United States from 1998 through 2009. ${ }^{44}$ Though the scatter is considerable, in general, projects with higher installed costs also have higher wind power prices.

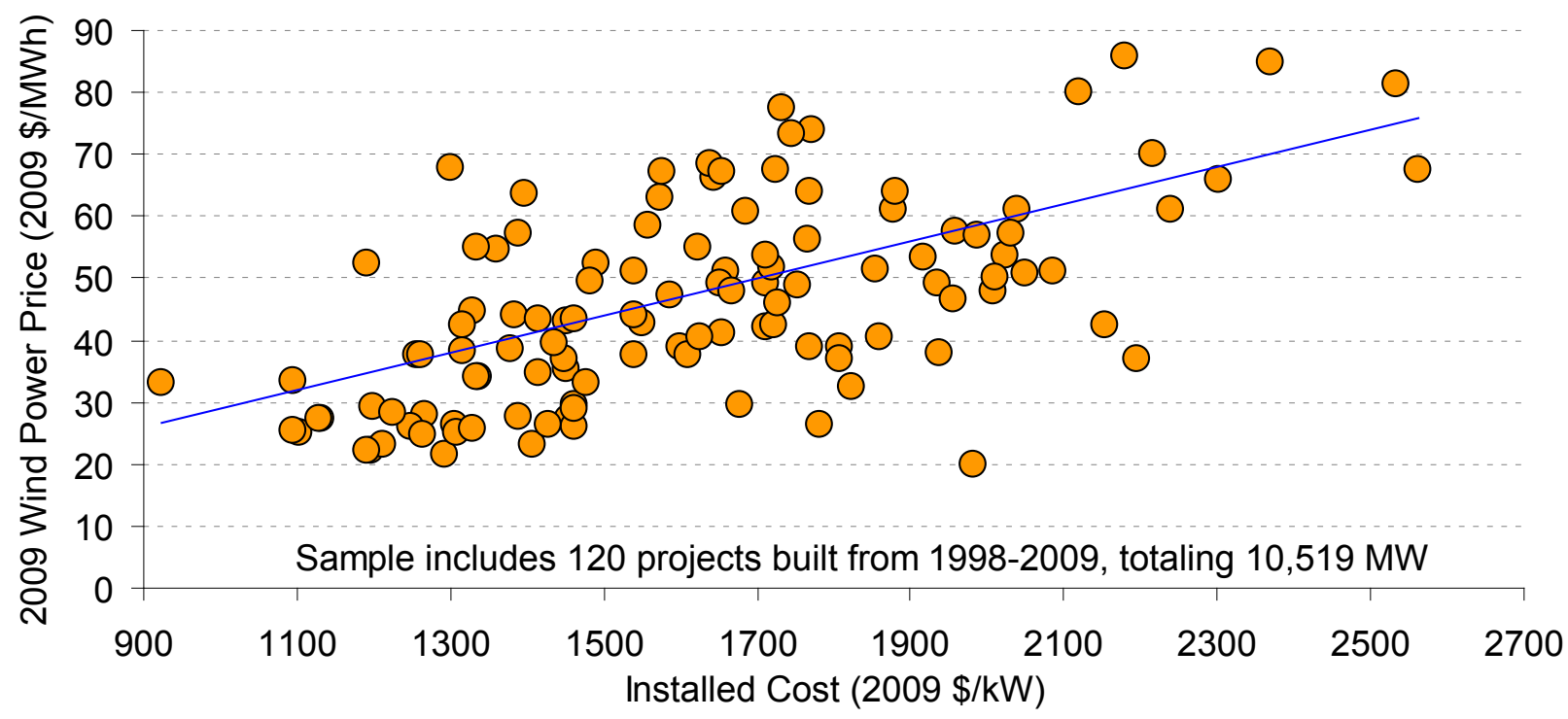

Source: Berkeley Lab

Figure 25. 2009 Wind Power Price as a Function of Installed Project Costs

\footnotetext{
${ }^{43}$ Operations and maintenance (O\&M) costs are another important variable that affects wind power prices. A later section of this report covers trends in project-level O\&M costs.

${ }^{44}$ In Figures 25 and 26, three individual project outliers (the same three described earlier in footnote 37 ) are obscured by the compressed y-axis scale, yet still influence the trend line.
} 
Figure 26 illustrates the relationship between project-level capacity factors in 2009 and power sales prices in that same year for a sample of more than 10,100 MW of wind power projects installed from 1998 through 2008. The inverse relationship shows that projects with higher capacity factors generally have lower wind power prices, though considerable scatter is again apparent.

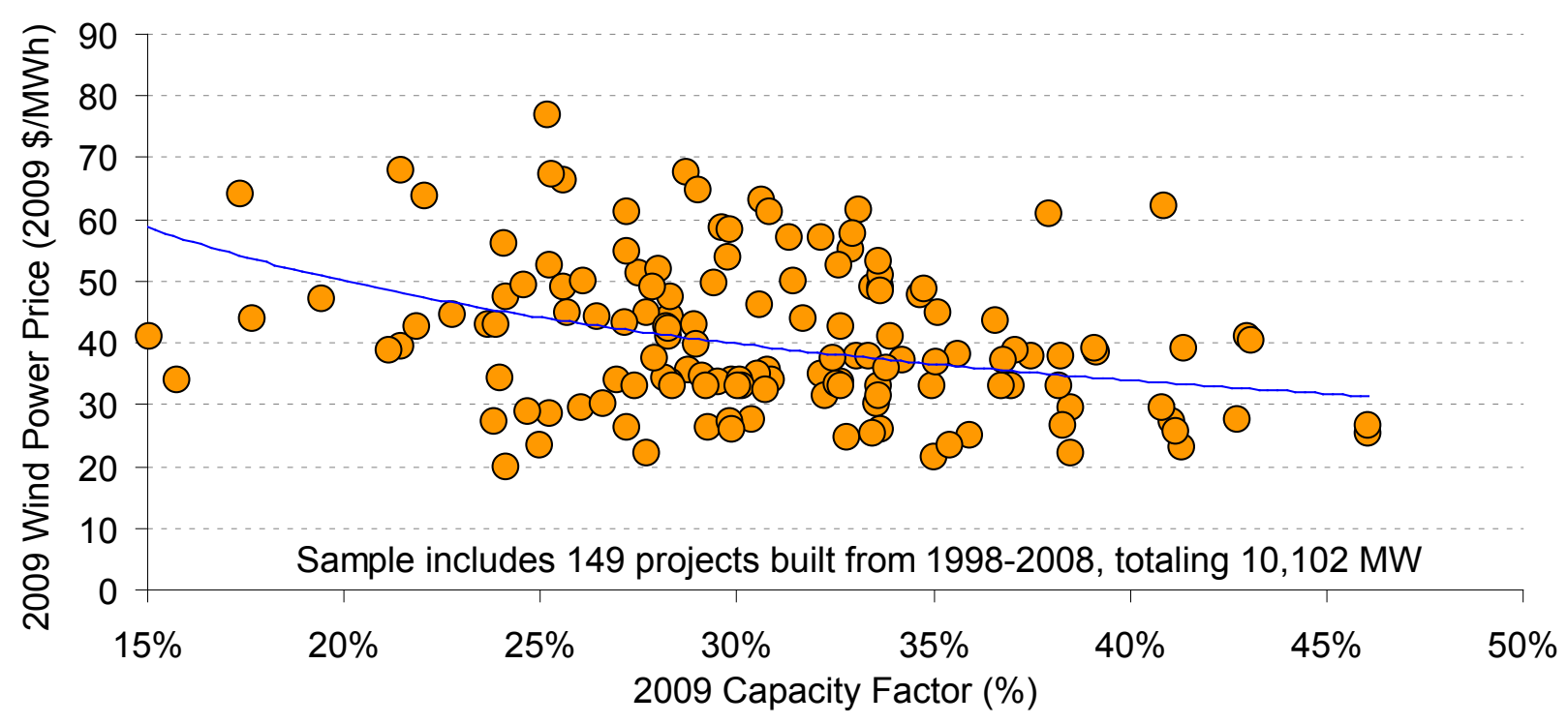

Source: Berkeley Lab

Figure 26. 2009 Wind Power Price as a Function of 2009 Capacity Factor

The next few sections of this report explore trends in installed costs and project performance in more detail, as both factors can have significant effects on wind power prices.

\section{The Installed Cost of Wind Power Projects Continued to Rise in 2009, but Reductions May Be on the Horizon}

Berkeley Lab compiles data on the installed cost of wind power projects in the United States, including data on 115 projects completed in 2009 totaling 9,656 MW, or $97 \%$ of the wind power capacity installed in that year. In aggregate, the dataset includes 405 completed wind power projects in the continental United States totaling $28,522 \mathrm{MW}$, and equaling roughly $81 \%$ of all wind power capacity installed in the United States at the end of 2009. In general, reported project costs reflect turbine purchase and installation, balance of plant, and any substation and/or interconnection expenses. Data sources are diverse, however, and are not all of equal credibility, so emphasis should be placed on overall trends in the data, rather than on individual project-level estimates.

As shown in Figure 27, the installed cost of wind power projects declined dramatically from the beginning of the industry in California in the 1980s through the early 2000s (falling by roughly 
$\$ 2,700 / \mathrm{kW}$ over this period ${ }^{45}$ ), but have more recently increased. ${ }^{46}$ Among the sample of projects built in 2009 , for example, the capacity-weighted average installed cost was $\$ 2,120 / \mathrm{kW}$. This average increased by $\$ 170 / \mathrm{kW}(9 \%)$ from the weighted-average cost of $\$ 1,950 / \mathrm{kW}$ for projects installed in 2008 , and increased by $\$ 820 / \mathrm{kW}(63 \%)$ from the average cost of projects installed from 2001 through 2004. Project costs have clearly risen, on average, over the last five years. ${ }^{47}$

Some of the cost pressures facing the industry in recent years (e.g., rising materials costs, the weak dollar, and turbine and component shortages) have eased since late 2008. As a result, while costs may - on average - remain high for a period of time as developers continue to work their way through the dwindling backlog of turbines purchased in early 2008 at peak prices under long-term frame agreements, ${ }^{48}$ there are expectations that average installed costs will decline over time (see next section, on wind turbine price trends).

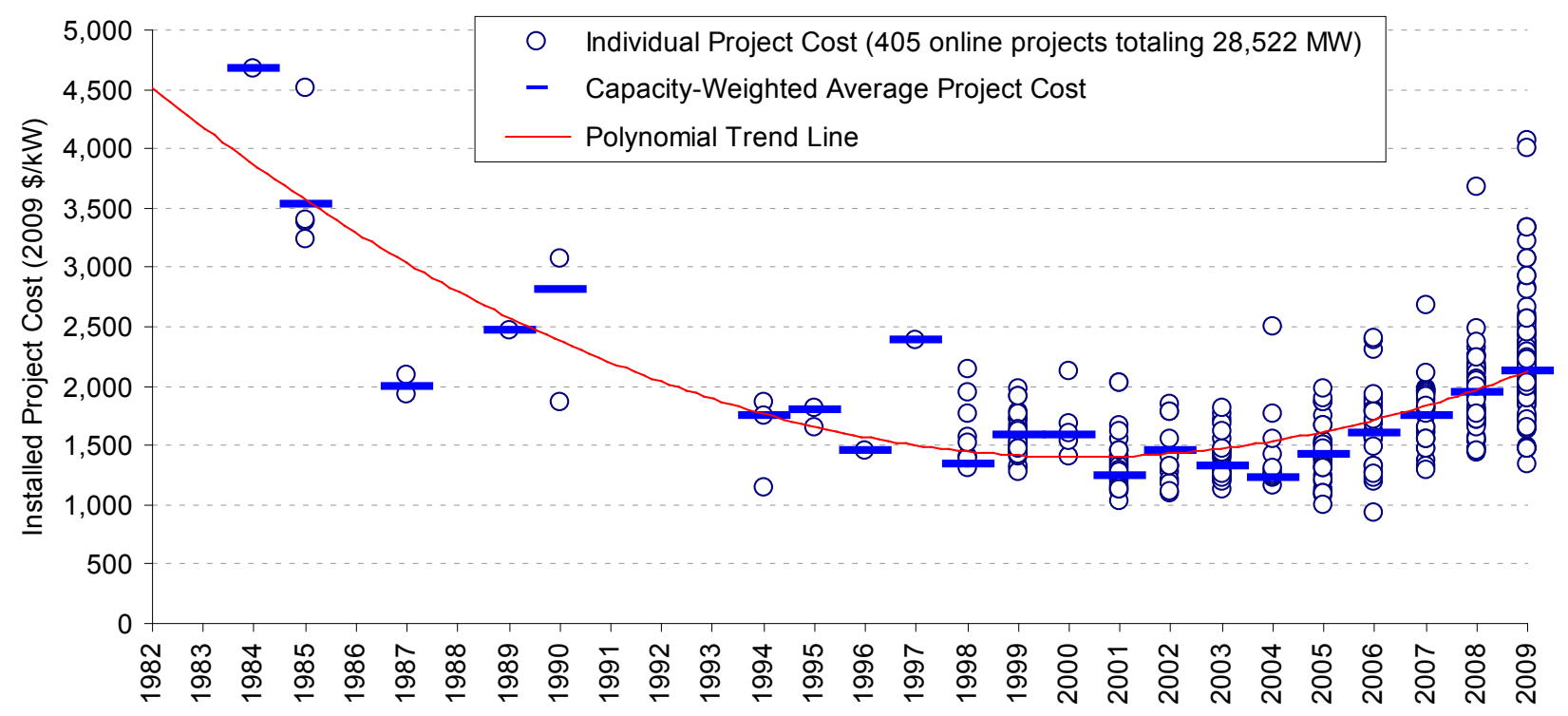

Source: Berkeley Lab (some data points suppressed to protect confidentiality)

\section{Figure 27. Installed Wind Power Project Costs Over Time}

\footnotetext{
${ }^{45}$ Limited sample size early on - particularly in the 1980 s - makes it difficult to pin down this number with a high degree of confidence.

${ }^{46}$ Learning curves have been used extensively to understand past cost trends and to forecast future cost reductions for a variety of energy technologies, including wind energy. Learning curves start with the premise that increases in the cumulative production or installation of a given technology leads to a reduction in its costs. The principal parameter calculated by learning curve studies is the learning rate: for every doubling of cumulative production/installation, the learning rate specifies the associated percentage reduction in costs. Based on the installed cost data presented in Figure 27 and global cumulative wind power installations, learning rates can be calculated as follows: $9.4 \%$ (using data from 1982 through 2009) or 14.4\% (using data only during the period of cost reduction, 1982-2004).

${ }^{47}$ It is important to recognize that wind power projects were not alone in seeing upward pressure on project costs other types of power plants experienced similar increases in capital costs. For example, the IHS CERA Power Capital Cost Index of coal, gas, and wind power plants shows a 74\% capital cost increase from 2000 to the end of 2009 (IHS CERA 2009).

${ }^{48}$ For example, data compiled by Berkeley Lab show an estimated weighted-average cost for a sample of more than $4,300 \mathrm{MW}$ of projects likely to be built in 2010 of $\$ 2,230 / \mathrm{kW}$, or $\$ 110 / \mathrm{kW}$ higher than for the sample of projects completed in 2009.
} 
Installed project costs exhibit economies of scale, at least at the low end of the project size range. Figure 28 shows that - among the sample of projects installed in 2007, 2008, or 2009 - there is a significant drop in per-kW average installed project costs when moving from projects of $5 \mathrm{MW}$ or less to projects in the 5 to $20 \mathrm{MW}$ range. As project size increases beyond $20 \mathrm{MW}$, these data do not show continued economies of scale; the reason for this latter trend is unclear.

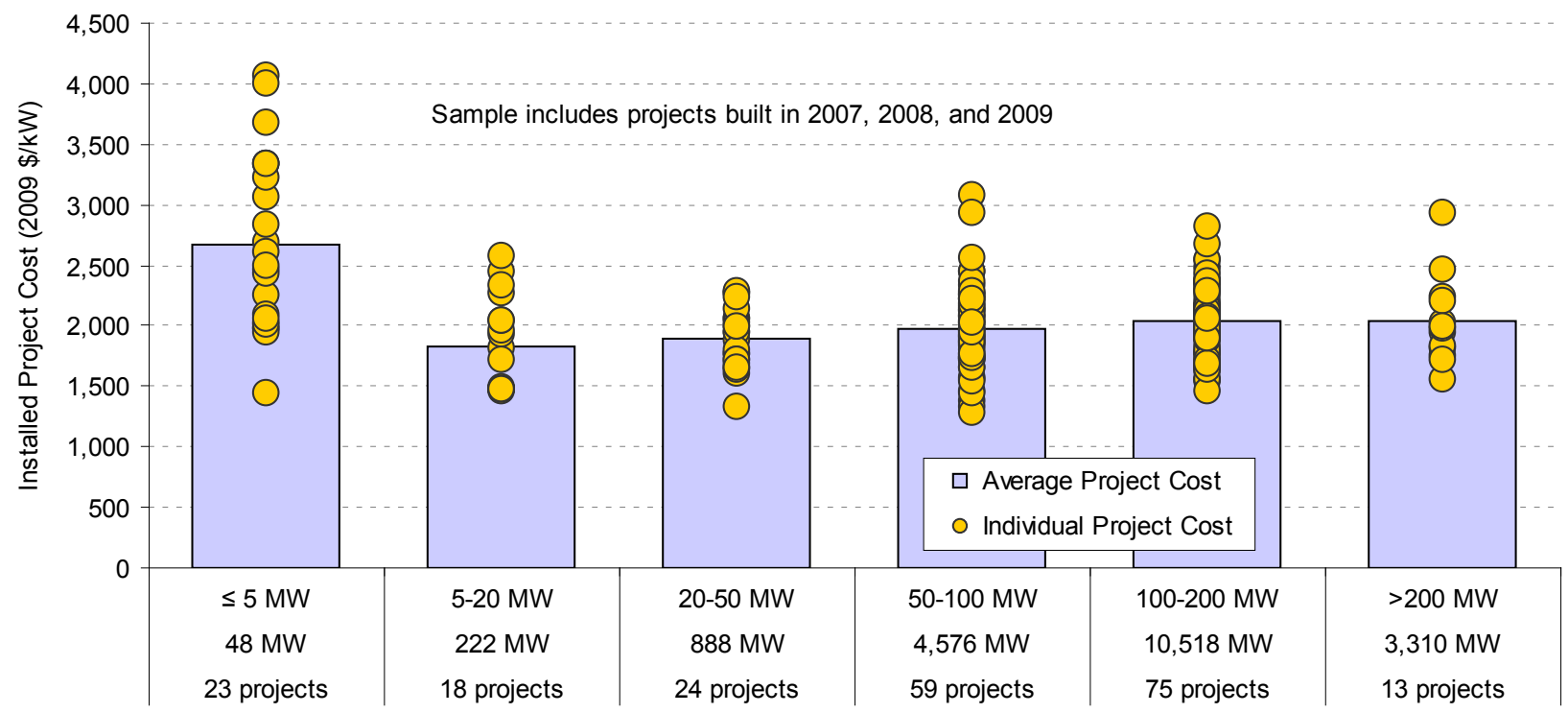

Source: Berkeley Lab

\section{Figure 28. Installed Wind Power Project Costs by Project Size: 2007-2009 Projects}

Regional differences in average project costs are also apparent, and may occur due to variations in development costs, transportation costs, siting and permitting requirements and timeframes, and other balance-of-plant and construction expenditures. Considering only projects in the sample that were installed in 2007, 2008, and 2009, Figure 29 shows that the capacity-weighted average cost equaled $\$ 2,000 / \mathrm{kW}$ nationwide over this period. Texas was the lowest-cost region, while California and New England were the highest-cost regions; all other regions came in close to the nationwide average. ${ }^{49}$

\footnotetext{
${ }^{49}$ Graphical presentation of the data in this way should be viewed with some caution, as numerous factors influence project costs (e.g., whether projects are repowered vs. "greenfield" development, etc.). Actual cost differences among some regions may therefore be more (or less) significant than they appear in Figure 29.
} 


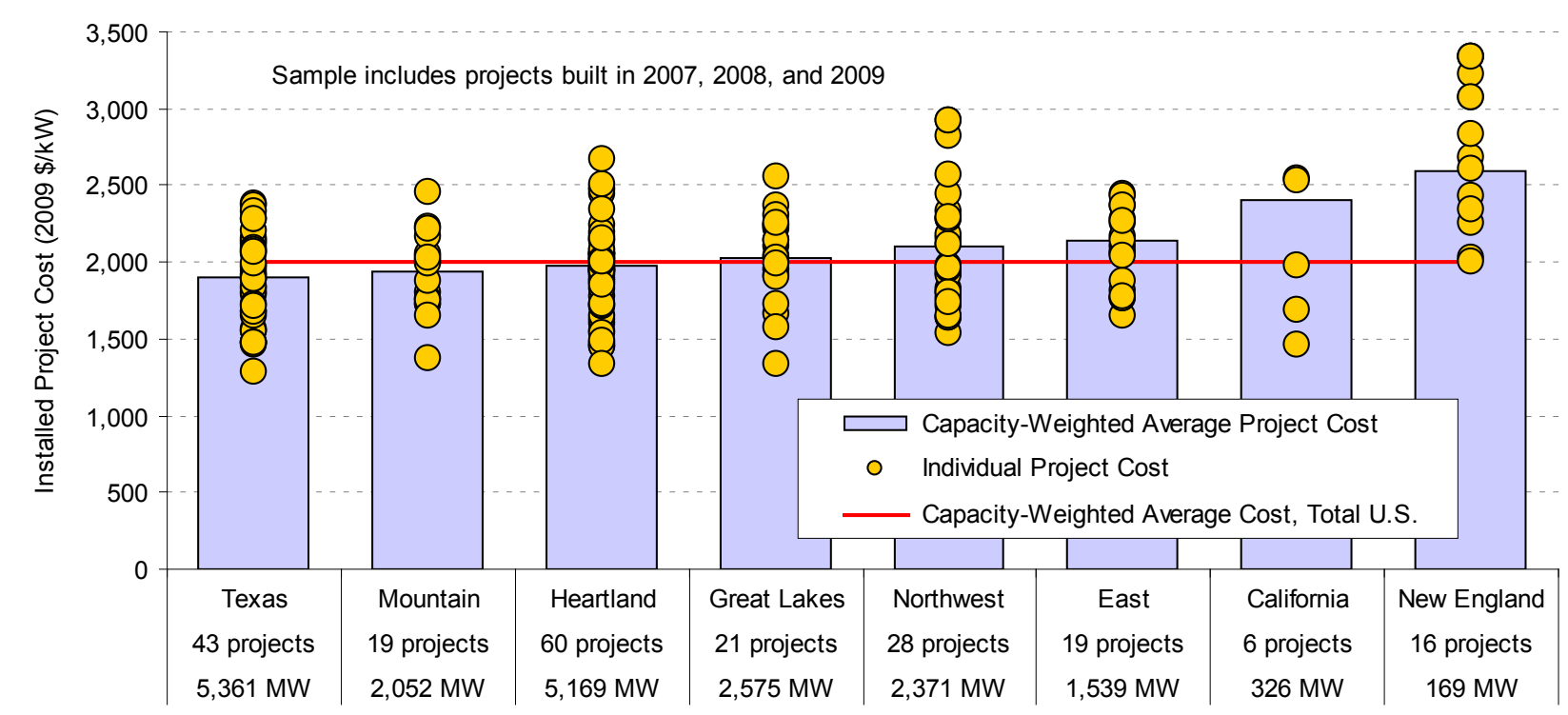

Source: Berkeley Lab

Figure 29. Installed Wind Power Project Costs by Region: 2007-2009 Projects

\section{Wind Turbine Prices Have Begun to Show Signs of Easing, but Remain High By Historical Standards}

Increases in wind power prices and overall installed project costs mirror increases in the cost of wind turbines over the last several years. Berkeley Lab has gathered data on 69 U.S. wind turbine transactions totaling 22,920 MW, including eight transactions summing to $1,674 \mathrm{MW}$ announced in 2009. Figure 30 depicts these reported wind turbine transaction prices.

Sources of transaction price data vary, but most derive from press releases and news reports. Wind turbine transactions differ in the services offered (e.g., whether towers and installation are provided, the length of the service agreement, etc.) and on the timing of future turbine delivery, driving some of the observed intra-year variability in transaction prices. Nonetheless, most of the transactions included in the Berkeley Lab dataset likely include turbines, towers, erection, and limited warranty and service agreements. ${ }^{50}$

Since hitting a low point of roughly $\$ 700 / \mathrm{kW}$ in the 2000-2002 timeframe, average wind turbine prices have increased by approximately $\$ 800 / \mathrm{kW}(>100 \%)$ through 2009 . The trend of increasing turbine prices also suggests that most of the rise in installed project costs reported earlier (\$810/kW from 2001-04 through 2009) has come from turbine price increases. Increases in turbine prices over this period have been caused by several factors, including a decline in the value of the U.S. dollar relative to the Euro, increased materials and energy input prices (e.g., steel and oil), a general move by manufacturers to improve their profitability, shortages in certain turbine components, an up-scaling of turbine size (and hub height), and improved sophistication of turbine design (e.g., improved grid interactions).

\footnotetext{
${ }^{50}$ Because of data limitations, the precise content of many of the individual transactions is not known.
} 
Figure 30 also suggests that larger turbine orders may have generally yielded somewhat lower pricing than smaller orders at any given point in time. This is reflected in the fact that the majority of the largest turbine orders shown in Figure 30 are located below the polynomial trend line, while the majority of the smallest orders are located above that line.

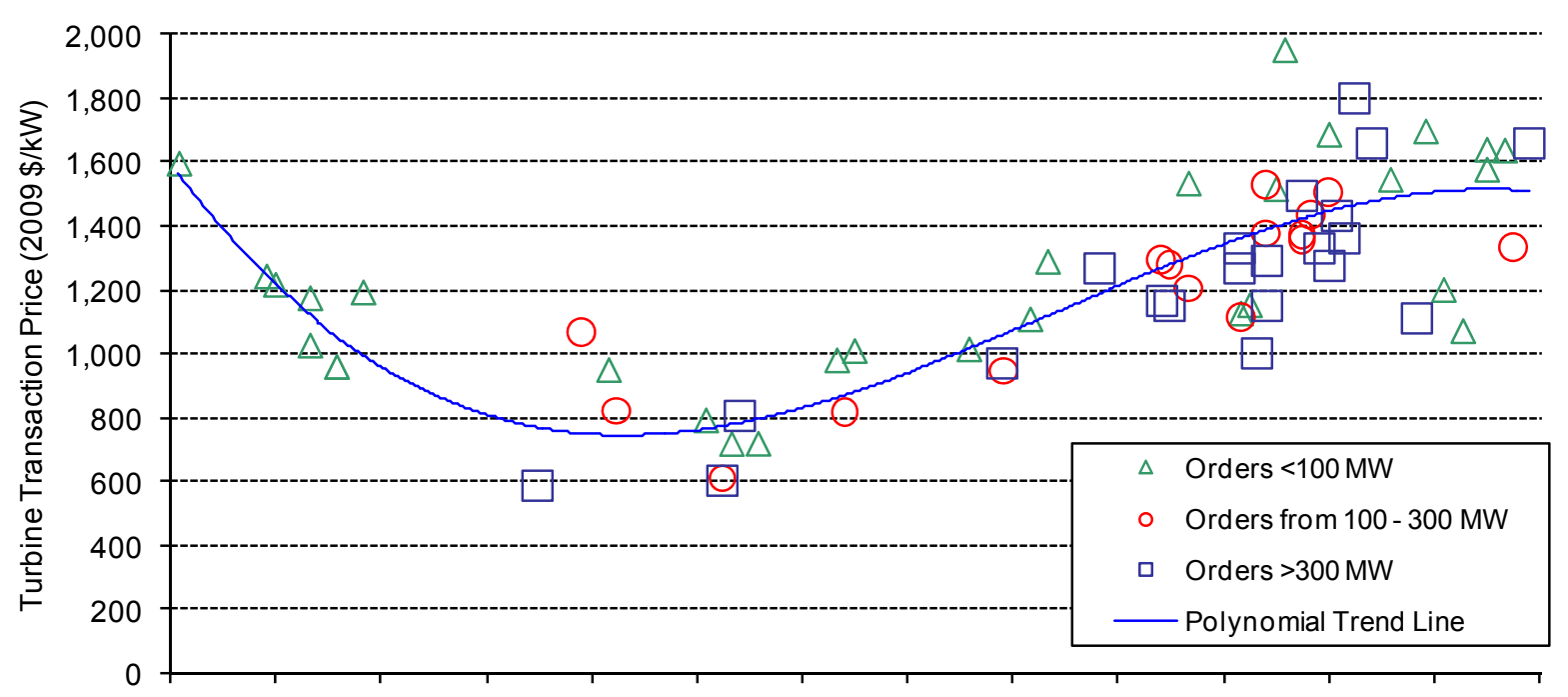

Jan-97 Jan-98 Jan-99 Jan-00 Jan-01 Jan-02 Jan-03 Jan-04 Jan-05 Jan-06 Jan-07 Jan-08 Jan-09 Jan-10

Announcement Date

Source: Berkeley Lab

\section{Figure 30. Reported U.S. Wind Turbine Transaction Prices Over Time}

Though turbine price increases have been the rule for a number of years, evidence is beginning to emerge that those days have ended, at least temporarily. As reflected by the small number of recent data points on turbine transactions shown in Figure 30, visibility of wind turbine transaction prices has declined as the financial crisis has taken its toll and developers sit on turbine supply frame agreements that have exceeded near-term project development plans. Energy and commodity prices have dropped since mid-2008, however, and the supply-demand balance for turbines has resulted in a turn towards a buyer's market (Bloomberg New Energy Finance 2010a; BTM 2010). As a result, UBS (2010) estimates a 13\% decline in average turbine sales prices in 2009, while Bloomberg New Energy Finance (2010a) estimates that turbines delivered in the second half of 2010 are priced at a 15\% discount relative to turbines delivered in the second half of 2008. More favorable terms are also on offer for turbine purchasers, including lengthier servicing agreements. These price reductions and improved terms can be expected, over time, to exert downward pressure on total project costs and wind power prices.

\section{Wind Power Project Performance Has Generally Improved Over Time, but Has Leveled Off in Recent Years}

Though turbine and installed project cost increases have driven wind power prices higher over the past several years, improvements in wind power project performance have mitigated these 
impacts to some degree. In particular, capacity factors have generally increased for projects installed more recently, driven by some combination of higher hub heights, larger rotor diameters, and other technological advancements. At the same time, these performance improvements appear to have leveled off in the most recent time period.

This section presents excerpts from a Berkeley Lab compilation of project-level capacity-factor data. The full data sample consists of 260 wind power projects built between 1983 and 2008, and totaling $22,366 \mathrm{MW}$ ( $89 \%$ of nationwide installed wind power capacity at the end of 2008). ${ }^{51}$

Focusing on a progressively larger cumulative sample of projects in each calendar year, ${ }^{52}$ Figure 31 demonstrates that average sample-wide wind power project capacity factors have, in general, gradually increased over time, from just over 24\% in 1999 (for projects installed through 1998) to a high of nearly $34 \%$ in 2008 (for projects installed through 2007), before dropping to $30 \%$ in 2009 (for projects installed through 2008).

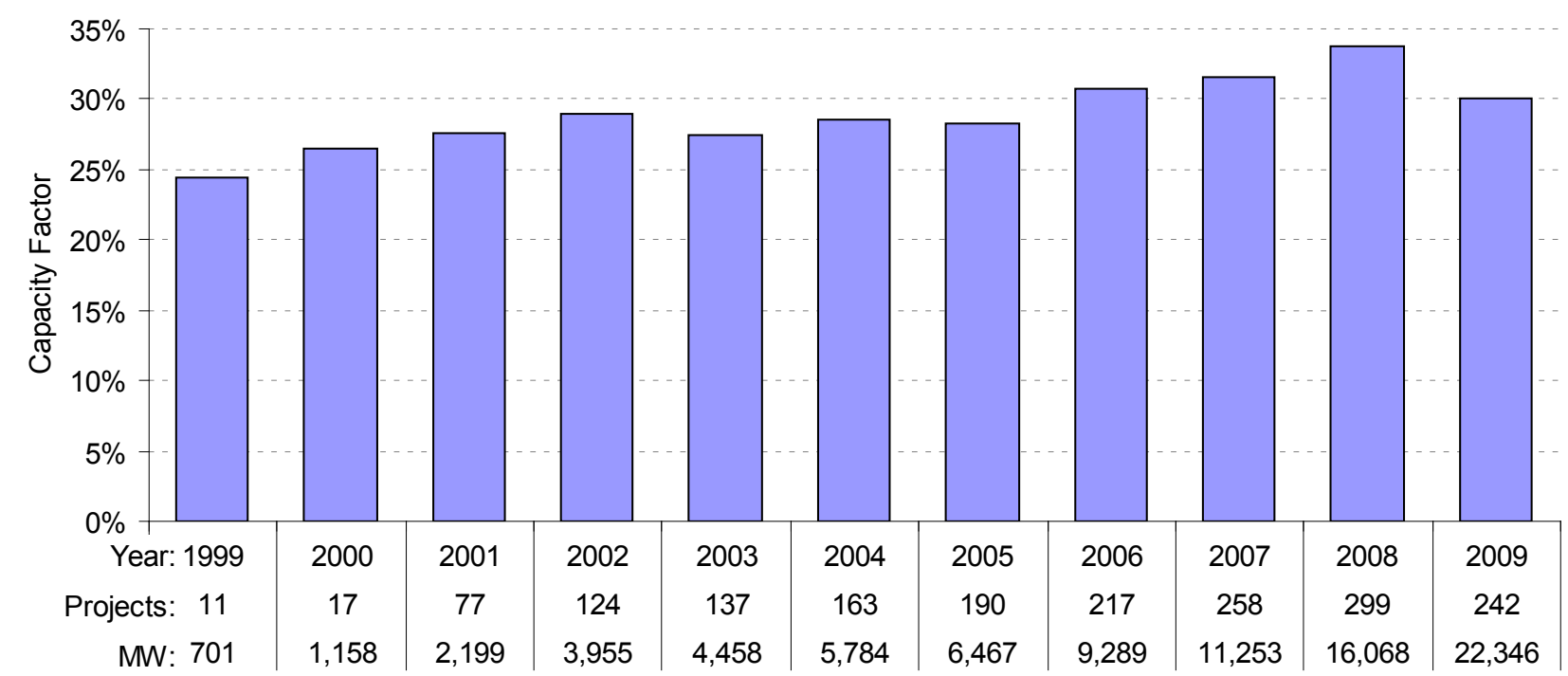

Source: Berkeley Lab

Figure 31. Average Cumulative Sample-Wide Capacity Factor by Calendar Year

The general trend of increasing capacity factors shown in Figure 31 may be due to a combination of factors, including - most prominently - the increasing hub heights and rotor diameters of more recently completed projects (documented in an earlier section) that also increase fleet-wide average turbine size over time. Turbines with higher hub heights and with larger rotor diameters (relative to nameplate capacity) will tend to have higher average capacity factors.

\footnotetext{
${ }^{51}$ Though some performance data for wind power projects installed in 2009 are available, those data do not span an entire year of operations. As such, for the purpose of this section, the focus is on projects with commercial operation dates in 2008 and earlier.

${ }^{52}$ There are fewer individual projects - though more capacity - in the cumulative sample for 2009 than there were in 2008. This is due to the sampling method used by the EIA, which focuses on a subset of larger projects throughout the year, before eventually capturing the entire sample some months after the year has ended. As a result, it might be late 2010 before the EIA reports 2009 performance data for all of the wind power projects that it tracks, and in the mean time, this report is left with a smaller sample consisting mostly of the larger projects in each state.
} 
The year-to-year variation in average capacity factors shown in Figure 31 - and especially the large drop in average capacity factors in 2009 - is also caused by changes in the quality of the wind resource from year to year and by wind power curtailment.

- Wind Resource Variation: In part as a result of El Niño, the year 2009, for example, was considered to be a generally poor wind year throughout much of the United States, with average wind speeds below their long-term average over much of the country (e.g., 3Tier 2010). The year 2008, meanwhile, was generally considered to be a good wind year. As a result, the large drop in average capacity factors between 2008 and 2009 is, in part, a reflection of natural yearly variations in national average wind resource conditions.

- Wind Power Curtailment: Increasing amounts of wind power curtailment in recent years also significantly reduced sample-wide average capacity factors in 2009. Curtailment of project output due primarily to transmission inadequacy (and, as a consequence, low wholesale electricity prices) is a growing problem, primarily in Texas, but also in other markets. Due to transmission inadequacy, wind power projects in West Texas (which represent a growing fraction of U.S. installations), for example, have been forced by grid operators to reduce their output (or have voluntarily chosen to do so in response to negative price signals in the wholesale electricity market). Figure 32 shows that roughly $17 \%$ of potential wind energy generation within ERCOT was curtailed in 2009, compared to $8 \%$ in 2008 and just 1\% in 2007 (ERCOT 2010). Curtailment was also experienced, to a much lesser degree, in other regions. In MISO, for example, roughly $1 \%$ of potential wind energy output in 2009 was curtailed (MISO 2010). As shown in Figure 31, the national sample-wide average capacity factor in 2009 with curtailment was $30 \%$. This sample-wide average capacity factor would have reached $32 \%$ if not for the curtailment experienced in ERCOT and MISO (and slightly higher were one to account for curtailment in other regions ${ }^{53}$ ).

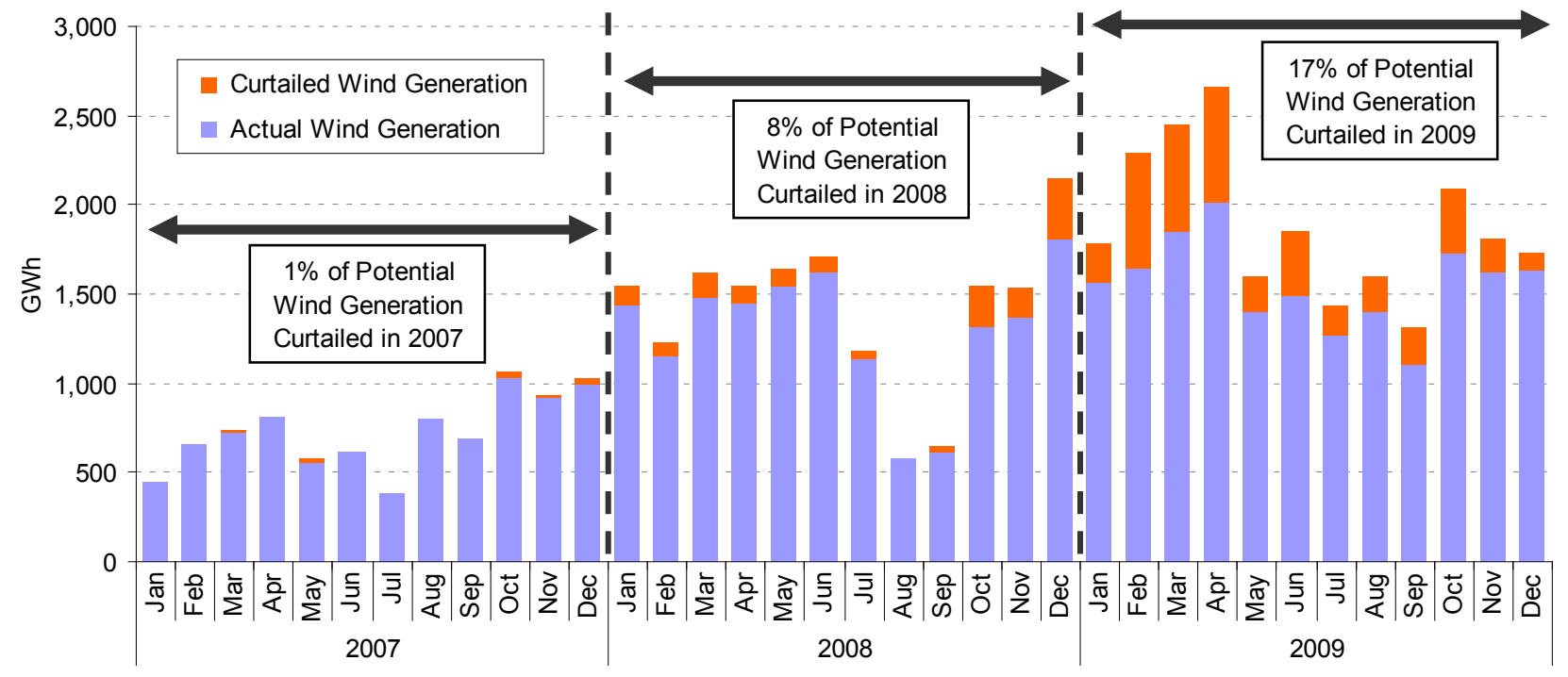

Source: ERCOT (2010)

Figure 32. History of Wind Energy Curtailment Within ERCOT: 2007-2009

\footnotetext{
${ }^{53}$ Data on curtailment in other regions were not available, but are expected to be relatively modest for 2009 .
} 
Figure 33 (as well as Figure 34 and Table 8) presents capacity factor data in a different way, by focusing just on capacity factors in the year 2009, rather than in each calendar year. ${ }^{54}$

Specifically, Figure 33 shows individual project as well as capacity-weighted average 2009 capacity factors broken out by each project's vintage (i.e., commercial operation date). The capacity-weighted average 2009 capacity factors in the Berkeley Lab sample increase from 21\% for wind power projects installed before 1998 to roughly $26 \%-27 \%$ for projects installed from $1998-2001,31 \%$ for projects installed from 2002-2003, and 34\% for projects installed in 20042005. Once again, higher hub heights and larger rotor diameters (particularly relative to turbine nameplate capacity) are likely to be largely responsible for these increases in capacity factors.

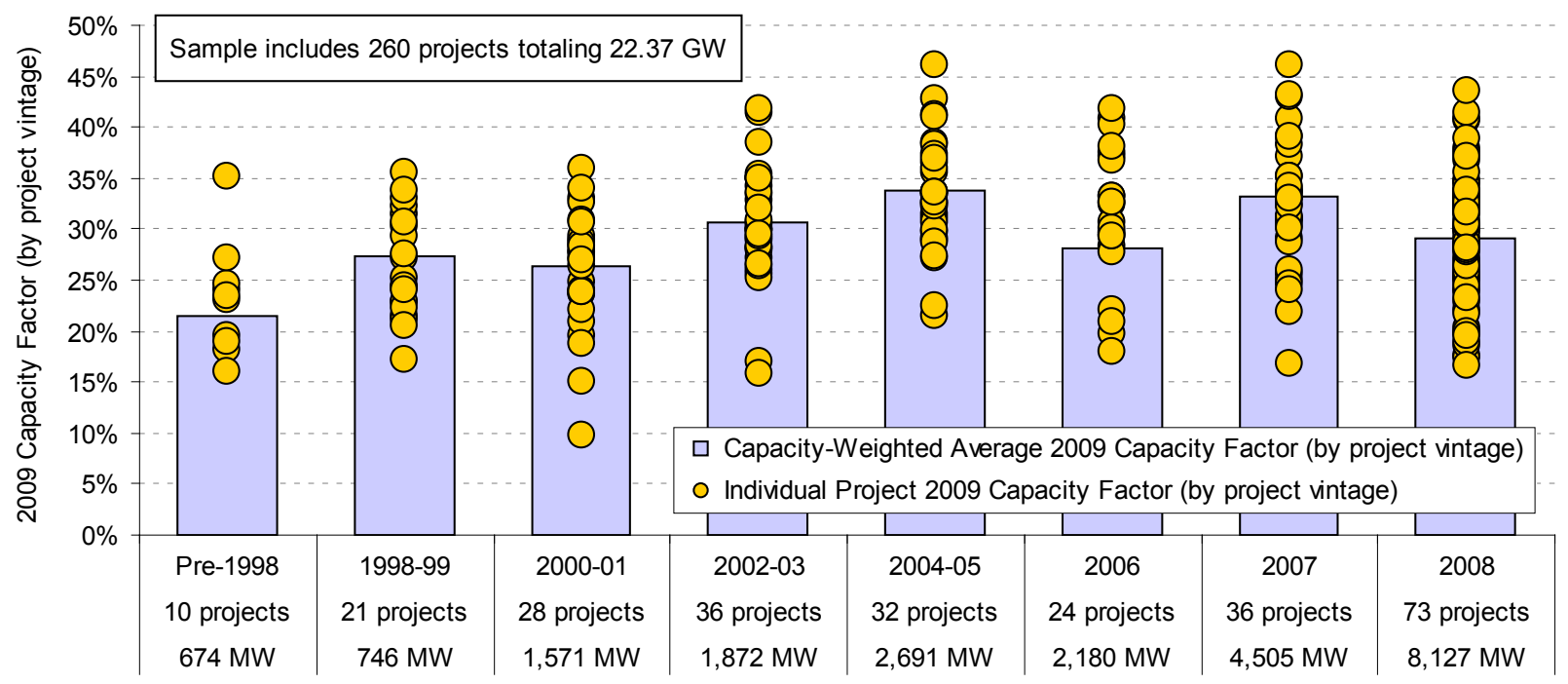

Source: Berkeley Lab

\section{Figure 33. 2009 Project Capacity Factors by Commercial Operation Date}

Projects installed since 2005, however, have in general bucked this trend of rising capacity factors among newer projects: the capacity-weighted average 2009 capacity factors for projects built in 2006, 2007, and 2008 were $28 \%, 33 \%$, and $29 \%$, respectively. Though further analysis would be needed to fully assess the reasons for this leveling of capacity factors, potential explanations include:

- Project Siting: Developers may be reacting to increasing transmission constraints (or even just regionally differentiated wholesale electricity prices, or siting constraints) by focusing on those projects in their pipeline that may not be located in the best wind resource areas, but that do have ready access to unconstrained transmission (or higher-priced markets or readily available sites without long permitting times).

\footnotetext{
${ }^{54}$ Although focusing just on 2009 tends to limit the effects of inter-annual fluctuations in the nationwide wind resource (which do impact the year to year results in Figure 31), it also means that the absolute capacity factors shown in Figure 33 may not be representative if 2009 was not a representative year in terms of the strength of the wind resource. Note also that by including only 2009 capacity factors, variations in the quality of the wind resource year in 2009 across regions could skew the regional results presented in Figure 34 and Table 8.
} 
- Technology Change: Though increases in average turbine hub height and rotor diameter have been substantial, those increases have moderated in recent years (as discussed in an earlier section), yielding a weaker technical push towards higher capacity factors.

- Turbine Reliability: Some turbine manufacturers experienced blade and gearbox problems among their fleet of turbines installed in 2007 and 2008. Additionally, for the many projects completed in late 2008, the initial break-in period during which operational kinks are worked out may have extended well into 2009, negatively impacting 2009 capacity factors.

Trends in fleet-wide average capacity factors aside, the project-level spread shown in Figure 33 is enormous, with 2009 capacity factors ranging from $16.6 \%$ to $43.5 \%$ among projects built in the same year, 2008. Some of this spread is attributable to regional variations in wind resource quality. Figure 34 shows the regional variation in 2009 capacity factors, based on a sub-sample of wind power projects built from 2004 through 2008 (i.e., a period of relative stability in capacity factors, as shown in Figure 33). For this sample of projects, weighted-average capacity factors are the highest in Hawaii (above 40\% on average) and the Mountain region (around 35\% on average), and lowest in the East (below 30\% on average) and in Texas (around 26\% on average). The relatively low 2009 average capacity factor in Texas is largely caused by curtailment within ERCOT (see Figure 32): the ERCOT-wide 2009 capacity factor with curtailment of $25.8 \%$ would have been $31.1 \%$ were there no curtailment, an absolute difference of $5.2 \%$. All other regions feature weighted-average capacity factors in 2009 that are in the 30$35 \%$ range, which is similar to the national average among the overall 2004-2008 project sample. Given the small sample size in some regions, however, as well as the possibility that certain regions may have experienced a particularly good or bad wind resource year in 2009 or different levels of wind energy curtailment, care should be taken in extrapolating these results.

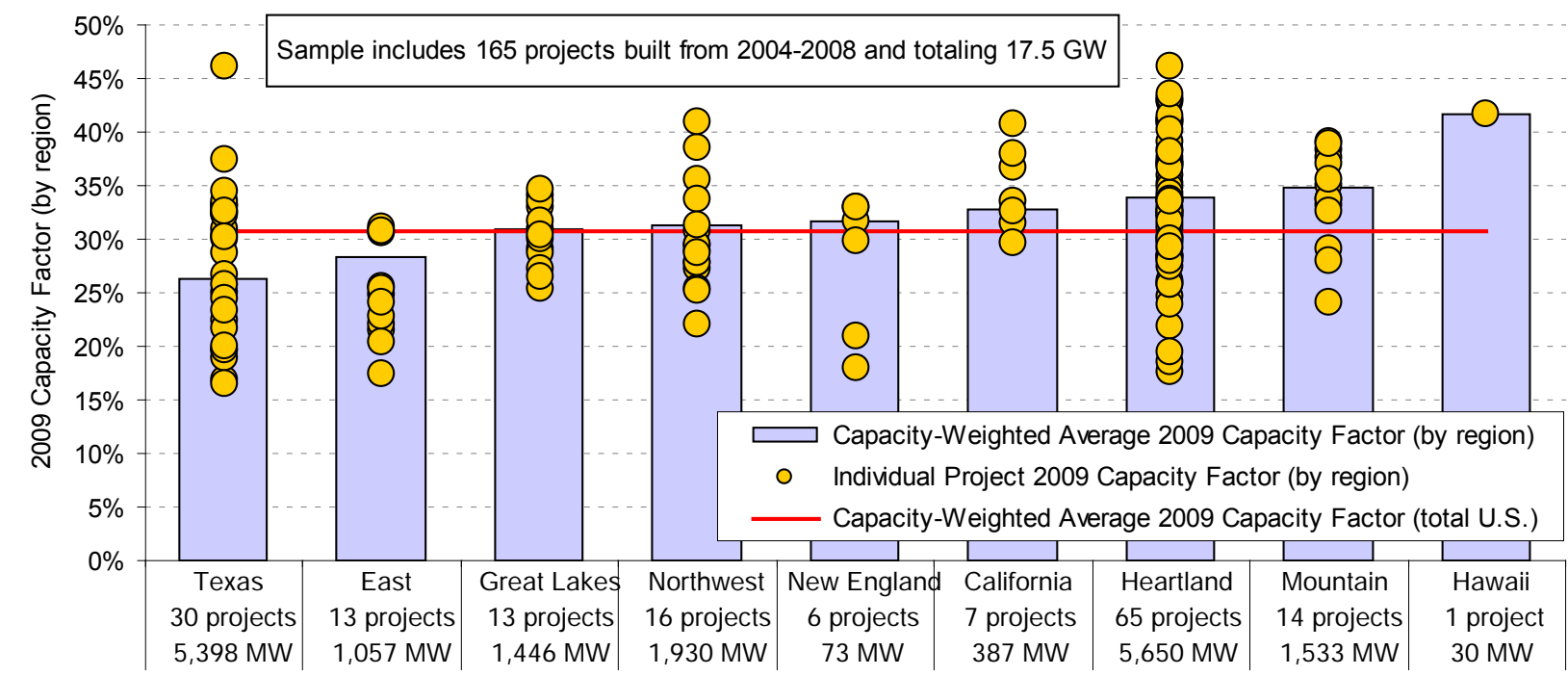

Source: Berkeley Lab

Figure 34. 2009 Project Capacity Factors by Region: 2004-2008 Projects Only 
Though limited sample size is again a problem for many regions, Table 8 illustrates trends in 2009 capacity factors for projects with different commercial operation dates, by region.

Table 8. Capacity-Weighted Average 2009 Capacity Factors by Region and COD

\begin{tabular}{|c|c|c|c|c|c|c|c|c|c|c|c|c|c|c|c|c|c|c|}
\hline $\begin{array}{c}\text { Capacity } \\
\text { Factor }\end{array}$ & \multicolumn{2}{|c|}{ Texas } & \multicolumn{2}{|c|}{ East } & \multicolumn{2}{|c|}{$\begin{array}{l}\text { Great } \\
\text { Lakes }\end{array}$} & \multicolumn{2}{|c|}{ Northwest } & \multicolumn{2}{|c|}{$\begin{array}{c}\text { New } \\
\text { England }\end{array}$} & \multicolumn{2}{|c|}{ California } & \multicolumn{2}{|c|}{ Heartland } & \multicolumn{2}{|c|}{ Mountain } & \multicolumn{2}{|c|}{ Hawaii } \\
\hline Pre-1998 & \multicolumn{2}{|r|}{-} & \multicolumn{2}{|c|}{-} & \multicolumn{2}{|r|}{-} & \multicolumn{2}{|c|}{-} & \multicolumn{2}{|c|}{$24.1 \%$} & \multicolumn{2}{|c|}{$21.4 \%$} & \multicolumn{2}{|c|}{$23.4 \%$} & \multicolumn{2}{|c|}{-} & \multicolumn{2}{|c|}{-} \\
\hline 1998-99 & \multicolumn{2}{|r|}{-} & \multicolumn{2}{|c|}{-} & \multicolumn{2}{|c|}{$19.0 \%$} & \multicolumn{2}{|c|}{$31.4 \%$} & \multicolumn{2}{|c|}{-} & \multicolumn{2}{|c|}{$30.7 \%$} & \multicolumn{2}{|c|}{$25.8 \%$} & \multicolumn{2}{|c|}{$32.2 \%$} & \multicolumn{2}{|c|}{-} \\
\hline $2000-01$ & \multicolumn{2}{|c|}{$25.8 \%$} & \multicolumn{2}{|c|}{$22.7 \%$} & \multicolumn{2}{|c|}{$20.9 \%$} & & $.6 \%$ & & - & & $.7 \%$ & 32. & $3 \%$ & & $.9 \%$ & & - \\
\hline $2002-03$ & & $3 \%$ & & $.9 \%$ & & $.1 \%$ & & $.9 \%$ & & - & & $.4 \%$ & 33 & $3 \%$ & & $.7 \%$ & & - \\
\hline 2004-05 & & $.2 \%$ & & $.9 \%$ & & $.0 \%$ & & $.8 \%$ & & - & & $.0 \%$ & 36 & $7 \%$ & & $.4 \%$ & & - \\
\hline 2006 & & $.6 \%$ & & $.7 \%$ & & - & & $6 \%$ & & $4 \%$ & & $.2 \%$ & 36. & $6 \%$ & & $.9 \%$ & 41. & $.7 \%$ \\
\hline 2007 & & $.2 \%$ & & $.6 \%$ & & $.6 \%$ & & $.7 \%$ & & $9 \%$ & & - & 35 & $2 \%$ & & $.4 \%$ & & - \\
\hline 2008 & & $.5 \%$ & & $.6 \%$ & & $.4 \%$ & & $.1 \%$ & & $1 \%$ & & $.9 \%$ & 32 & $2 \%$ & & $.8 \%$ & & - \\
\hline Total & & $.2 \%$ & & $.0 \%$ & & $.2 \%$ & & $.3 \%$ & & $1 \%$ & & $.4 \%$ & 33 & $2 \%$ & & $.4 \%$ & 41. & $.7 \%$ \\
\hline Sample & \# & MW & \# & MW & \# & MW & \# & MW & \# & MW & \# & MW & \# & MW & \# & MW & \# & MW \\
\hline Pre-1998 & 0 & 0 & 0 & 0 & 0 & 0 & 0 & 0 & 1 & 6 & 8 & 642 & 1 & 26 & 0 & 0 & 0 & 0 \\
\hline 1998-99 & 0 & 0 & 0 & 0 & 2 & 20 & 1 & 25 & 0 & 0 & 6 & 192 & 10 & 482 & 2 & 27 & 0 & 0 \\
\hline 2000-01 & 4 & 669 & 6 & 83 & 1 & 30 & 3 & 373 & 0 & 0 & 1 & 67 & 9 & 227 & 4 & 123 & 0 & 0 \\
\hline $2002-03$ & 1 & 160 & 3 & 161 & 1 & 50 & 2 & 105 & 0 & 0 & 4 & 287 & 22 & 600 & 3 & 510 & 0 & 0 \\
\hline 2004-05 & 4 & 461 & 2 & 349 & 1 & 54 & 5 & 434 & 0 & 0 & 3 & 130 & 15 & 1,062 & 2 & 200 & 0 & 0 \\
\hline 2006 & 2 & 860 & 1 & 26 & 0 & 0 & 4 & 538 & 2 & 1 & 2 & 188 & 10 & 387 & 2 & 150 & 1 & 30 \\
\hline 2007 & 7 & 1,135 & 4 & 169 & 5 & 679 & 4 & 654 & 2 & 44 & 0 & 0 & 10 & 1,049 & 4 & 776 & 0 & 0 \\
\hline 2008 & 17 & 2,942 & 6 & 513 & 7 & 712 & 3 & 303 & 2 & 29 & 2 & 69 & 30 & 3,152 & 6 & 407 & 0 & 0 \\
\hline Total & 35 & 6,226 & 22 & 1,300 & 17 & 1,546 & 22 & 2,433 & 7 & 79 & 26 & 1,575 & 107 & 6,985 & 23 & 2,192 & 1 & 30 \\
\hline
\end{tabular}

\section{Operations and Maintenance Costs Are Affected by the Age and Size of the Project, Among Other Factors}

Operations and maintenance (O\&M) costs are a significant component of the overall cost of wind energy, but can vary substantially among projects. Market data on actual project-level O\&M costs are not widely and readily available. Even where data are available, care must be taken in extrapolating historical O\&M costs given the dramatic changes in wind turbine technology that have occurred over the last two decades, not least of which has been the upscaling of turbine size (see Figures 14 and 15, earlier). Anecdotal evidence suggests that O\&M costs and premature component failures continue to be key challenges to the wind power industry.

Berkeley Lab has compiled O\&M cost data for 115 installed wind power projects in the United States, totaling 6,097 MW of capacity, with commercial operation dates of 1982 through 2008. These data cover facilities owned by both independent power producers and utilities, though data since 2004 are exclusively from utility-owned projects. A full time series of O\&M cost data, by year, is available for only a small number of projects; in all other cases, O\&M cost data are available for just a subset of years of project operations. Although the data sources do not all clearly define what items are included in O\&M costs, in most cases the reported values appear to include the costs of wages and materials associated with operating and maintaining the facility, as well as rent (i.e., land lease payments). Other ongoing expenses, including taxes, property 
insurance, and workers' compensation insurance, are generally not included. Given the scarcity, limited content, and varying quality of the data, the results that follow may not fully depict the industry's challenges with O\&M issues and expenditures; instead, these results should only be taken as illustrative of overall trends. Note also that the available data are presented in $\$ / \mathrm{MWh}$ terms, as if O\&M represents a variable cost; in fact, O\&M costs are in part variable and in part fixed. Although not presented here, expressing O\&M costs in units of $\$ / \mathrm{kW}$-year yields qualitatively similar results to those presented in this section.

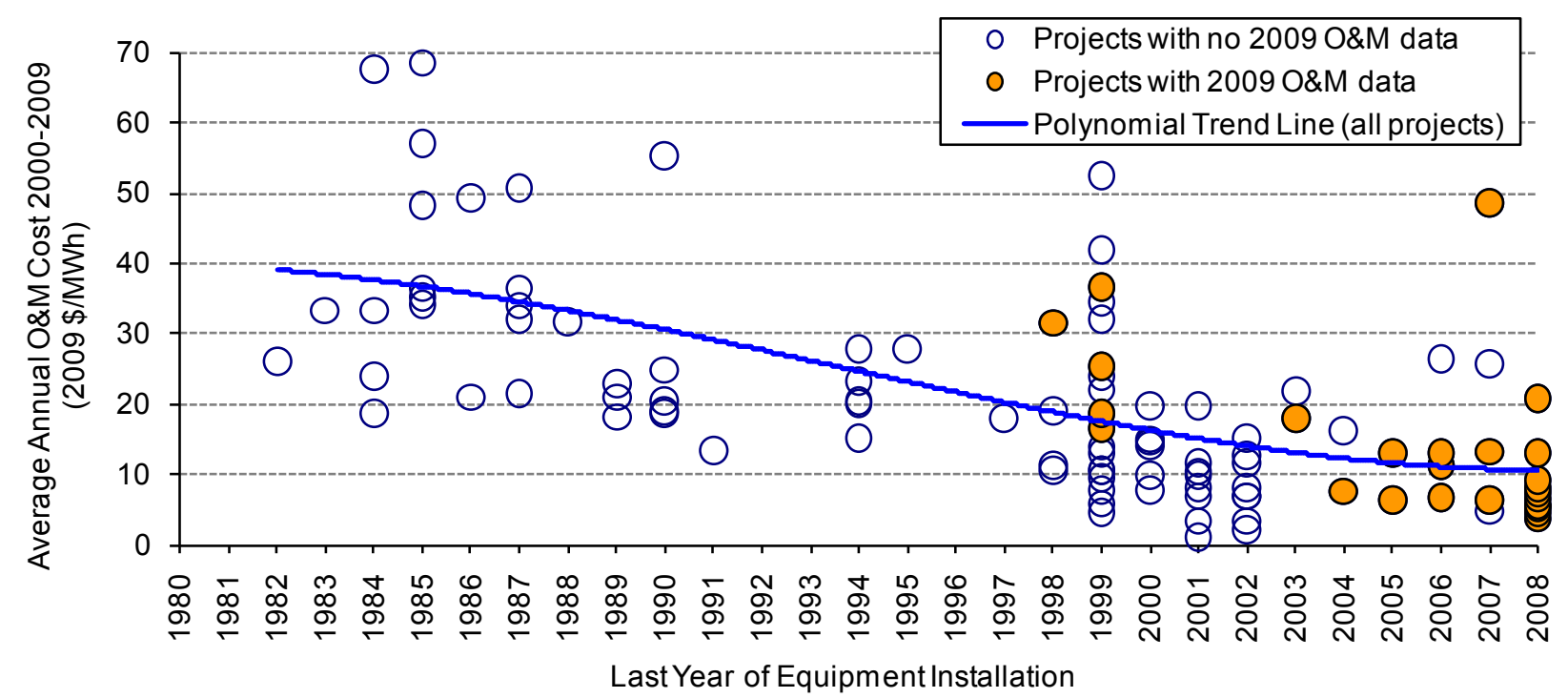

Source: Berkeley Lab; seven data points suppressed to protect confidentiality

Figure 35. Average O\&M Costs for Available Data Years from 2000-2009, by Last Year of Equipment Installation

Figure 35 shows project-level O\&M costs by year of project installation (i.e., the most recent year that original equipment was installed, or the most recent year of project repowering). Here, O\&M costs represent an average of annual project-level data available for the years 2000 through 2009. For example, for projects that reached commercial operations in 2008, only year 2009 data are available, and that is what is shown in the figure. ${ }^{55}$ Many other projects only have data for a subset of years during the 2000-09 timeframe, either because they were installed after 2000 or because a full time series is not available, so each data point in the chart may represent a different averaging period over 2000-09. The chart highlights the 27 projects, totaling 2,450 MW, for which 2009 O\&M cost data were available.

The data exhibit considerable spread, demonstrating that O\&M costs are far from uniform across projects. However, Figure 35 suggests that projects installed more recently have, on average, incurred lower O\&M costs. Specifically, capacity-weighted average 2000-09 O\&M costs for projects in the sample constructed in the 1980s equal $\$ 32 / \mathrm{MWh}$, dropping to $\$ 22 / \mathrm{MWh}$ for projects installed in the 1990 s, and to $\$ 9 / \mathrm{MWh}$ for projects installed in the 2000s. This drop in

\footnotetext{
${ }^{55}$ Projects installed in 2009 are not shown because only data from the first full year of project operations (and afterwards) are used, which in the case of projects installed in 2009 would be year 2010 (for which data are not yet available).
} 
O\&M costs may be due to a combination of at least two factors: (1) O\&M costs generally increase as turbines age, component failures become more common, and manufacturer warranties expire ${ }^{56}$; and (2) projects installed more recently, with larger turbines and more sophisticated designs, may experience lower overall O\&M costs on a per-MWh basis.

To help illustrate the possible influence of these two factors, Figure 36 shows annual O\&M costs over time, based on the number of years since the last year of equipment installation. Annual data for projects of similar vintages are averaged together, and data for projects under $5 \mathrm{MW}$ in size are excluded (to help control for the confounding influence of economies of scale). Note that, for each group, the number of projects used to compute the average annual values shown in the figure is limited, and varies substantially (from 4 to 18 data points per project-year for projects installed prior to 2000; from 6 to 15 data points per project-year for projects installed in 2000 through 2002; from 2 to 4 data points per project-year for projects installed in 2003 through 2005, and from 3 to 20 data points per project-year for projects installed in 2006 through 2008). With this limitation in mind, the figure shows that projects installed more recently have had, at least during their first two years of operation, lower O\&M costs than those installed in earlier years. $^{57}$ In addition, pre-2000 projects show an upward trend in project-level O\&M costs after the third year of project operation, though the sample size after year four is quite limited.

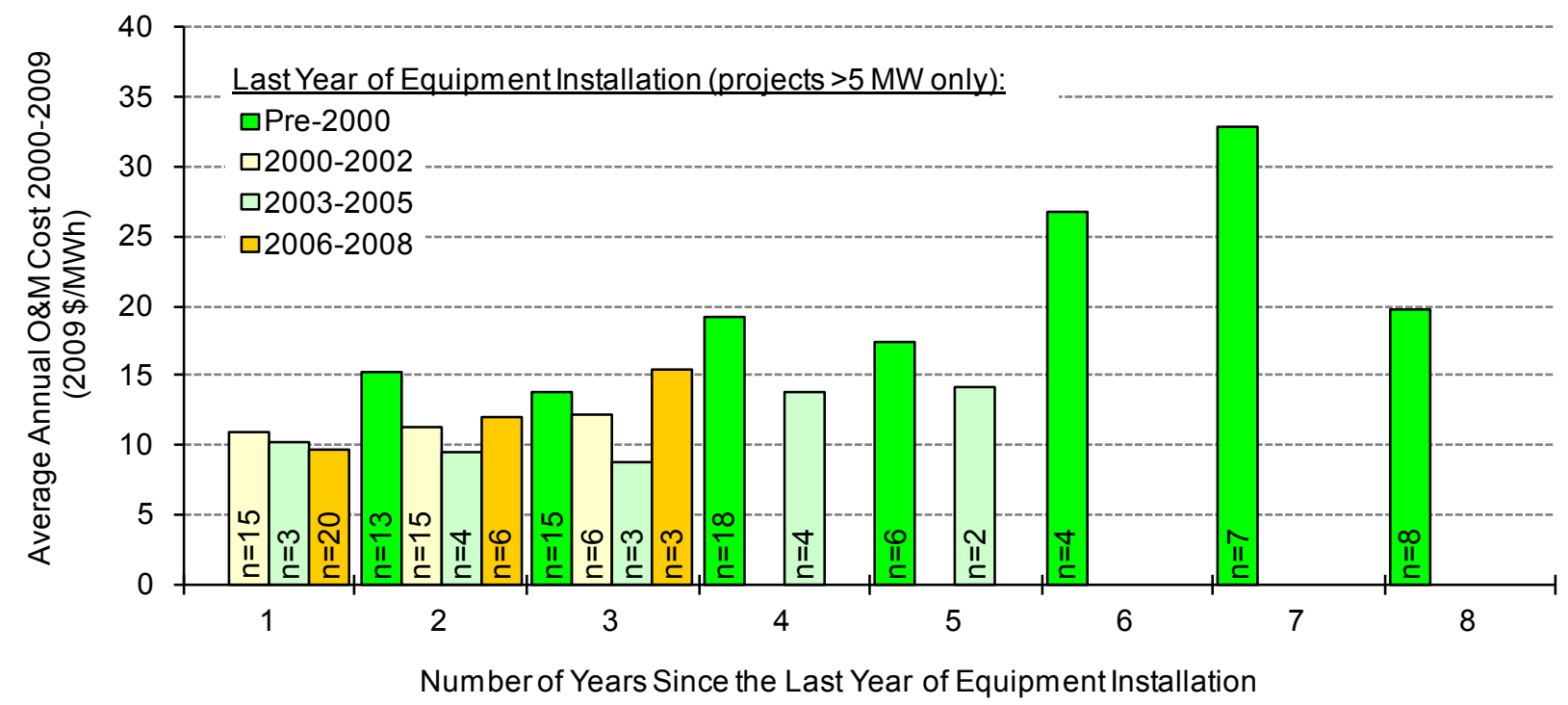

Source: Berkeley Lab; averages shown only for groups of two or more projects

Figure 36. Annual Average O\&M Costs, by Project Age and Last Year of Equipment Installation

\footnotetext{
${ }^{56}$ Many of the projects installed more-recently may still be within their turbine manufacturer warranty period, in which case the O\&M costs reported here may or may not include the costs of the turbine warranty, depending on whether the warranty is paid up-front as part of the turbine purchase, or is paid over time.

${ }^{57}$ Figure 36 shows that, among projects in their third year of commercial operation, the most recent vintage of projects (i.e., those installed between 2006 and 2008) had the highest average O\&M costs. This is the result, however, of a single project completed in 2006 with particularly high O\&M costs in its third year of operation.
} 
Another variable that may impact O\&M costs is project size. Figure 37 presents average O\&M costs for 2000 through 2009 (as in Figure 35) relative to project size. Though the sample is too small for definite conclusions, project size does appear to have some impact on average O\&M costs, with higher costs typically experienced by smaller projects.

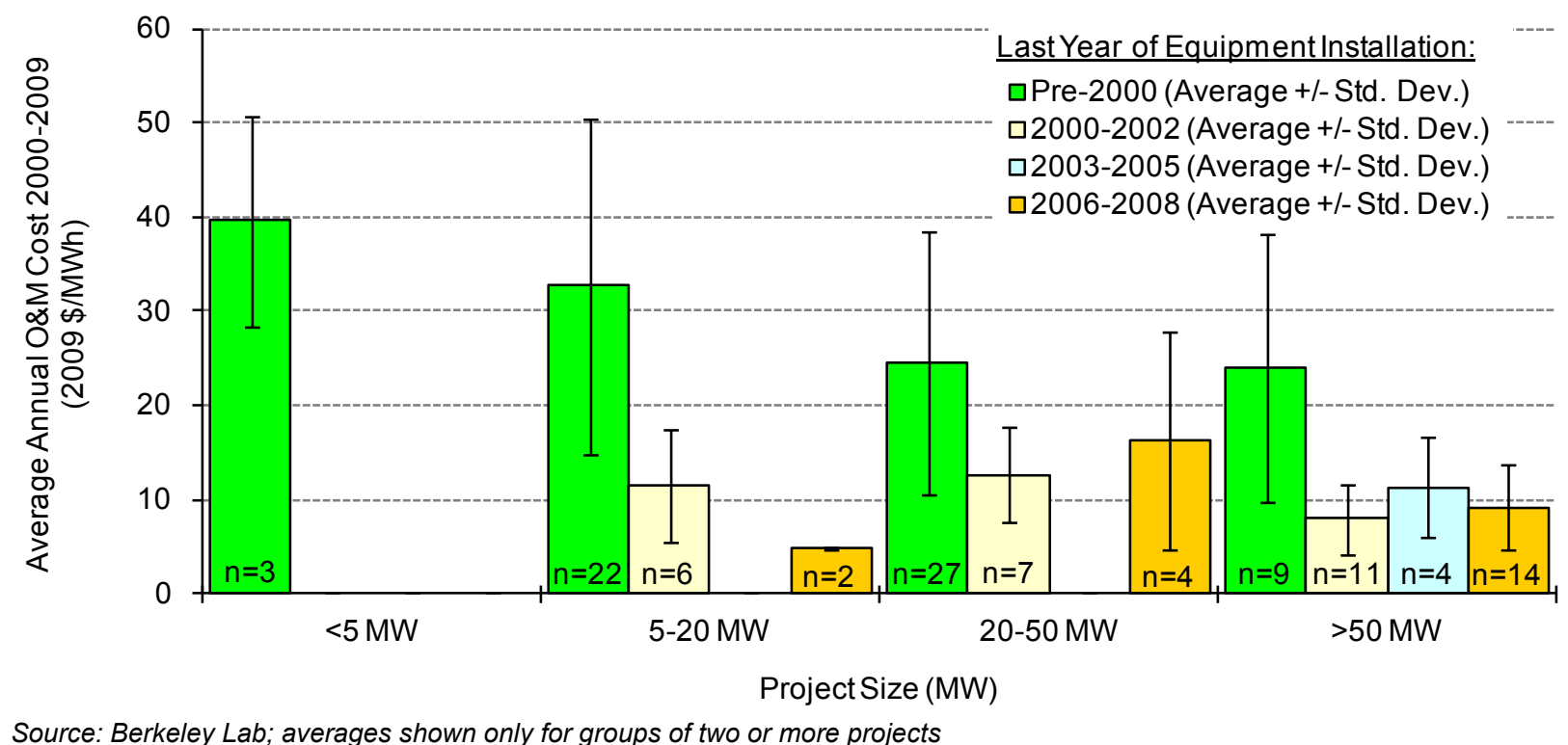

Figure 37. Average O\&M Costs for Available Data Years from 2000-2008, by Project Size 


\section{Policy and Market Drivers}

\section{The Federal Policy Landscape Is Now More Favorable to Wind Energy than at Any Other Time in the Past Decade}

A variety of policy drivers at both the federal and state levels have been important to the expansion of the wind power market in the United States At the federal level, perhaps the two most important policy incentives - at least in recent years - have been the PTC and accelerated tax depreciation. First established by the Energy Policy Act of 1992, the PTC provides a 10-year credit at a level that equaled $2.1 \notin / \mathrm{kWh}$ in 2009 (adjusted annually for inflation), and increases to $2.2 \notin / \mathrm{kWh}$ in 2010 . The historical importance of the PTC to the U.S. wind power industry is illustrated by the pronounced lulls in wind power capacity additions in the three years (2000, 2002, and 2004) in which the PTC lapsed, as well as the increased development activity often seen during the year in which the PTC is otherwise scheduled to expire (see Figure 1).

Accelerated tax depreciation, meanwhile, enables project owners to depreciate the vast majority of their investments over a five- to six-year period for tax purposes. An even-more-attractive $50 \%$ "bonus depreciation" schedule was in place during 2009, serving as an incremental driver of wind capacity additions in that year.

Although these two federal incentives will likely remain important going forward (the PTC is currently in place through 2012, having been extended as part of the Recovery Act; while accelerated depreciation has no expiration date), in 2009 the PTC in particular was overshadowed by the Section 1603 Treasury cash grant program, enacted as part of the Recovery Act in February 2009. Acknowledging the conspicuous absence of tax equity investors in the market following the financial crisis of late 2008, Section 1603 of the Recovery Act enables wind power and other qualifying projects to elect a 30\% cash grant in lieu of the PTC or ITC. Relative to the PTC, the $30 \%$ cash grant can provide a significant amount of value to wind power projects (Bolinger et al. 2010). Not surprisingly, then, the program has been heavily subscribed by wind power projects, which as of mid-July 2010 had received $88 \%$ of the more than $\$ 4.78$ billion in Section 1603 cash grants awarded since the program's implementation in late-July 2009. More than 6,400 MW - i.e., more than $64 \%$ - of all new wind power capacity installed in the United States in 2009 chose the grant (Bolinger et al. 2010). The Section 1603 program should continue to be a strong driver for at least another year - wind power projects must begin construction by the end of 2010, and be operating by the end of 2012, in order to qualify for the grant - and several proposals exist to extend the program in some form.

Two other Recovery Act programs also played a (more limited) role in the wind energy sector in 2009. First, Title IV of the Recovery Act expanded a loan guarantee program that was originally enacted as part of the Energy Policy Act of 2005. The original program, under Section 1703, is targeted at projects that manufacture or utilize innovative clean energy technologies. The first two such guarantees for projects in the wind sector were conditionally awarded in 2009 and early 2010: Nordic Windpower received a \$16 million loan guarantee to expand its two-bladed wind turbine manufacturing facility in Pocatello, Idaho, while developer First Wind received a \$117 million loan guarantee for its $30 \mathrm{MW} \mathrm{Kahuku}$ wind project (which will include battery storage) in Hawaii. The Recovery Act also created a sister loan guarantee program, called the Section 
1705 program, for projects using commercially proven technologies, but as of mid-July 2010, no wind power projects had yet been awarded Section 1705 loan guarantees.

Second, to encourage the growth of green manufacturing jobs in the United States, the Recovery Act created an advanced energy manufacturing tax credit, also known as the Section 48C credit, which provides a 30\% tax credit for investments in new clean energy manufacturing facilities.

More than 500 applications seeking in excess of $\$ 8$ billion in Section $48 \mathrm{C}$ credits were submitted by the October 2009 deadline, exceeding the $\$ 2.3$ billion program cap by more than a 3-to- 1 margin. In early January 2010, 183 manufacturing projects spread across 43 states received credit allocations totaling $\$ 2.3$ billion, with the wind energy sector capturing more than $10 \%$ of this total. Recipients are under no obligation to proceed with their projects, but in order to realize the credit, they must commission their facilities by February 2013. The Obama administration is seeking to extend the program for another year, with an additional $\$ 5$ billion (Office of the Press Secretary, 2010).

In addition to the tax benefits and Recovery Act programs discussed above, a number of other federal policies have also helped to support different segments of the wind power industry in recent years. For example, because tax-exempt entities are unable to take direct advantage of tax incentives, the Energy Policy Act of 2005 created the Clean Renewable Energy Bond (CREB) program, authorizing $\$ 800$ million of what is effectively interest-free debt (though not without certain additional transaction costs) to eligible renewable projects. ${ }^{58}$ Another $\$ 400$ million of "old CREBs" were authorized in late 2006, followed by $\$ 2.4$ billion in "new CREBs" authorized by the Extension Act of 2008 ( $\$ 800$ million) and Recovery Act of 2009 (\$1.6 billion). This old/new distinction is pertinent because "new CREBs" must follow a different set of rules largely aimed at increasing the bonds' effectiveness - than existed under the "old CREBs." Applications for the \$2.4 billion in "new CREBs" were due in early August 2009, and in late October, $\$ 2.2$ billion in CREB allocations were awarded, with more than $\$ 450$ million going to wind power projects. ${ }^{59}$

Finally, since 2003 the federal government has offered financial assistance to wind power (and other types of) projects that are located in rural areas. Specifically, Section 9006 of Title IX of The Farm Security and Rural Investment Act of 2002 established The Renewable Energy Systems and Energy Efficiency Improvements Program (the Section 9006 program). Administered by the USDA, the Section 9006 program provided grants and loan guarantees to farmers, ranchers, and rural small businesses for assistance with purchasing renewable energy systems and making energy efficiency improvements. In May 2008, the Section 9006 program was converted to the Rural Energy for America Program (the REAP) by The Food, Conservation, and Energy Act of 2008. The REAP is little changed from the Section 9006 program - i.e., the REAP still targets agricultural producers and rural small businesses (including special purpose project companies set up specifically to own wind power projects) with grants and loan guarantees to encourage the

\footnotetext{
58 Such entities have also been eligible to receive the Renewable Energy Production Incentive, which nominally offers a 10-year cash payment equal in face value to the PTC, but the need for annual appropriations and insufficient funding under those appropriations has limited the availability of these payments and therefore also the effectiveness of the program.

59 The $\$ 800$ million portion of the $\$ 2.4$ billion authorization that was reserved for rural electric cooperatives was undersubscribed by $\$ 200$ million, which is why only $\$ 2.2$ billion was allocated.
} 
installation of renewable energy systems and energy efficient upgrades. Grants are limited to the lesser of $25 \%$ of the project's cost or $\$ 500,000$, whereas loan guarantees may not exceed $\$ 25$ million (the combined amount of a grant and loan guarantee may not exceed $75 \%$ of a project's cost). In 2009, the USDA awarded more than $\$ 60$ million through the REAP program (only a portion of which went to wind), while applications for an additional $\$ 100$ million were due by June 30, 2010.

\section{State Policies Play a Significant Role in Directing the Location and Amount of Wind Power Development}

State policies continue to play a substantial role in directing the location and amount of wind power development. From 1999 through 2009, for example, 61\% of the wind power capacity built in the United States was located in states with RPS policies; in 2009, this proportion was $57 \%$. One new state (Kansas) established a mandatory RPS program in 2009, bringing the total to 29 states and Washington D.C. (see Figure 38); a number of additional states strengthened previously established RPS programs in 2009. In aggregate, existing state RPS policies would require roughly $73 \mathrm{GW}$ of new renewable capacity by 2025 , representing roughly $6 \%$ of total U.S. retail electricity sales in that year and $30 \%$ of projected load growth between 2000 and 2025.

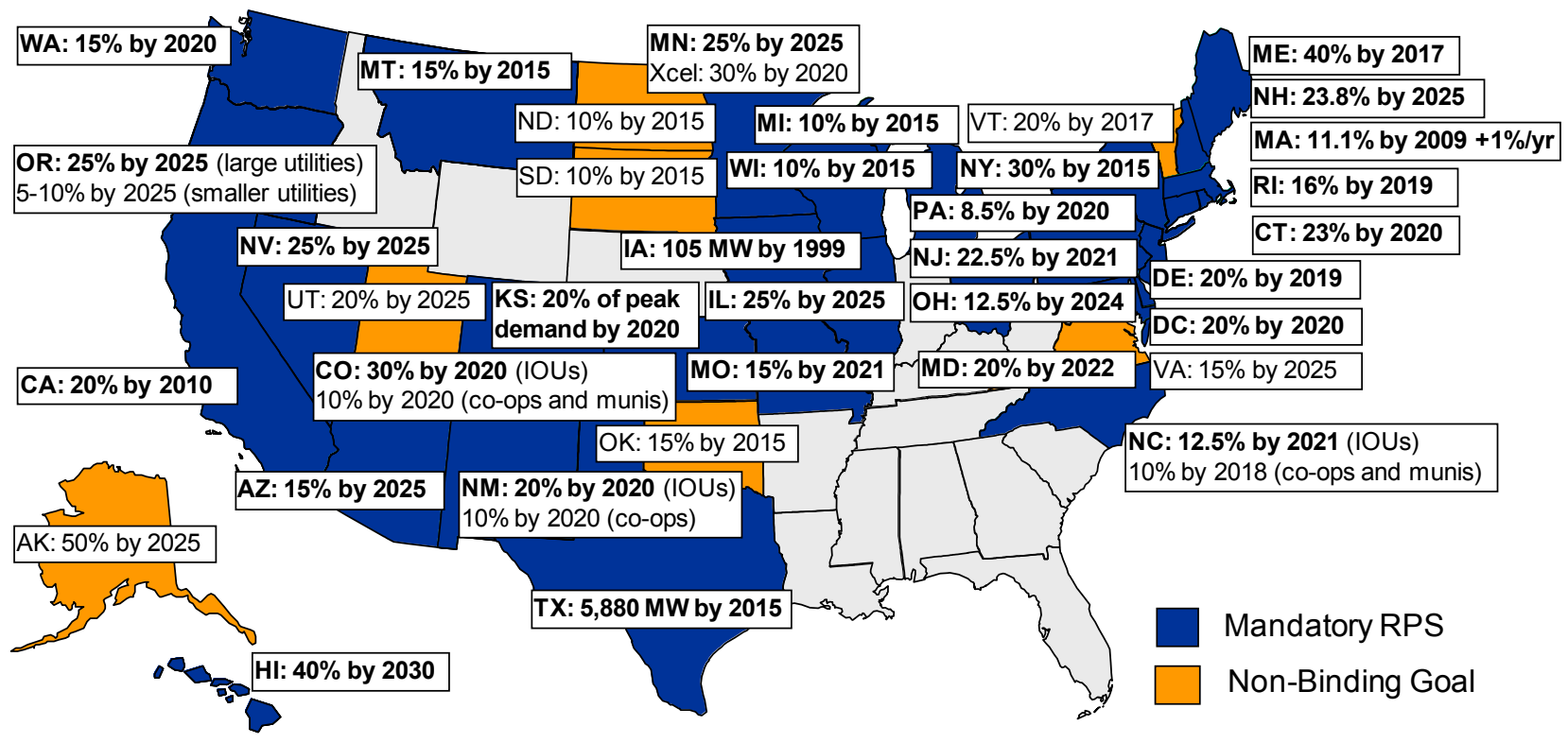

Source: Berkeley Lab

Figure 38. State RPS Policies and Non-Binding Renewable Energy Goals (as of July 2010)

Utility resource planning requirements in Western and Midwestern states have also helped spur wind power additions in recent years (especially as the prospect of future carbon regulations has been included as a variable in resource selection), as has growing voluntary customer demand for "green" power, especially among commercial customers. State renewable energy funds provide 
support for wind power projects (both financial and technical), as do a variety of state tax incentives. Finally, concerns about the possible impacts of global climate change are fueling interest by states and regions (as well as the federal government) to implement carbon reduction policies, a trend that is likely to increasingly underpin wind power expansion in the years ahead. The Northeast's Regional Greenhouse Gas Initiative cap-and-trade policy is now in operation, and carbon policies are also under discussion and being implemented in a number of other regions and states.

\section{Despite Progress on Overcoming Transmission Barriers, Constraints Remain}

Transmission development appears to be gaining some traction. The North American Electric Reliability Corporation (NERC), for example, projects that transmission (100 kV and above) in the United States will increase by 31,400 circuit-miles, or about 8\%, by 2018 (NERC 2009a), while the Brattle Group projects that annual transmission investment will exceed $\$ 10$ billion going forward, compared to roughly $\$ 2$ billion per year in the mid-1990s (Pfeifenberger et al. 2009).

Lack of transmission can be a barrier to wind power development. New transmission is particularly important for wind energy because wind power projects are constrained to areas with adequate wind speeds, which are often located at a distance from load centers. There is a mismatch between the relatively short timeframe needed to develop a wind power project compared to the time typically required to build new transmission. Uncertainty over siting and cost allocation, particularly for multi-state transmission lines, complicates transmission development.

With regards to transmission, several decisions at the federal level in 2009 created some concern among the wind power industry:

- The U.S. Court of Appeals ruled that FERC could use its backstop siting authority if a state withheld its decision for more than a year, but that it did not have the authority to override a state's decision to deny a transmission permit application (U.S. Fourth Circuit Court of Appeals 2009).

- The U.S. Court of Appeals remanded back to FERC the Commission's decision to approve spreading the costs of new transmission facilities above 500-kV in PJM to all transmission customers. Ruling that FERC had to better document how all transmission customers would benefit from the new transmission if all had to share in the cost, the Court's decision added some uncertainty to cost allocation policy (U.S. Seventh Circuit Court of Appeals 2009).

- FERC conditionally approved the Midwest ISO's petition to revise its pre-existing 50-50 cost share methodology to instead charge interconnecting generators $90 \%$ of the costs for transmission facilities rated $345 \mathrm{kV}$ and above, and 100\% for transmission facilities below $345 \mathrm{kV}$, though FERC also directed the Midwest ISO to file a revised cost allocation methodology by July 15, 2010 (FERC 2009). This policy contrasts with FERC's previous approval in 2007 of a California ISO proposal in which the cost of transmission for locationconstrained resources would, initially, be covered in an ISO access charge (FERC 2007a). 
Nonetheless, in June 2010, FERC issued a proposed transmission cost allocation rule that, among other things, would require that local and regional transmission planning processes incorporate the transmission needs that emanate from state or federal policies (such as RPS programs) and would establish principles that cost allocation proposals from grid providers must meet. The FERC proposal also indicates that, if agreement cannot be reached on cost allocation, FERC would itself develop a cost allocation method based on the record in that particular case (FERC 2010c).

States, grid operators, regional organizations, and DOE also continue to take proactive steps to encourage transmission investment to improve access to renewable resources. A non-exhaustive list of examples of these initiatives is presented below:

- Texas Competitive Renewable Energy Zones (CREZ): The Public Utility Commission of Texas (PUCT) encountered a slight delay with its $\$ 5$ billion transmission plan for that state's CREZs. In January 2009, the PUCT awarded the development of CREZ transmission plan segments. The city of Garland challenged the decision, and in December 2009, the Court reversed and remanded the transmission construction allocation order (District Court 2009). The PUCT subsequently assigned the uncontested transmission segments, while creating a new regulatory docket for the reconsideration of the contested transmission segments.

- Southwest Power Pool (SPP): SPP received FERC approval for a new transmission cost allocation methodology in which costs will be paid by load and allocated between SPP and regions based on transmission voltage. Transmission projects of $300 \mathrm{kV}$ and above will be funded $100 \%$ regionally across all of SPP, whereas costs for transmission projects between $100 \mathrm{kV}$ and $300 \mathrm{kV}$ will be allocated 1/3 regionally and 2/3 locally. Costs for transmission projects below $100 \mathrm{kV}$ will be entirely recovered locally (SPP 2010). FERC's approval paves the way for SPP to construct $\$ 1.14$ billion of "Priority Project" transmission in Kansas, Missouri, Oklahoma, and Texas.

- Bonneville Power Administration (BPA) Network Open Season: BPA's second annual network open season was held in June 2009, resulting in 83 transmission service requests for 4,867 MW, of which 2,599 MW were for wind power projects. This process subsequently led to signed transmission agreements for 1,553 MW, including $933 \mathrm{MW}$ of wind power. BPA is also constructing the 500-kV McNary-John Day project, with $\$ 3.25$ billion in increased borrowing authority from the Recovery Act (BPA 2009a); the line is expected to go into service in 2012 and could support $575 \mathrm{MW}$ of new wind power capacity (BPA 2009b).

- Western Area Power Administration (WAPA): WAPA also received authority under the Recovery Act to increase its borrowing authority by up to $\$ 3.25$ billion, and received over 200 transmission proposals to a WAPA-issued request. WAPA has so far made one loan of $\$ 161$ million to Tonbridge Power for the Montana-Alberta Tie Transmission Line (WAPA 2009). Construction of the 230-kV line, primarily being developed to support wind power, is underway and is expected to be completed in 2011 (Tonbridge 2010).

- Interconnection-Wide Transmission Planning: In December 2009, DOE allocated \$60 million in Recovery Act funds to promote collaborative long-term analysis and 
interconnection-wide transmission planning for the Eastern, Western, and Texas interconnections (DOE 2009).

A variety of efforts to proactively plan for transmission, often through analyses of state and regional renewable energy zones, also continued in $2009 .{ }^{60}$ Finally, progress was made in 2009 on some of the transmission projects that are designed, in part, to support wind power, including:

- California Tehachapi: The first three segments of the Tehachapi transmission project were completed in May 2010. Meanwhile, the California PUC approved segments 4-11 in December 2009. Once fully operational, the Tehachapi transmission expansion is expected to be able to accommodate about 4,000 MW of wind power (SCE 2010).

- Texas NextEra Transmission: NextEra built a 200+mile 345-kV line to capture the higher wholesale prices that exist outside of West Texas, where most of wind power capacity is located. The line can transmit up to $950 \mathrm{MW}$ and runs southeast from two of NextEra's wind power projects near Abilene (FPL 2009).

- Maine Transmission: In May 2010, the Maine PUC approved a \$1.4 billion proposal for a 350-mile transmission line that could provide Maine wind power projects greater access to southern New England markets (CMP 2010).

\section{Integrating Wind Energy into Power Systems Is Manageable, but Not Free of Costs, and Market Operators Are Implementing Methods to Accommodate Increased Penetration}

During the past several years, there has been a considerable amount of attention paid to the potential impacts of wind energy on power systems. Concerns about, and solutions to, these issues have affected, and continue to impact, the pace of wind power deployment in the United States

Studies that have evaluated the operational impacts of wind energy on the power system have become increasingly sophisticated, resulting in a better accounting of the potential impacts and integration costs of increased wind energy penetration levels. Key trends among some of the more-recent studies include evaluating even higher levels of wind energy penetration, evaluating the integration of wind energy within larger electricity market areas, and identifying approaches to mitigate integration concerns. Additional recent high-level summaries and examples of wind energy integration in the United States and in other countries are available from IEEE (2009).

\footnotetext{
${ }^{60}$ For example, Xcel Energy submitted a resource zone and transmission plan to the Colorado Public Utilities Commission outlining five wind and solar resource zones, three transmission projects currently being implemented, and six potential transmission projects that would greatly increase renewable energy transfer capability from the zones. The Western Renewable Energy Zones initiative, a collaborative between the Western Governors' Association and the U.S. Department of Energy, completed its Phase 1 report in June 2009. During Phase 1, the project developed a methodology to identify and characterize specific renewable resource-rich areas and created a modeling tool to evaluate the relative economic costs of delivering the renewable energy from the zones to load centers. Arizona's three largest utilities, meanwhile, filed proposals with the Arizona Corporation Commission to build three renewable-oriented transmission projects each. A variety of other state-level renewable energy zone analyses also continued in 2009 .
} 
Two major studies of high penetrations of wind energy, each using different approaches and analysis tools, were completed in early 2010. The Eastern Wind Integration and Transmission Study (EWITS) examined land-based and offshore wind energy in the Eastern Interconnection at penetrations of up to 30\% on an energy basis (EnerNex 2010). The Western Wind and Solar Integration Study (WWSIS) examined wind and solar energy in the Western Interconnection with a particular focus on the WestConnect footprint; the highest penetration examined in the WWSIS was a scenario with 30\% wind and 5\% solar on an energy basis within the WestConnect footprint and 20\% wind and 3\% solar energy in the rest of the Western Interconnection (GE 2010). ${ }^{61}$ Both studies found that, with significant improvements in operational practices, it is technically feasible to operate the power system with high penetrations of wind energy. Changes in operational practices that were found to be beneficial include increased procurement of operating reserves, greater use of sub-hourly generation scheduling, enhanced flexibility and cycling of natural gas and coal plants, incorporation of state-of-the-art wind forecasting into system operations, utilization of demand response, and increased cooperation or consolidation of balancing areas. Although the level of detail in the transmission analysis differed between the two studies, both involved extensive transmission expansion to deliver wind energy resources to load centers and to manage the additional variability and uncertainty.

In addition to these two studies at the interconnection level, Table 9 provides a selective listing of results from wind energy integration cost studies ${ }^{62,63}$ completed from 2003 through early $2010 .{ }^{64}$ Similar information is presented in Figure 39 at various levels of wind power capacity penetration. Because methods vary and a consistent set of operational impacts has not been included in each study, results from the different analyses are not fully comparable. Note also that the rigor with which the various studies have been conducted varies, as does the degree of

\footnotetext{
${ }^{61}$ Wind penetration on a capacity basis (defined as nameplate wind power capacity serving a region divided by that region's peak electricity demand) was frequently used in earlier integration studies. For a given amount of wind power capacity, penetration on a capacity basis is typically higher than the comparable wind penetration in energy terms (because, over the course of a year, wind power projects generally operate at a lower percentage of their rated capacity, on average, than do many other resources). The energy penetration levels in the EWITS study correspond to $48 \%$ wind on a capacity basis. The energy penetration levels in the WWSIS study correspond to penetrations of $52 \%$ wind and $10 \%$ solar in the WestConnect and 38\% wind and $6 \%$ solar in the rest of the Western Electricity Coordinating Council on a capacity basis.

${ }^{62}$ The integration costs considered in these studies typically refer to the costs associated with accommodating the variability and uncertainty associated with wind energy. Generally, these costs are associated with three different time frames: regulation - from seconds to a few minutes; load-following - tens of minutes to a few hours; and unit commitment - out to the next day or two. Studies often, but not always, estimate these costs as the difference in overall electric system production costs between a scenario that captures the variability and unpredictability of wind energy and a scenario with an energy-equivalent block of power having no variability or uncertainty.

${ }^{63}$ Several additional studies focus on the operational impacts of wind energy and/or on the overall production-cost reduction value of wind energy, without an explicit comparison to an energy-equivalent block of power having no variability or uncertainty. These studies are not included in the table because they do not seek to explicitly calculate integration costs. Examples of such studies include: the Western Wind and Solar Integration Study, (GE 2010); a 2010 study of wind energy integration into the Southwest Power Pool (Charles River Associates 2010); a 2008 study on the ancillary service implications of high wind energy penetration in ERCOT (GE 2008); two integration studies for California from 2007 by the California ISO (CAISO 2007) and by the California Energy Commission's Intermittency Analysis Project (Piwko et al. 2007); and a study for New York in 2005 (GE 2005).

${ }^{64}$ Some of the studies included in the table also address capacity valuation for resource adequacy purposes; those results are not presented here.
} 
peer review. Nonetheless, key conclusions that continue to emerge from the growing body of integration literature include the following:

- Wind energy integration costs are below $\$ 10 / \mathrm{MWh}$ - and often below $\$ 5 / \mathrm{MWh}$ - for wind power capacity penetrations up to or exceeding $40 \%$ of the peak load of the system in which the wind power is delivered. ${ }^{65}$ Variations in estimated costs across studies are due, in part, to differences in methodologies, definitions of integration costs, power system and market characteristics, wind energy penetration levels, and fuel price assumptions.

- Regulation impacts are often found to be relatively small, whereas the impacts of wind energy on load-following and unit commitment are typically found to be more significant.

- Larger balancing areas, such as those found in RTOs and ISOs, make it possible to integrate wind energy more easily and at lower cost than is the case in smaller balancing areas.

- The successful use of wind power forecasts by system operators can significantly reduce integration challenges and costs. Wind forecasts are most accurate and effective when aggregated across large, electrically interconnected areas.

- Intra-hour scheduling (e.g., 5-10 minute schedules) provides access to flexibility in conventional power plants that lowers the costs of integrating wind energy.

- Wind energy integration costs tend to rise with increasing natural gas prices, though the economic value of wind energy also increases with higher gas prices.

\footnotetext{
${ }^{65}$ The relatively low cost estimates in the 2006 Minnesota study and the 2010 Nebraska study, despite aggressive levels of wind energy penetration, are partly a result of relying on the broader regional electricity market to accommodate certain elements of integrating wind energy into system operations. Conversely, the higher integration costs found by Avista and Idaho Power are, in part, caused by the relatively smaller markets in which the wind energy is being absorbed and by those utilities' operating practices. Specifically, the Northwest currently uses hourly scheduling intervals rather than the sub-hourly markets common in ISOs and RTOs. A sensitivity case in the Avista Utilities study demonstrates that the use of a 10-minute transaction scheduling interval would decrease the cost of integrating wind energy by $40-60 \%$.
} 
Table 9. Key Results from Selected Wind Energy Integration Cost Studies ${ }^{66}$

\begin{tabular}{|c|c|c|c|c|c|c|c|}
\hline \multirow[b]{2}{*}{ Year } & \multirow[b]{2}{*}{ Study } & \multirow{2}{*}{$\begin{array}{c}\text { Wind } \\
\text { Capacity } \\
\text { Penetration }\end{array}$} & \multicolumn{5}{|c|}{ Integration Cost (\$/MWh) } \\
\hline & & & Regulation & $\begin{array}{c}\text { Load } \\
\text { Following }\end{array}$ & $\begin{array}{c}\text { Unit } \\
\text { Commit. }\end{array}$ & $\begin{array}{c}\text { Gas } \\
\text { Supply }\end{array}$ & TOTAL \\
\hline 2003 & Xcel-UWIG & $3.5 \%$ & 0 & 0.41 & 1.44 & - & 1.85 \\
\hline 2003 & We Energies & $29 \%$ & 1.02 & 0.15 & 1.75 & - & 2.92 \\
\hline 2004 & Xcel-MNDOC & $15 \%$ & 0.23 & - & 4.37 & - & 4.60 \\
\hline 2005 & PacifiCorp-2004 & $11 \%$ & 0 & 1.48 & 3.16 & - & 4.64 \\
\hline 2006 & Calif. (multi-year)* & $4 \%$ & 0.45 & trace & trace & - & 0.45 \\
\hline 2006 & Xcel-PSCo & $15 \%$ & 0.20 & - & 3.32 & 1.45 & 4.97 \\
\hline 2006 & MN-MISO** & $31 \%$ & - & - & - & - & 4.41 \\
\hline 2007 & Puget Sound Energy & $12 \%$ & - & - & - & - & 6.94 \\
\hline 2007 & Arizona Pub. Service & $15 \%$ & 0.37 & 2.65 & 1.06 & - & 4.08 \\
\hline 2007 & Avista Utilities & $30 \%$ & 1.43 & 4.40 & 3.00 & - & 8.84 \\
\hline 2007 & Idaho Power & $20 \%$ & - & - & - & - & 7.92 \\
\hline 2007 & PacifiCorp-2007 & $18 \%$ & - & 1.10 & 4.00 & - & 5.10 \\
\hline 2008 & Xcel-PSCo $* * *$ & $20 \%$ & - & - & - & - & 8.56 \\
\hline 2009 & Bonneville (BPA) $^{+}$ & $36 \%$ & 0.22 & 1.14 & - & - & 5.70 \\
\hline 2010 & EWITS $^{++}$ & $48 \%$ & - & - & 1.61 & - & 4.54 \\
\hline 2010 & Nebraska $^{++}$ & $63 \%$ & - & - & - & - & 1.75 \\
\hline \multicolumn{8}{|c|}{$\begin{array}{l}\text { * Regulation costs represent 3-year average. } \\
\text { ** Highest over 3-year evaluation period. } \\
\text { *** This integration cost reflects a } \$ 10 / \mathrm{MMBtu} \text { natural gas price scenario. This cost is much higher than the } \\
\text { integration cost calculated for Xcel-PSCo in } 2006 \text {, in large measure due to the higher natural gas price: had the gas } \\
\text { price from the } 2006 \text { study been used in the } 2008 \text { study, the integration cost would drop to } \$ 5.13 / \mathrm{MWh} \text {. } \\
+ \text { Costs in } \$ / \mathrm{MWh} \text { assume } 31 \% \text { capacity factor. Aside from regulation and following reserves, the costs of BPA's } \\
\text { imbalance reserves are } \$ 4.33 / \mathrm{MWh} \text {. } \\
\text { ++ The unit commitment costs listed in EWITS are the cost of day-ahead wind forecast error; the remaining } \\
\text { integration costs included in the total are for shorter term variable reserves that account for regulation and short-term } \\
\text { forecast errors (energy imbalance). } \\
\text { +++ These integration costs only capture regulating reserves and day-ahead forecast error. A sensitivity case in this } \\
\text { study shows that integration costs increase if the differences between the actual hourly deliveries of wind energy are } \\
\text { compared to daily flat block of power. The increased costs are shown in Figure } 39 \text {. }\end{array}$} \\
\hline
\end{tabular}

Sources: Brooks et al. (2003) [Xcel-UWIG]; Electrotek Concepts, Inc. (2003) [We Energies]; EnerNex Corp. and Wind Logics, Inc. (2004) [Xcel-MNDOC]; PacifiCorp (2005) [Pacificorp-2004]; Shiu et al. (2006) [Calif. (multiyear)]; EnerNex Corp. (2006) [Xcel-PSCo]; EnerNex Corp. and Windlogics Inc. (2006) [MN-MISO]; Puget Sound Energy (2007) [Puget Sound Energy]; Acker (2007) [Arizona Pub. Service]; EnerNex Corp. (2007) [Avista Utilities]; EnerNex Corp. and Idaho Power Co. (2007) [Idaho Power]; PacifiCorp (2007) [PacifiCorp-2007]; EnerNex Corp. (2008) [Xcel-PSCo]; BPA (2009) [Bonneville]; EnerNex Corp (2010) [EWITS]; EnerNex et al. (2010) [Nebraska]

\footnotetext{
${ }^{66}$ Two estimates of integration costs from 2009 are not included in this table due to ongoing efforts to refine the methodologies and/or incomplete documentation those methodologies. The first study, from PacifiCorp, estimated integration cost to be $\$ 11.85 / \mathrm{MWh}$ at a $22 \%$ wind power capacity penetration level, assuming a $\$ 45 /$ ton CO2 tax. With a lower CO2 tax of $\$ 8 /$ ton, estimated integration costs decreases to $\$ 9.96 / \mathrm{MWh}$ (PacifiCorp 2009). The second study, from Portland General Electric, estimated integration costs to be $\$ 11.75 / \mathrm{MWh}$ at a $27 \%$ wind power capacity penetration level (PGE 2009). If and when refined estimates and more complete documentation of study methodologies become available, these results will be included in the main body of this report..
} 


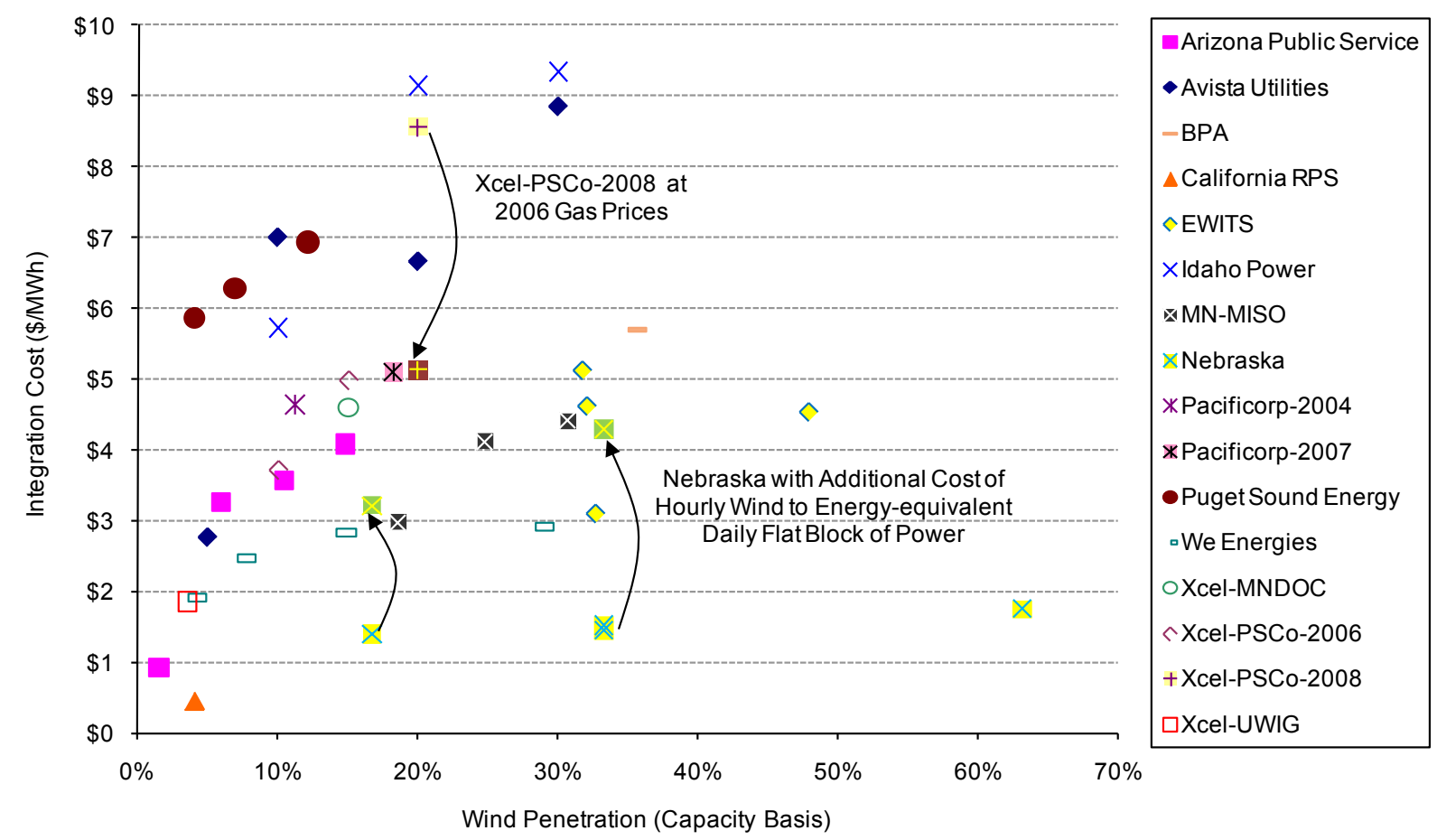

Source: See Table 9

\section{Figure 39. Integration Costs at Various Levels of Wind Power Capacity Penetration}

Many ISOs and utilities are also continuing to take important steps to mitigate the challenges faced with integrating larger quantities of wind energy. Centralized wind forecasting systems are currently in place at the PJM, Electric Reliability Council of Texas, Midwest ISO, New York ISO, California ISO, Southern California Edison, and Xcel Energy; while the BPA is currently developing wind forecasting systems (Porter and Rogers 2010). Northern Tier Transmission Group, Columbia Grid, and WestConnect, meanwhile, are jointly investigating projects that will increase power system flexibility, including the creation of a dynamic scheduling communications infrastructure, sharing of area control errors, and intra-hour scheduling and balancing. These initiatives have broad benefits, including better utilization of the transmission system and providing increased flexibility to integrate wind energy.

Some utilities are now directly charging wind power projects for balancing services or are reducing posted 'avoided cost' contract price payments to account for the costs of integrating wind energy. BPA, for example, includes a wind energy balancing charge in its transmission tariff equivalent to about $\$ 5.70 / \mathrm{MWh}$. FERC conditionally approved a higher generator regulation and frequency response services charge for wind energy in the Westar Energy balancing area equivalent to about $\$ 0.80 / \mathrm{MWh}$; this tariff is still in FERC proceedings and may be revised (FERC 2010a). Idaho Power, Avista, and PacifiCorp, meanwhile, all discount their avoided cost payments for qualifying wind power projects by an integration rate that ranges from $7-9 \%$ of the avoided cost rate, up to $\$ 6.50 / \mathrm{MWh}$ (IPUC 2010).

At a national level, NERC and FERC have also been focused on identifying methods to reliably and economically integrate wind energy into the bulk power system. NERC released a 
comprehensive report in 2009 with several recommendations for changing planning and operational procedures to maintain reliable operation with high levels of variable generation (NERC 2009b). Following the report, NERC outlined a three-year work plan to further develop and improve standards and practices for integrating variable generation. FERC, meanwhile, issued a notice of inquiry seeking public comment on whether to reform any of its rules or procedures to ensure that increased amounts of variable energy resources can be accommodated with just and reasonable rates and without undue discrimination (FERC 2010b). Over one hundred reply comments have been filed by parties throughout the United States proposing potential steps to better facilitate the integration of variable generation. 


\section{Future Outlook}

Despite the growth in installed capacity in 2009, the combination of the financial crisis, lower wholesale electricity prices, and lower demand for renewable energy has taken a toll on the wind power industry. During 2009, the relative economic position of wind energy became more challenging, orders for new turbines slowed, and turbine and component manufacturers announced some layoffs. Wind power capacity additions in 2009 were buoyed, in part, by projects that were initially slated to be completed in 2008 but that carried over into 2009 when the PTC was extended, somewhat masking the underlying challenges facing the sector. With federal incentives now extended through 2012, there is less motivation to complete projects in 2010 (though many projects will likely start construction in 2010 in order to qualify for the $30 \%$ Treasury cash grant). As a result, though the Recovery Act has helped to alleviate financing challenges, expectations of a slower year in 2010 remain.

A variety of forecasts suggest that wind power installations in 2010 may fall within the range of $5,500 \mathrm{MW}$ to $8,000 \mathrm{MW}$, a drop of $20-45 \%$ compared to the nearly $10,000 \mathrm{MW}$ installed in 2009 (see Table 10). This contraction is reflected in results for the first half of 2010, in which just 1,240 MW of wind power were installed - i.e., 57\% less than the amount installed in the first half of 2008, and 71\% below the pace set in the first half of 2009 (AWEA 2010c). After a slower year in 2010, these predictions show market resurgence in 2011 and 2012, with annual installations ranging from 8,100 to $15,000 \mathrm{MW}$ depending on the forecast and year. From 2010 through 2012, these forecasts predict cumulative wind power additions of 24 to $33 \mathrm{GW}$; this amount of new wind power capacity would provide roughly $30-40 \%$ of EIA's projected growth in total U.S. electricity demand over the 2010-2012 timeframe. Though not shown in Table 10, any projections beyond 2012 are rendered considerably less certain by the scheduled expiration of a number of policies at the end of that year, including the PTC, the ability to elect a 30\% ITC in lieu of the PTC, and the ability to receive the $30 \%$ cash grant for projects that initiated construction by the end of 2010 .

Table 10. Forecasts for Annual U.S. Wind Capacity Additions (MW)

\begin{tabular}{|l|c|c|c|c|}
\hline Source & $\mathbf{2 0 1 0}$ & $\mathbf{2 0 1 1}$ & $\mathbf{2 0 1 2}$ & $\begin{array}{c}\text { Cumulative Additions } \\
\mathbf{2 0 1 0 - 2 0 1 2}\end{array}$ \\
\hline EIA & 7,310 & 10,200 & 10,330 & 27,840 \\
\hline BTM & 8,000 & 10,000 & 15,000 & 33,000 \\
\hline IHS EER & 7,130 & 9,830 & 9,340 & 26,300 \\
\hline Bloomberg NEF & 7,390 & 8,535 & 8,610 & 24,535 \\
\hline Macquarie & 7,500 & 8,100 & 8,700 & 24,300 \\
\hline UBS & 6,950 & 9,380 & 10,780 & 27,110 \\
\hline AWEA & $5,500-7,500$ & -- & -- & -- \\
\hline
\end{tabular}

Source: Bloomberg NEF (2010b), BTM (2010), EIA (2010), IHS Emerging Energy Research (2010), Macquarie (2010), UBS (2010), AWEA (2010c)

Notwithstanding the anticipated slowdown in 2010, these growth projections would likely ensure that the United States retains its 2009 position as the second-largest wind energy market in the world in terms of annual capacity additions. Driven by rapidly growing energy demands and 
strong policy support, China is widely expected to lead to the world in annual wind power capacity additions in the coming years. Industrial policy and market conditions have also resulted in the growing dominance of Chinese wind turbine manufacturers within the Chinese market, and those manufacturers are beginning to explore export strategies. U.S. manufacturing of turbines and components is also expected to continue to grow, as already-announced manufacturing facilities come on line, as existing facilities reach full capacity and expand, and as new announcements and investments are made. In part as a result, and in a continuation of recent trends, the historically-dominant wind turbine suppliers in the United States market are likely to face growing competition from new entrants over this timeframe.

Uncertainties about market performance even over the 2010-2012 timeframe are the result of underlying uncertainties about market and policy drivers. On the positive side, the wind power industry now has stronger federal policy support than at any time in the last decade, and state policies have become more aggressive. Additionally there are prospects for further federal policy support through some combination of a continuation of (or variants to) the Treasury Grant program, federal RPS legislation, climate legislation, and policies intended to spur new transmission investments, as well as continued state renewable energy and climate policy initiatives. With wind turbine prices now dropping, the trend of increasing project-level costs and prices experienced over the last several years is also expected to slow and even reverse, improving the comparative economic position of wind.

On the other hand, with the window of eligibility for the Treasury Grant program scheduled to close at the end of 2010 and the tax equity market for wind energy not fully recovered, near-term growth may be hampered. Natural gas prices and near-term price expectations have plummeted, making wind energy's primary competitor more economically attractive than in recent years. And, with the much-lower wholesale electricity price environment, merchant wind power development - which had grown dramatically in recent years - may slow. The significant wind energy growth in recent years has also exceeded aggregate state RPS demands, resulting in softer demand from state RPS markets in the near term. Wind power additions are increasingly constrained by inadequate transmission infrastructure, and while progress is being made to alleviate those constraints, the build-out of transmission infrastructure will take time. Finally, in California and the Southwest in particular, wind energy is beginning to face stiff competition with solar energy in meeting state renewable energy requirements.

Regardless of these competing trends, wind power capacity additions over the past several years, and those projected from 2010-2012, put the United States on a trajectory that may lead to 20\% of the nation's electricity demand coming from wind energy by 2030. In May 2008, the U.S. Department of Energy, in collaboration with its national laboratories, the wind power industry, and others, published a report that analyzed the technical and economic feasibility of achieving $20 \%$ wind energy penetration by 2030 (DOE 2008). In addition to finding no insurmountable barriers to reaching $20 \%$ wind energy penetration, the report also laid out a potential wind power deployment path that started at $3.3 \mathrm{GW} /$ year in 2007 , increasing to $4.2 \mathrm{GW} /$ year by $2009,6.4$ $\mathrm{GW} /$ year by $2011,9.6 \mathrm{GW} /$ year by $2013,13.4 \mathrm{GW} /$ year by 2015 , and roughly $16 \mathrm{GW} /$ year by 2017 and thereafter, yielding cumulative wind power capacity of $305 \mathrm{GW}$ by 2030 . Historical growth over the last four years puts the United States on a trajectory exceeding this deployment 
path, and the projected growth presented in Table 10 would ensure that the United States remains in that position through 2012 (Figure 40).

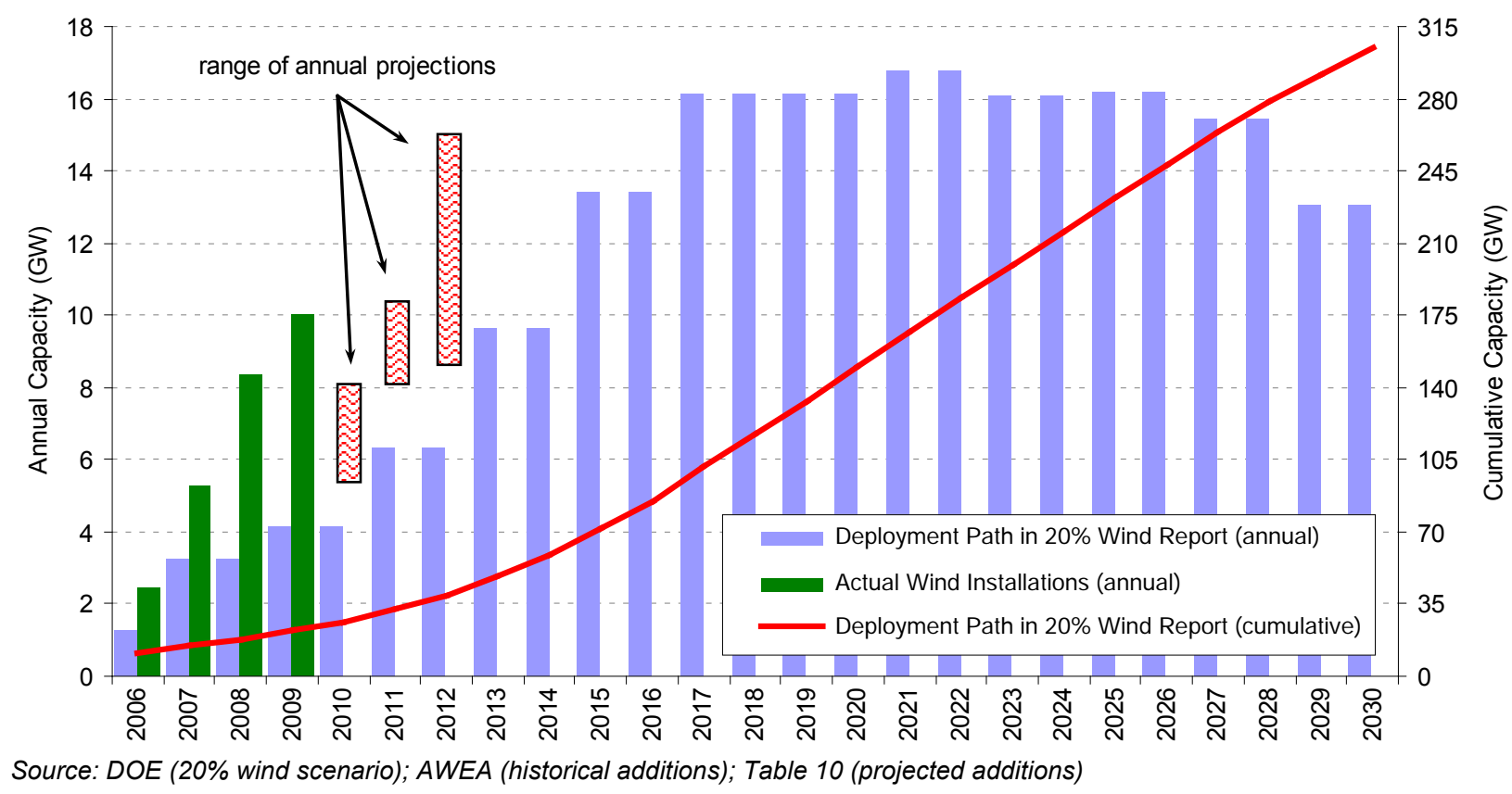

Figure 40. Wind Power Capacity Growth: $20 \%$ Wind Report, Actual Installations, Projected Growth

Ramping up to an annual installation rate of $16 \mathrm{GW}$ per year, and maintaining that rate for a decade, is, however, far from pre-determined. The record $10 \mathrm{GW}$ installation pace in 2009 was achieved, in part, because of the previously-pending end-of-2008 expiration of the PTC. Moreover, federal policy towards wind energy remains uncertain after 2012. Whether the roughly $16 \mathrm{GW}$ per year pace needed for wind power to contribute $20 \%$ of the nation's electricity by 2030 can be achieved and maintained remains to be seen.

In addition to stable, long-term promotional policies, the DOE (2008) report suggests four other areas where supportive actions may be needed in order to reach such annual installation rates. First, the nation will need to invest in significant amounts of new transmission infrastructure designed to access remote wind resources. Second, to more-effectively integrate wind power into electricity markets, larger power control regions, better wind forecasting, and increased investment in fast-responding generating plants will be required. Third, streamlined siting and permitting procedures will need to be established to allow wind power developers to identify appropriate project locations and move from wind resource prospecting to construction quickly. Finally, enhanced research and development efforts in both the public and private sector will be required to lower the cost of offshore wind power, and incrementally improve conventional landbased wind energy technology. 


\section{Appendix: Sources of Data Presented in this Report}

\section{Installation Trends}

Data on wind power additions in the United States come from AWEA, though methodological differences noted throughout this report result in some difference in the data presented here relative to AWEA (2010a). Annual wind power capital investment estimates derive from multiplying these wind power capacity data by weighted-average capital cost data, provided elsewhere in the report. Data on non-wind electric capacity additions come primarily from EIA (for years prior to 2009) and Ventyx's Velocity database (for 2009), except that solar data come from the Interstate Renewable Energy Council (IREC) and Berkeley Lab. Data on the small wind turbine market come from AWEA (2010b). Information on offshore wind power development activity in the United States was compiled by Berkeley Lab, NREL, and Energetics.

Global cumulative (and 2009 annual) wind power capacity data come from BTM (2010), but are revised to include the U.S. wind power capacity used in the present report. Historical cumulative and annual worldwide capacity data come from BTM Consult and the Earth Policy Institute.

Wind energy as a percentage of country-specific electricity consumption is based on end-of-2009 (and end-of-2006/07/08) wind power capacity data and country-specific assumed capacity factors that primarily come from BTM (2010). For the United States, the performance data presented in this report are used to estimate wind energy production. Country-specific projected wind generation is then divided by projected electricity consumption in 2010 (and 2007/08/09), based on actual 2007 consumption and a country-specific growth rate assumed to be the same as the rate of growth from 2002 through 2007 (these data come from EIA).

The wind power project installation map was created by NREL, based in part on AWEA's database of projects and in part on data from Platts on the location of individual projects. Effort was taken to reconcile the AWEA project database and the Platts-provided project locations, though some discrepancies remain. Wind energy as a percentage contribution to statewide electricity generation is based on AWEA installed capacity data for the end of 2009 and the underlying wind power project performance data presented in this report. Where necessary, judgment was used to estimate state-specific capacity factors. The resulting state wind generation is then divided by in-state total electricity generation in 2009 , based on EIA data.

The listing of wind power capacity serving specific electric utilities comes from AWEA's U.S. Wind Industry Annual Market Report (AWEA 2010a), with two exceptions: (1) the Empire District Electric Company was added to AWEA's "top twenty" investor-owned utility list at position number 14; and (2) Minnkota Power Cooperative's wind capacity was corrected to 357 MW (AWEA (2010a) shows $290 \mathrm{MW).} \mathrm{To} \mathrm{translate} \mathrm{this} \mathrm{capacity} \mathrm{to} \mathrm{projected} \mathrm{utility-specific}$ annual electricity generation, regionally appropriate wind power capacity factors are used. The resulting utility-specific projected wind generation is then divided by the aggregate national retail sales of each utility in 2008 (based on EIA Form-861 data). Only utilities with $100 \mathrm{MW}$ or more of wind power capacity are included in these calculations. In the case of G\&T cooperatives and power authorities that provide power to other cooperatives and municipal utilities (but do not directly serve load themselves), this report uses 2008 retail sales from the electric utilities served by those G\&T cooperatives and power authorities. In some cases, these individual utilities may be buying additional wind directly from other projects, or may be served 
by other G\&T cooperatives or power authorities that supply wind. In these cases, the penetration percentages shown in the report may be somewhat misleading.

Data on wind power capacity in various interconnection queues come from a review of publicly available data provided by each ISO, RTO, or utility. Only projects that were active in the queue at the end of 2009, but that had not yet been built, are included. Suspended projects are not included in these listings. Data on projects that are in the nearer-term development pipeline come from Ventyx (2010).

\section{Industry Trends}

Turbine manufacturer market share, average turbine size, and average project size are derived from the AWEA wind power project database, with some processing by Berkeley Lab.

Information on turbine hub heights and rotor diameters were compiled by Berkeley Lab based on information provided by turbine manufacturers, standard turbine specifications, FAA data, web searches, and other sources.

Information on wind turbine and component manufacturing come from NREL, AWEA, and Berkeley Lab, based on a review of press reports, personal communications, and other sources. The listings of manufacturing and supply chain facilities are not intended to be exhaustive. Data on aggregate U.S. imports and exports of wind power equipment come primarily from the U.S. International Trade Commission, and can be obtained from the USITC's DataWeb (http://dataweb.usitc.gov/).

Information on wind power developer consolidation and financing trends were compiled by Berkeley Lab. Wind project ownership and power purchaser trends are based on a Berkeley Lab analysis of the AWEA project database.

\section{Price, Cost, and Performance Trends}

Wind power price data are based on multiple sources, including prices reported in FERC's Electronic Quarterly Reports, FERC Form 1, avoided cost data filed by utilities, pre-offering research conducted by bond rating agencies, and a Berkeley Lab collection of power purchase agreements. Wholesale electricity price data were compiled by Berkeley Lab from the IntercontinentalExchange (ICE) as well as Ventyx's Velocity database (which itself derives wholesale price data from the ICE and the various ISOs). Earlier years' wholesale electricity price data come from FERC (2007b, 2005). REC price data were compiled by Berkeley Lab based on information provided by Evolution Markets and Spectron.

Berkeley Lab used a variety of public and some private sources of data to compile capital cost data for a large number of U.S. wind power projects. Data sources range from pre-installation corporate press releases to verified post-construction cost data. Specific sources of data include: EIA Form 412, FERC Form 1, various Securities and Exchange Commission filings, various filings with state public utilities commissions, Windpower Monthly magazine, AWEA's Wind Energy Weekly, DOE/EPRI's Turbine Verification Program, Project Finance magazine, various analytic case studies, and general web searches for news stories, presentations, or information from project developers. For 2009 projects, data from the Section 1603 Treasury Grant program were used extensively. Some data points are suppressed in the figures to protect data 
confidentiality. Because the data sources are not equally credible, little emphasis should be placed on individual project-level data; instead, it is the trends in those underlying data that offer insight. Only wind power cost data from the contiguous lower-48 states are included.

Wind turbine transaction prices were compiled by Berkeley Lab. Sources of transaction price data vary, but most derive from press releases and press reports. In part because wind turbine transactions vary in the services offered, a good deal of intra-year variability in the cost data is apparent. Additionally, the data do not adequately capture the rumored softening of the wind turbine market since late 2008, as relative few publicly reported wind turbine sales transactions exist since that time.

Wind power project performance data are compiled overwhelmingly from two main sources: FERC's Electronic Quarterly Reports and EIA Form 923. Additional data come from FERC Form 1 filings and, in several instances, other sources. Where discrepancies exist among the data sources, those discrepancies are handled based on the judgment of Berkeley Lab staff. Data on curtailment in Texas are from ERCOT and in the Midwest from MISO.

Wind project operations and maintenance costs come primarily from two sources: EIA Form 412 data from 2001-2003 for private power projects and projects owned by POUs, and FERC Form 1 data for IOU-owned projects. Some data points are suppressed in the figures to protect data confidentiality.

\section{Policy and Market Drivers}

The wind energy integration, transmission, and policy sections were written by staff at Berkeley Lab and Exeter Associates, based on publicly available information.

\section{Future Outlook}

This section was written by staff at Berkeley Lab, based largely on publicly available information. 


\section{References}

Acker, T. 2007. Arizona Public Service Wind Integration Cost Impact Study. Prepared for Arizona Public Service Company. Flagstaff, Arizona: Northern Arizona University.

American Wind Energy Association (AWEA). 2010a. U.S. Wind Industry Annual Market Report: Year Ending 2009. Washington, DC: American Wind Energy Association.

American Wind Energy Association (AWEA). 2010b. AWEA Small Wind Turbine Global Market Survey, Year Ending 2009. Washington, DC: American Wind Energy Association.

American Wind Energy Association (AWEA). 2010c. AWEA Mid-Year 2010 Market Report. Washington, DC: American Wind Energy Association.

Bailey, D. 2010. "Wind developers shun US federal loan programme." Windpower Monthly. 26(4): 32-34.

Bloomberg New Energy Finance. 2010a. Q1 Wind Market Outlook. February 2010. Bloomberg New Energy Finance.

Bloomberg New Energy Finance. 2010b. Q2 Wind Market Outlook. June 2010. Bloomberg New Energy Finance.

Bolinger, M., R. Wiser, N. Darghouth. 2010. Preliminary Evaluation of the Impact of the Section 1603 Treasury Grant Program on Renewable Energy Deployment in 2009. LBNL-3188E. Berkeley, California: Lawrence Berkeley National Laboratory.

BPA. 2009a. Summary of Eligible TSRs for 2009 Network Open Season. July 22, 2009. http://www.transmission.bpa.gov/customer_forums/open_season_2009/NOS_Eligibility_su mmary 07-22-09.pdf

BPA. 2009b. McNary-John Day 500-kilovolt Transmission Line. September 9, 2009. http://www.bpa.gov/corporate/RecoveryAct/mcnary-johnday.cfm

Brooks, D., E. Lo, R. Zavadil, S. Santoso, J. Smith. 2003. Characterizing the Impact of Significant Wind Generation Facilities on Bulk Power System Operations Planning: Xcel Energy - North Case Study. Prepared for the Utility Wind Integration Group. Arlington, Virginia: Electrotek Concepts.

BTM Consult. 2010. International Wind Energy Development: World Market Update 2009. Ringkobing, Denmark: BTM Consult ApS.

California ISO (CAISO). 2007. Integration of Renewable Resources. Folsom, California: California Independent System Operator.

Chadbourne \& Parke. 2010a. "Update: Tax Equity Market." Project Finance Newswire. April 2010. pp. 8-20.

Chadbourne \& Parke. 2010b. "The Search for Lowest Cost Capital." Project Finance Newswire. July 2010. pp. 1-9.

Charles River Associates. 2010. SPP WITF Wind Integration Study. Little Rock, Arkansas: Southwest Power Pool. 
CMP. 2010. Maine Utility Regulators Approve \$1.4 Billion Transmission Line Investment. May 14, 2010. http:/www.cmpco.com/OurCompany/News/2010/news100514.html

David, A. 2009. Wind Turbines: Industry and Trade Summary. ITX-02. Washington, DC: U.S. International Trade Commission.

David, A. 2010. Impact of Wind Energy Installations on Domestic Manufacturing and Trade. ID-25. Washington, DC: U.S. International Trade Commission.

Department of Energy (DOE). 2008. 20\% Wind Energy by 2030: Increasing Wind Energy's Contribution to U.S. Electricity Supply. DOE/GO-102008-2567. Washington, D.C.: U.S. Department of Energy.

Department of Energy (DOE). 2009. Secretary Chu Announces Efforts to Strengthen U.S. Electric Transmission Networks. December 18, 2009. http://www.energy.gov/news/8408.htm

District Court. 2009. City of Garland vs. Public Utility Commission of Texas. January 15, 2010.

Electrotek Concepts, Inc. 2003. Systems Operations Impacts of Wind Generation Integration Study. Prepared for We Energies. Knoxville, Tennessee: Electrotek Concepts.

Energy Information Administration (EIA). 2010. Annual Energy Outlook 2010. DOE/EIA0383(2010). Washington D.C.: Energy Information Administration.

EnerNex Corp. 2006. Wind Integration Study for Public Service Company of Colorado. Prepared for Xcel Energy. Denver, Colorado.

EnerNex Corp. 2007. Final Report Avista Corporation Wind Integration Study. Knoxville, Tennessee: EnerNex Corporation.

EnerNex Corp. 2008. Wind Integration Study for Public Service of Colorado, Addendum, Detailed Analysis of 20\% Wind Penetration. Prepared for Xcel Energy. Denver, Colorado: Xcel Energy.

EnerNex Corp. 2010. Eastern Wind Integration and Transmission Study. NREL/SR-550-47078. Golden, Colorado: National Renewable Energy Laboratory.

EnerNex Corp. and Idaho Power Co. 2007. Operational Impacts of Integrating Wind Generation into Idaho Power's Existing Resource Portfolio: Report Addendum. Boise, Idaho: Idaho Power Company.

EnerNex Corp., Ventyx, and Nebraska Power Association. 2010. Nebraska Statewide Wind Integration Study. NREL/ SR-550-47519. Golden, Colorado: National Renewable Energy Laboratory.

EnerNex Corp. and Wind Logics, Inc. 2004. Wind Integration Study-Final Report. Prepared for Xcel Energy and Minnesota Department of Commerce. Knoxville, Tennessee: EnerNex Corporation.

EnerNex Corp. and Windlogics Inc. 2006. Final Report - 2006 Minnesota Wind Integration Study, Volume I. Prepared for the Minnesota Public Utilities Commission. Knoxville, Tennessee: EnerNex Corporation.

ERCOT. 2010. Personal communication with Dan Jones, ERCOT Independent Market Monitor. February 2010. 
European Wind Energy Association (EWEA). 2010. Wind in Power: 2009 European Statistics. Brussels, Belgium: European Wind Energy Association.

Federal Energy Regulatory Commission (FERC). 2005. 2004 State of the Markets Report. Washington, DC: Federal Energy Regulatory Commission.

Federal Energy Regulatory Commission (FERC). 2007a. Order Granting Petition for Declaratory Order. 119 FERC \ 61,061, April 19, 2007.

Federal Energy Regulatory Commission (FERC). 2007b. 2006 State of the Markets Report. Washington, DC: Federal Energy Regulatory Commission.

Federal Energy Regulatory Commission (FERC). 2009. Midwest Independent Transmission System Operator, Inc. and The Midwest ISO Transmission Owners. 129 FERC $\uparrow$ 61,060.

Federal Energy Regulatory Commission (FERC). 2010a. Order conditionally accepting proposed tariff revisions re Westar Energy, Inc. under ER09-1273. 130 FERC \ 61,215.

Federal Energy Regulatory Commission (FERC). 2010b. Notice of Inquiry Seeking Public Comment on the Integration of Variable Energy Resources under RM10-11. Washington D.C.: Federal Energy Regulatory Commission.

Federal Energy Regulatory Commission (FERC). 2010c. Transmission Planning and Cost Allocation by Transmission Owning and Operating Public Utilities. 131 FERC 9 61,253.

FPL. 2009. FPL Group, Inc. Q3 2009 Earnings Call Transcript. October 27, 2009. http://seekingalpha.com/article/169267-fpl-group-inc-q3-2009-earnings-calltranscript?page $=-1$.

GE Energy. 2005. The Effects of Integrating Wind Power on Transmission System Planning, Reliability, and Operations: Report on Phase 2. Prepared for the New York State Energy Research \& Development Authority. Schenectady, New York: GE Energy.

GE Energy. 2008. Analysis of Wind Generation Impact on ERCOT Ancillary Services Requirements. Prepared for the Electricity Reliability Council of Texas. Schenectady, New York: GE Energy.

GE Energy. 2010. Western Wind and Solar Integration Study. NREL/SR-550-47434. Golden, Colorado: National Renewable Energy Laboratory.

Idaho Public Utilities Commission. 2010. In the Matter of the Petition of Pacificorp dba Rocky Mountain Power for an Order Revising the Wind Integration Rate for Wind Powered Small Power Generation Qualifying Facilities. PAC-E-09-07 Order No. 31021. March 12, 2010.

IEEE Power and Energy Magazine. 2009. An Update on Wind Integration, 7(6), NovemberDecember.

IHS CERA. 2009. Power Plant Construction Costs Continue to Fall, but Decline is Limited. December 18, 2009.

IHS Emerging Energy Research. 2010. Personal communication with Keith Hayes. June 4, 2010.

Kirkegaard, J., T. Hanemann, L. Weischer. 2010. It Should Be a Breeze: Harnessing the Potential of Open Trade and Investment Flows in the Wind Energy Industry. WP 09-14. Washington, DC: World Resources Institute. 
Martin, K. 2010. Economics of Wind 102. Presentation at AWEA's WINDPOWER 2010 Conference \& Exhibition, Dallas, Texas, May 24, 2010.

MISO. 2010. Dispatchable Intermittent Resources. Market Subcommittee Meeting. January 2010.

Musial, W., Ram, B., et al. 2010. Large-scale Offshore Wind for the United States: Technical Assessment of Barriers and Opportunities. Forthcoming. Golden, Colorado: National Renewable Energy Laboratory.

North American Electric Reliability Corporation (NERC). 2009a. 2009 Long-Term Reliability Assessment 2009-2018. October 2009.

North American Electric Reliability Corporation (NERC). 2009b. Accommodating High Levels of Variable Generation. North American Electric Reliability Corporation.

Office of the Press Secretary. 2010. Fact Sheet: \$2.3 Billion in New Clean Energy Manufacturing Tax Credits. January 8, 2010. http://www.whitehouse.gov/the-pressoffice/fact-sheet-23-billion-new-clean-energy-manufacturing-tax-credits

PacifiCorp. 2005. Technical Appendix for the 2004 Integrated Resource Plan. Portland, Oregon: PacifiCorp.

PacifiCorp. 2007. Technical Appendix for the 2007 Integrated Resource Plan. Portland, Oregon: Pacificorp.

PacifiCorp. 2009. 2008 Integrated Resource Plan: Volume 11 - Appendices. Portland, Oregon: Pacificorp.

Pfeifenberger, J., P. Fox-Penner, D. Hou. 2009. Transmission Investment Needs and Cost Allocation: New Challenges and Models. Presentation to the Federal Energy Regulatory Commission. December 1, 2009.

Piwko, R., et al. 2007. Intermittency Analysis Project Appendix B: Impact of Intermittent Generation on Operation of California Power Grid. Sacramento, California: California Energy Commission, PIER Research Development \& Demonstration Program.

Porter, K., J. Rogers. 2010. Status of Centralized Wind Power Forecasting in North America. NREL/SR-550-47853. Golden, CO: National Renewable Energy Laboratory.

Porter, K., S. Fink, C. Mudd, J. DeCesaro. 2009. Generation Interconnection Policies and Wind Power: A Discussion of Issues, Problems, and Potential Solutions. NREL/SR-550-44508. Denver, Colorado: National Renewable Energy Laboratory.

Portland General Electric (PGE). 2009. Integrated Resource Plan 2009. Portland, Oregon: Portland General Electric.

Puget Sound Energy. 2007. 2007 Integrated Resource Plan, Appendix G-Wind Integration Studies. Bellevue, Washington: Puget Sound Energy.

SCE. 2010. Southern California Edison Celebrates Milestone for a Major Renewable Transmission Project. May 4, 2010. http://www.edison.com/pressroom/pr.asp?bu $=\& y e a r=0 \& i d=7390$ 
Shiu, H., M. Milligan, B. Kirby, K. Jackson. 2006. California Renewables Portfolio Standard Renewable Generation Cost Analysis: Multi-Year Analysis Results and Recommendations. Consultant report prepared by the California Wind Energy Collaborative. Sacramento, California: California Energy Commission.

SPP. 2010. Submission of Tariff Revisions to Modify Transmission Cost Allocation Methodology. Docket No. ER10-1069-000.

Stolarski, Christopher, Raymond Wood, John Eber, Stephen Schaefer. 2010. Capital Sources for the Future. Panel discussion at AWEA's WINDPOWER 2010 Conference \& Exhibition, Dallas, Texas, May 24, 2010.

3Tier. 2010. 3TIER Releases Wind Performance Maps: Maps illustrate impact of El Niño in 2009. February 4, 2010. http://www.3tier.com/en/about/press-releases/3tier-releases-windperformance-maps/

Tonbridge. 2010. Tonbridge Power Inc. Announces 2010 First Quarter Results. May 28, 2010. http://www.marketwire.com/press-release/Tonbridge-Power-Inc-Announces-2010-FirstQuarter-Results-1268293.htm.

UBS Limited. 2010. UBS Global I/O: Global Wind Sector. UBS Investment Research. 15 March.

U.S. Court of Appeals for the Fourth Circuit. 2009. Piedmont Environmental Council v. FERC, No. 07-1651 (4th Cir. Feb. 18, 2009).

U.S. Court of Appeals for the Seventh Circuit. 2009. Illinois Commerce Commission, et al. v. FERC, Nos. 08-1306, et al. (7th Cir. Aug. 6, 2009).

Ventyx. 2010. Velocity Suite Data Product. Accessed June 15, 2010.

WAPA. 2009. Montana-Alberta Tie Limited Project, Western's first TIP Project. http://www.wapa.gov/recovery/projects.htm.

Wyden, R. 2010. U.S. Trade in Environmental Goods: Follow-Up Report to 'Major Opportunities and Challenges to U.S. Exports of Environmental Goods.' Washington, DC: United States Senate.

Zaelke, E., C. Carstensen, L. Markowitz, K. Walsh, R. Abel. 2010. Optimizing Capital in the Current Environment. Panel discussion at AWEA's WINDPOWER 2010 Conference \& Exhibition, Dallas, Texas, May 24, 2010. 


\section{Wind Energy Web Sites}

\section{U.S. Department of Energy Wind and}

\section{Water Power Program}

www.windandwater.energy.gov

\section{Wind Powering America}

www.windpoweringamerica.gov

\section{Lawrence Berkeley National Laboratory}

http://eetd.Ibl.gov/EA/EMP/re-pubs.html

\section{National Renewable Energy Laboratory \\ www.nrel.gov/wind}

\section{Sandia National Laboratories}

www.sandia.gov/wind

Pacific Northwest National Laboratory

www.pnl.gov

Lawrence Livermore National Laboratory

www.llnl.gov

\section{Oakridge National Laboratory}

www.ornl.gov

\section{Argonne National Laboratory}

www.anl.gov

Idaho National Laboratory

www.inl.gov
Ames Laboratory
www.ameslab.gov

Los Alamos National Laboratory

www.lanl.gov

\section{Savannah River National Laboratory}

http://srnl.doe.gov

\section{Brookhaven National Laboratory \\ www.bnl.gov}

\section{American Wind Energy Association \\ www.awea.org}

Database of State Incentives for Rennewables \& Efficiency

www.dsireusa.org

International Energy Agency - Wind Agreement www.ieawind.org

\section{National Wind Coordinating Collaborative www.nationalwind.org}

\section{Utility Wind Integration Group}

www.uwig.org

\section{For more information on this report, contact:}

Ryan Wiser, Lawrence Berkeley National Laboratory

510-486-5474; RHWiser@lbl.gov

Mark Bolinger, Lawrence Berkeley National Laboratory

603-795-4937; MABolinger@lbl.gov

\section{On the Cover}

The 63-MW Dry Lake Wind Power Project installed in Arizona in 2009

is the state's first utility-scale wind power project.

Prepared by the National Renewable Energy Laboratory (NREL) NREL is a national laboratory of the U.S. Department of Energy Office of Energy Efficiency and Renewable Energy Operated by the Alliance for Sustainable Energy, LLC
For more information contact: EERE Information Center 1-877-EERE-INF (1-877-337-3463) www.eere.energy.gov/informationcenter 